\author{
Juliana Jardim Barboza
}

\title{
vestígios do dizer de uma escuta (repouso e deriva na palavra)
}

\begin{abstract}
Tese apresentada ao Programa de Pós-Graduação em Artes, Área de Concentração Artes Cênicas, Linha de Pesquisa Teoria e História do Teatro, da Escola de Comunicações e Artes da Universidade de São Paulo, como exigência parcial para obtenção do Título de Doutora em Artes, sob a orientação da Prof $^{a}$. Dr ${ }^{a}$. Sílvia Fernandes da Silva Telesi.
\end{abstract}

São Paulo, SP, 2009 
Subir e descer nas próprias palavras é a vida do poeta. Subir muito alto, descer muito baixo é permitido ao poeta que une o terrestre ao aéreo. Gaston Bachelard, A poética do espaço 


\section{RESUMO}

0 texto que se segue pretende traduzir algumas possibilidades no trabalho do ator no que diz respeito à experiência a partir da palavra, como dizer vindo de um texto, originada no aprofundamento da escuta. 0 texto nasce de minha prática, iniciada formalmente em 1987, como atriz, professora de teatro, preparadora de atores e aluna, e refere-se a experiências em montagens de peças, aulas (dadas e recebidas) em universidades, estágios, workshops, oficinas, e em encontros em outros espaços nãopertencentes ao campo teatral, acontecidos principalmente nos estados de São Paulo e Rio de Janeiro, e pontualmente em outros estados brasileiros (MG, PR, SC, CE) e em outros países. Dialoga, ainda, com aquilo que nomeio teorias-moventes para as práticas, fontes teóricas nascidas de meu contato com textos de naturezas diversas, de não-ficção - de teatro e de outras áreas - e de ficção, além do contato específico com uma tradição oral, a do griot africano, que, em meu caso específico, se deu pelo encontro vivo, em duas viagens ao Mali e ao Burkina Faso, na África Ocidental, e em seis estágios realizados a partir dessa aliança.

Palavras-chave: ator, escuta, texto, dizer, repouso, deriva. 


\section{ABSTRACT}

The following text aims at translating some possibilities in the actor's work in experience with the word, as a telling coming from the text, originated in the deepening of the listening. The text is born from my practice, formally begun in 1987 , as an actress, theater teacher, actors coach and student, and refers to experiences in staging plays, classes (given and taken) in universities, internships, workshops, and in meetings at spaces not belonging to the theatrical field, mostly taking place in the states of São Paulo and Rio de Janeiro, and occasionally in other Brazilian states (MG, PR, SC, CE) and in other foreign countries. It also dialogues with what I call moving-theories into practices, theoretical sources sprung from my contact with texts of different nature, non-fictional - from theater and other areas - and fictional, in addition to the specific contact with an oral tradition, namely the African griot that, in my particular case, happened by means of living contact in two trips to West Africa, to Mali and Burkina Faso, and in six internships brought about by this alliance.

Keywords: actor, listening, text, telling, linger, derivation. 


\title{
campo sob o texto
}

\author{
palavra \\ ator \\ escuta dizer
}

práticas

técnica como des-encobrimento

texto (escrito, lido, dito)

pensamentos-corpo (teorias moventes)

intimidade, proximidade, re-colhimento

endereço (destino), distância, palavra colhida

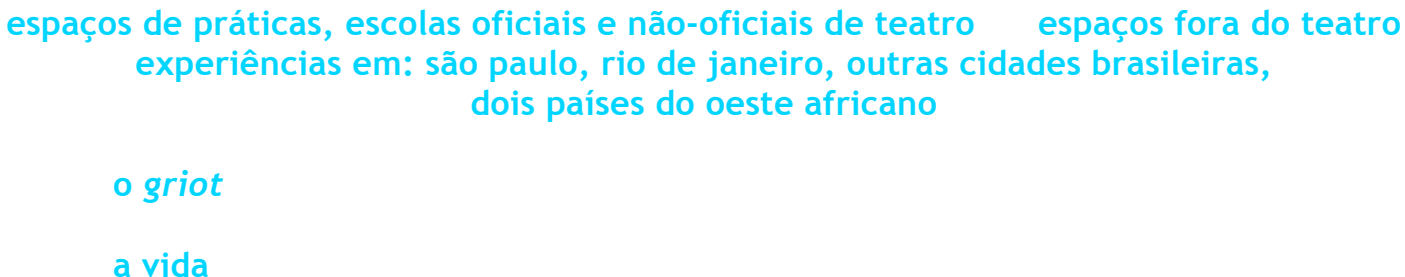

vínculos e seus contrários

aberturas e seus contrários

textos de naturezas diversas

acriançar

envelhecer

perguntas

escuridão

dúvidas

clarezas

nomadismo, mudança, impermanência

escavações do texto

insistir, morada

repouso e deriva (a partir da palavra)

palavra-viva

palavra-amortecida/anestesiada

leituras

duração (e velocidade)

l e $n$ t $t$ i d

in-tensão: reverso da intenção? (pensar o querer-dizer) sentido=direção

o 'entre'

costas como rosto, olhos para trás

o quieto

bordas da boca

poros, pele

narradores

narrativas

cuidadores

presentes-cuidadores em forma de narrativas terceiro olho

a urgência (e a calma) das etimologias

amizades (livros, professores, alunos, família, parceiros de lá e daqui) 


\section{sumário}

delimitação expandida do campo

minha posição nos sentidos deste pensar, deste escrever $\quad 15$

eu agradeço a

PERGUNTA

impressões, ações e questões na origem da pergunta

uns japoneses que nomeiam as coisas por aqui

Nome não dá: nome recebe.

SOTIGUI KOUYATÉ: espanto e encanto na aliança com um griot

ENTRE O ATOR E A PALAVRA: escuta e demora de algum silêncio

vestígios de lugares-escutantes para receber a palavra na proximidade

vestígios de escavações da palavra

vestígios do ator cuidador

vestígios de algum repouso, de alguma deriva

vestígios da relação boca-orelha da narração

vestígios de narrativas cuidadoras

vestígios de uma criação cênica

vestígios da escuta de um dizer 


\section{delimitação expandida do campo}

O que no pensamento libera e dá a pensar não é nem o método nem o tema, mas o campo, que assim se chama porque abre campos.

Martin Heidegger

Aqui repousamos sobre uma delimitação desse campo sob o texto vindo antes, que contém as palavras nomeadoras do que tem sido nosso trabalho.

O texto pretende traduzir alguma abertura de possibilidades no trabalho do ator no que diz respeito à experiência com a palavra, como dizer vindo de um texto, originada no aprofundamento da escuta. Esta escrita nasce de minha prática, iniciada formalmente em 1987, como aluna, atriz, professora de teatro, preparadora de atores, e refere-se a experiências em montagens de peças, aulas (dadas e recebidas) em universidades, estágios, workshops, oficinas e em encontros.

Os espaços em que as experiências aqui referidas vêm acontecendo são salas de ensaio de peças ou de preparações de trabalhos de grupos, espaços de formação nos quais trabalho - escolas de teatro oficiais e não-oficiais - e espaços fora da área teatral, e, ainda, fora de ambientes de 'trabalho'. Minhas experiências aconteceram em sua maioria nos estados de São Paulo e Rio de Janeiro, mas também, pontualmente, em alguns outros estados brasileiros (Ceará, Minas Gerais, Paraná, Santa Catarina). Viagens recentes a dois países da África Ocidental (Mali, 2003/04, e Burkina Faso, 2003/04 e 2007/08) também são presentes no terreno dessa escrita. Os vínculos da vida e seus contrários, os des-vínculos, também estão aqui, junto com as aberturas e seus contrários.

Escuta, aqui, é tema fundador que tentará ser definido em várias direções. Começamos por afirmar que nossa acepção vai além do que seria a definição de escuta como amplificação do 'ouvir'. Aqui, escuta tem mais afinidade com o contato concreto com nossa sensibilidade sutil, ou com a sensibilidade para as sutilezas, do que com o 
aprimoramento de nosso sistema auditivo ${ }^{1}$. Para essa trajetória são fundamentais as práticas desenvolvidas por ou para o ator, mas também experiências, exercícios e laboratórios advindos de outras áreas. Técnica, para nós, é des-encobrimento - tirar o que cobre, o que tapa, o que impede a abertura -, mediação para abrir espaços entre o ator e ele mesmo e o ator e o outro, qualquer que seja esse outro: o texto, o outro ator, o público.

Interessam-nos, como teorias moventes, o que passamos a nomear pensamentoscorpo, ou seja, uma multiplicidade de fontes teóricas nascidas de nosso contato com textos de naturezas diversas, de não-ficção - de teatro e de outras áreas - e de ficção, além do contato específico com uma tradição oral, a do griot africano, que, em nosso caso específico, se deu pelo encontro vivo, em duas viagens (ao Mali e ao Burkina Faso) e em seis estágios realizados, ou seja, não aconteceu por meio de leituras sobre o tema. Pelo contrário, todas as vezes nas quais tentei adentrar nessa seara, fui 'severamente' reprimida pelo griot que se tornou meu 'guia', Sotigui Kouyaté, sobre o qual falarei mais tarde.

Os assuntos aos quais esse estudo mais tem se dedicado na relação do ator com a palavra lida e dita são a intimidade, a proximidade, o recolhimento, o repouso sobre o texto, no aprofundamento da percepção do lugar de origem de um dizer com essas mesmas qualidades. A busca tem sido rigorosa também pela consciência do endereço para quem o ator fala, o destinatário de seu dizer, junto à clareza dessa distância (que se quer também aproximadora), e à percepção da palavra colhida no texto. Ambicionamos alguma tatilidade nessa relação múltipla, complexa e sem fim.

\footnotetext{
${ }^{1}$ Para os que desejam conexões com o tema da audição e da reeducação da escuta auditiva, recomendamos a leitura dos livros e artigos de Alfred Tomatis (1920-2001) e o contato com o Centro Tomatis, em São Paulo. Tomatis foi um médico suíço, otorrinolaringologista especialista em problemas de audição e linguagem, tendo formulado uma série de leis que constituem o Efeito ou Método Tomatis. Muitos atores europeus já receberam este treinamento auditivo.
} 
Acriançar, a partir de alguma ingenuidade, e envelhecer, a partir de alguma demora, as nossas ações em repouso sobre a palavra e, ao mesmo tempo, a disposição para a pergunta, a questão, as dúvidas, os escuros e as clarezas, têm sido, todos, nomes das minhas teimas.

Insistir no nomadismo, nas mudanças, na impermanência do ator diante da palavra, para que ele e ela mantenham-se num lugar aberto, também vem sendo movimento constante para o encontro de alguma morada nessa relação.

A palavra-viva, em oposição à palavra-mortamente-dita, percebida pelo ator, ocupa espaço constante na busca. A relação com o tempo como duração, em oposição ao tratamento do tempo como velocidade, e uma aplicação prática grande no trabalho com a $l e n t i d \tilde{a} o$, também se tornaram fundamentais na abertura para a escuta. Aqui, invertemos a relação entre ator e texto, normalmente tratada também do ponto de vista das intenções com a palavra, com o que ela 'quer dizer', 'significar', 'transmitir', para algo que poderia ser o reverso da intenção, a tensão dentro do ator e dentro da palavra, a in-tensão (tensão dentro, tensão 'entre’). Ao tirar as nuvens que nos separam da palavra de um texto, na insistência com a aproximação dele, com o desencobrimento da fala ininterrupta que nos assola, podemos abrir mais espaços e, quem sabe, termos também o público nalguma possibilidade de maior escuta e, talvez, mais perto de nós.

Aqui sentido não tem a acepção de propósito, intencionalidade, objetivo, mas é abertura para diferentes direções.

Há práticas que procuram demorar-se em algumas regiões do corpo, para lembrar-nos de alguns assuntos na relação com a palavra. As costas são tratadas como rosto, como lugar que permanece sempre olhando para trás, para nossa origem, analogamente ao contato com a origem da palavra. Além de serem solo possível para alguma quietude mais profunda no corpo do ator. O terceiro olho, o pássaro que 
observa, agir e observar(-se), entrar e sair do espaço da cena, transitar entre pessoalidade e teatralidade, são todas ações fundamentais para cuidar de si e do outro.

Pode-se ler nos textos antigos: 'Nós somos dois. $O$ pássaro que bica e $o$ pássaro que miralobserva². Um morrerá, um viverá.' Embriagados por estar dentro do tempo, preocupados em bicar, esquecemo-nos de fazer viver a parte de nós mesmos que mira/observa/olha ${ }^{3}$. Há então o perigo de existir somente dentro do tempo e em nenhum momento fora do tempo. Sentir-se mirado pela outra parte de si mesmo, aquela que está como que fora do tempo, concede a outra dimensão. Existe um Eu-Eu. 0 segundo Eu é quase virtual; não é em nós a mirada dos outros, nem o juízo; é como uma mirada imóvel: presença silenciosa, como o sol que ilumina as coisas e basta. 0 processo de cada um somente pode se completar no contexto desta presença imóvel. Eu-Eu: na experiência a dupla não aparece como separada, mas como plena, única. No caminho do Performer, percebe-se a essência durante sua osmose com o corpo, e então trabalha-se o processo desenvolvendo o Eu-Eu. O olhar/a mirada do teacher ${ }^{4}$ pode às vezes funcionar como o espelho da conexão Eu-Eu (está conexão não estando ainda traçada). Quando o enlace Eu-Eu está traçado, o teacher pode desaparecer e o Performer continuar para o corpo da essência. (...)

O Eu-Eu não quer dizer ser dividido em dois e sim ser duplo. Trata-se de ser passivo na ação e ativo no mirar/no observar (ao contrário do habitual). Passivo quer dizer ser receptivo. Ativo estar presente. Para nutrir a vida do Eu-Eu, o Performer deve desenvolver não um organismomassa, organismo de músculos, atlético, mas um organismo-canal, através do qual as forças circulem. (GROTOWSKI, 1992, pp. 77-78)

Cuidar do outro: o gesto tem muita importância em nossa prática com a escuta, com a palavra. Insisto nele para que cuidemos de manter o parceiro próximo desse lugar da des-coberta, da origem da abertura da escuta para receber o lido sem precipitação, na calma necessária à manutenção do solo de silêncio que pode fazer perdurar a percepção das sutilezas, dos espaços e de um dizer escutante. Tornamo-nos todos cuidadores de todos.

Os poros da pele são tratados - por meio de práticas - na sua etimologia: mópos (do grego póros) = ação de passar, travessia; passagem, via de comunicação; leito dum

\footnotetext{
${ }^{2}$ Optei por manter na tradução de mirar (em espanhol) os verbos mirar e observar (em português), pelo fato de a palavra mirar conservar em si algum sentido de silêncio, para nós mais evidente do que aquele contido nas palavras olhar ou observar, usadas em tradução anônima deste texto que circula em cópia mecanográfica. Também alterei várias outras palavras dessa tradução.

${ }^{3}$ Idem.

${ }^{4}$ Palavra mantida assim em espanhol, no original usado aqui.
} 
rio, leito do mar, mar; estreito, ponte, via, caminho; conduto ${ }^{5}$. A pele como abertura para a escuta plena. Aliás, as etimologias, os dicionários, os glossários e as diferentes línguas têm-nos sido absolutamente presentes no repouso sobre a palavra.

Em nosso campo ainda dedicamos tempo ao trabalho do ator como narrador, à experiência com o narrar, na percepção de que a consciência para sua relação com a palavra pode ser amplificada se ele vai além da forma diálógica, que é, ainda, a matriz mais constante e frequente da ação teatral. Lembrar-se das narrativas e dos narradores marcantes da vida. Lembrar-se de si, contar-se. Trabalhamos com as três modalidades de narrar possíveis: narrativas conhecidas somente do narrador (aqui aparecem muitas histórias pessoais, pois temos a certeza de que o outro não a conhece); narrativas conhecidas do narrador e da platéia; e narrativas desconhecidas de ambos - ator e platéia -, ou seja, as improvisações.

A considerável relevância que as experiências com o narrar têm em nossas propostas de práticas para o ator fez nascer uma maneira de apreciar o trabalho dos parceiros, em espaço de aprendizagem, ensaio ou exercício, também com a criação de narrativas. A isso nomeio 'presentes-cuidadores em forma de ficção': ao invés de falarmos uns sobre os trabalhos dos outros da maneira mais tradicional, por meio de comentários sobre o que vemos nas práticas, criamos presentes em forma de narrativas de ficção. ${ }^{6}$

No meu percurso, as amizades vividas, com os livros, com meus professores, com meus alunos, com todos os meus parceiros na vida e com minha família, não são nunca esquecidas.

\footnotetext{
${ }^{5}$ A partir de: PEREIRA, 1998, p. 513.

${ }^{6}$ Trato dessa prática nos vestígios da página 124.
} 
O olho técnico só enxerga na luz e só produz ofuscamento. É um olhoescuta que já pensa saber tudo, antes mesmo de começar a ver e a escutar o outro. 0 amigo, ao contrário, trabalha na sombra e, protegido pela ignorância, é ainda capaz de testemunhar e acolher as notícias e as indicações oriundas da constelação natal. Essa capacidade não é magia nem intuição. Ela é algo dado desde que se ocupe o lugar humano quando o humano não está esquecido nem enfiado na ilusão. A dificuldade do simples não reside em nenhuma complicação teórica, mas é um assunto existencial concernente ao poder viver na instabilidade. (PESSANHA, 2002, p. 88)

Esta escrita fez nascer uma nova relação com as práticas. Parte das experiências que proponho aos atores e alunos está aqui traduzida, analogamente, na própria experiência da escrita. Talvez isso seja melhor entendido após a leitura. Por exemplo, o modo de escrita do trecho organizado sob o título Nome não dá: nome recebe refere-se à prática descrita na página 100: os princípios da caminhada traduzidos naqueles vestígios foram retomados como orientação à minha escrita. Porém, aqui, com foco naquilo que elegi como tema principal para o capítulo: retomar a origem de minha relação com a palavra escrita, com meus olhos para trás, além de não perder a conexão com a criança na cabeça, a partir de algum recolhimento, sem paradas e sem me esquecer dos mortos debaixo de meus pés. Os mesmos princípios da prática cênica guiaram a prática da escrita. 


\section{Minha posição nos sentidos deste pensar, deste escrever}

\section{(esclarecimentos sussurrados em seu ouvido)}

Perco (?) muito tempo a buscar sentido para esse escrever, derivando, não com pouca angústia e irritação, para perguntas sobre a tentativa de traduzir (impossibilidade originária), em palavra escrita, algumas práticas e experiências vividas. Mas a possibilidade de nomear isso com a palavra 'vestígio' traz alguma calma ao gesto. Ao menos, é um pacto entre nós.

Talvez eu queira, com essa tradução (insisto: impossibilidade originária), ser mensageira de alguma corporeidade já vivida com tamanha intensidade (aumentada pela calma e pelo silêncio presentes nas experiências) na minha relação com a palavra - lida, dita, escutada, vista, pega, escapada -, pelas alterações que elas e-vocaram em meu corpo...

Esse trabalho é para insistir... talvez lembrar. Pois as práticas teimam.

“Teimar quer dizer, em suma, manter ao revés e contra tudo a força de uma deriva e de uma espera." (BARTHES, s/d, p. 27)

Essa escrita não quer assegurar nada, não fala a partir de nenhuma garantia (do tipo 'fiz, e tudo o que deu certo está aqui para ser ensinado'), assim como a prática na qual ela nasce.

Há uma idade em que se ensina o que se sabe; mas vem em seguida outra, em que se ensina o que não se sabe: isso se chama pesquisar. Vem talvez agora a idade de uma outra experiência, a de desaprender, de deixar trabalhar o remanejamento imprevisível que o esquecimento impõe à sedimentação dos saberes, das culturas, das crenças que atravessamos. Essa experiência tem, creio eu, um nome ilustre e fora de moda, que ousarei tomar aqui sem complexo, na própria encruzilhada de sua etimologia: Sapientia: nenhum poder, um pouco de saber, um pouco de sabedoria, e o máximo de sabor possível. (BARTHES, s/d, p. 46) 
No vislumbre de algum sabor futuro, sei que estou na idade de 'ensinar' (?) o que não sei, vindo de uma em que também não sabia. 
“Não queremos, porém ir a lugar nenhum. Queremos ao menos uma vez chegar no lugar em que já estamos." (HEIDEGGER, 2003, p. 8.) 
Sílvia Fernandes, com meu agradecimento maior pelo presente de sua proximidade nesta escrita. Foram seu afeto, seu rigor e sua delicadeza que me guiaram, com insistência, para que eu escutasse, sempre, a minha própria voz.

Minha mãe, meu pai, meus irmãos (Maria Elisa, Ruy, Saulo, André, Carolina), pelas palavras com corpo nas coisas escritas entre-nós, em bilhetes, cartas, blocos. Pela grande quantidade de livros e revistas de todo o tipo naquelas estantes, pelas casas gostosas que me ocuparam a metade da vida, pelas mudanças todas e pelos 21 anos de nossa existência em comunhão, algumas vezes dramática, mas em muitas outras, cheia de humor...

Minha mãe, ainda, pelo gesto intuitivo que, com sua mão em meu peito, cuidou para que eu não me afastasse da minha vocalidade originária. Espero manter-me até o fim neste traço, começado por você.

Meus quatro avós. Nair e Jardim, pela nobreza e calma com o dizer das coisas sérias 'do viver', pela graça ingênua, pela sensualidade, também nas palavras, sempre à flor da pele. Ivone e Ruy, pela sagacidade com as palavras, pelo humor escancarado, pelas músicas cantadas e pelo que elas me contavam.

Sotigui Kouyaté, por um exercício precioso ensinado em sussurro no banco de trás de um carro, pelo convite à viagem num restaurante, por sua engraçadíssima imitação de bêbado, pelo agradecimento manifestado numa tarde de rainha em Bamako em 2003, por me 'deixar ir' a Ouahabou em 2008, por todas as vezes que me deixou ver o trânsito suave para a teatralidade em seu corpo. Tenho a impressão de que nenhuma palavra poderá jamais nomear o que venho recebendo a partir de você, durante esse primeiro setênio de nosso encontro. Como você mesmo diz, ainda estamos no "début du commencement".

Janô (Antonio Januzzeli), pelo que me ensina, pelo que aprendemos juntos, por revelar tamanha confiança. E lá se vão dezenove anos...

Alexandre Valverde, pelo amor que nos aconteceu em 1991 (você, aluno, com 13 anos; eu, professora, com 24); por escutar e me dizer, 15 anos depois, que eu teria com Martin Heidegger o que se chama encontro; e pelo choro com sua criança que apontei atrás de você, quando líamos juntos o alemão, num parque perto da casa que dividimos, durante 5 meses, em 2008.

Todos os participantes daquele encontro em 12 de abril de 2003 com Madrugada na Casa das Palmeiras. Na continuação da intensidade da experiência, agradeço aos parceiros sóciosfundadores do Espaço Artaud, pelo convite mais tocante recebido em minha vida... que não pude aceitar.

Dani e André, pelo Edu, pela Bê e por quem vem chegando aí.

Habib Dembélé, por um gracioso erro sobre as verdades em 2004, pelo charme absoluto em 2006, pelos presentes preciosos enviados em 2008 e por partilhar a séria brincadeira que me faz viver em sua cena.

Cassiano Sydow Quilici e Maria Thaís Lima Santos, pela dedicação a este trabalho, revelada na banca de meu Exame de Qualificação em novembro de 2007.

Mônica Malheiros, Maria Ceccato, Paulo Barcellos, Vicente Concilio, Emílio Terron, César Gouvêa, Márcio Ballas, Nando Bolognesi, Vera Abbud, Allan Benatti, Paola Musatti, Rhena de Faria, Paulo Federal, Eugenio la Salvia, Luciana Lopes, Marco Gonçalves, Cláudio Thebas, Maria Thais Lima Santos e funcionários do TUSP em 2007 pelo convite para a mostra Experimentos, 
funcionários do CAC-ECA-USP desde 1990, funcionários da EAD-ECA-USP em 2006, Melissa Guimarães, Marcelo Pretto, Juliano Garcia Pessanha, Monsieurs Ric e Simi e todos os participantes do Retiro de Palhaço de fevereiro de 1996, família Konate e todas as crianças de Ouahabou, Seydou Konate, Ladji Konate, Cheick Oumar Kouyaté (Tintin), Bakary Kouyaté, Ibrahim Kouyaté, Esther Kouyaté, Isabelle Genlis, Soussaba Kouyaté, Tagaré Kouyaté, Magan Kouyaté (em memória), Adiara Konate, Hassane Kassi Kouyaté, Khadija Kouyaté, Abdoulai Ouologuem, Badou Ouologuem, à menina de Bamako que me deu um coração, a todos os atores e trabalhadores do estágio de Sotigui em Ouagadougou em janeiro de 2008, a generosidade, a abertura e o cuidado recebidos das pessoas que conheci em 2003/04 e 2007/08 nas cidades ou vilarejos de Bamako, Bobo-Dioulasso, Ouahabou, Ouagadougou, Nasso e Pa, Ana Paula e Matthew, João Carlos Artigos, Flávia Berton, Shirley Brito, Regina Oliveira, Angélica Gomes, Márcio Libar, Rubens Jardim, Luiz Guilherme Leitão Vieira, Flávia Mellman, Otávio Dantas, Dedé Pacheco, Cristiane Paoli-Quito, Marcelo Gomes, Magali Biff, Daniela Duarte, Celso Alves Cruz, Selma Pellizon, Auber Betinelli, Marcelo Romanholi, Élida Marques, Adriana Osório, Giulia Mendonça, Adriana Fortes, Sérgio Rizzo, Paulino Dias, Juliana Porto, Luê Prado, Lívia Piccolo, Ana Julia Marko, Diogo Spinelli, Welington Andrade, Renato Theobaldo (por uma Alice com Jardim, que pediu, em 2000, um ator-cuidador), Nichan Dichtchekenian, Amauri Falsetti e Cia. Paidéia de Teatro, Ana Achcar, Isaac Bernat, João Miguel Leonelli, Bia Jardim, Tieza Tissi, Amadeu Amaral, Carolina Troiano, Luciana Guidorzi, Bias Arrudão, René Piazentin, Gustavo Vieira, Cia. Livre pelo encontro no qual tornei pública alguma voz de parte do que aqui está.

Maria Lúcia Pupo, que fez o primeiro convite para eu me escutar narrando a viagem de 2003, e leu o primeiro ensaio de escrita de meus temas, na forma da monografia $A$ palavra com vida.

Beth Lopes, Cristiane Paoli-Quito, Chico Medeiros, Hélio Cícero, Luiz Damasceno, Márcio Aurélio, Myrian Muniz (em memória), Ricardo Puccetti, por nos receberem em suas casas e partilharem todas aquelas preciosidades sobre suas vidas e sobre o ator, em 1999 e 2000.

Todos os participantes e amigos que estiveram nas oficinas e nas conferências que ajudaram a trazer Sotigui Kouyaté para São Paulo em 2003 e 2004. O SESC, que acolheu e custeou a oficina e a conferência de 2006, o Anjos do Picadeiro do Teatro de Anônimo, e Andrea Caruso.

MinC - Programa de Intercâmbio e Difusão Cultural, pela passagem para a viagem ao Burkina Faso em 2007/08.

Todos os meus familiares e amigos que me apoiaram com a passagem e os gastos da viagem de 2003/04.

Todos os atores e alunos (atores e não-atores) com os quais tenho trabalhado desde 1987, pois creio que temos conseguido, juntos, nunca tratar nosso trabalho a partir das 'oficialidades'. Especialmente, pelo tempo oferecido pela vida e pela confiança vivida nos lugares para onde nos levamos, agradeço: toda a turma formada em 2006 na Universidade São Judas Tadeu e Miguel Prata, Luiz Paulo Pimentel, Ighor Wallace, Caio Paduan, Juliana Rodrigues, Daniel Mazarollo. 
esta é uma escritura nascida de experiências práticas dedicadas ao ator - muitas das quais foram vividas com meus professores, diretores, atores, amigos, gente que se dedica a isso de algum modo - e nascidas de experiências acontecidas em outras áreas, fora do teatro.

várias práticas que me foram oferecidas eu transformei. há ainda outras que ousei e ouso inventar (ou 'penso' que invento), para cuidar de problemas meus diante das dificuldades de relação com a palavra lida e dita em cena, para cuidar de meus alunos e dos atores com quem tenho trabalhado, nos lugares (cada vez mais misturados) de professora e atriz.

esta escritura nasce também das poucas leituras (dos terrenos da prosa, da poesia, da dramaturgia, de teorias não-teatrais e teatrais) que fiz até hoje e que, por total incapacidade de manter as coisas separadas - cada uma no seu campo -, atravessam cotidianamente os assuntos de meu trabalho e são frequentemente levadas para os espaços em que experimentamos as práticas.

e, ainda, para não ser leviana: esta escritura está absolutamente contaminada pelas relações humanas de minha convivência cotidiana, por conversas, tanto as fundas quanto as mais banais, por acasos, por pedaços de coisas escutadas, ensinadas, aprendidas, escapadas, por insistências e, claro, por desistências. 
pro Eduardo, que me oferece repouso, deriva e o concreto aprendizado do simples.

Gostaria pois que a fala e a escuta que aqui se trançarão fossem semelhantes às idas $e$ vindas de uma criança que brinca em torno da mãe, dela se afasta e depois volta, para trazer-lhe uma pedrinha, um fiozinho de lã, desenhando assim ao redor de um centro calmo toda uma área de jogo, no interior da qual a pedrinha ou a lã importam finalmente menos do que o dom cheio de zelo que deles se faz. 
“O homem fala. Falamos quando acordados e em sonho. Falamos continuamente. Falamos mesmo quando não deixamos soar nenhuma palavra. Falamos quando ouvimos e lemos. Falamos igualmente quando não ouvimos e não lemos e, ao invés, realizamos um trabalho ou ficamos à toa. Falamos sempre de um jeito ou de outro. Falamos porque falar nos é natural. Falar não provém de uma vontade especial. Costuma-se dizer que por natureza o homem possui linguagem. Guarda-se a concepção de que, à diferença da planta e do animal, o homem é ser vivo dotado de linguagem. Essa definição não diz apenas que, dentre muitas outras faculdades, o homem também possui a de falar. Nela se diz que a linguagem é o que faculta o homem a ser o ser vivo que ele é enquanto homem. Enquanto aquele que fala, o homem é: homem. Essas palavras são de Wilhelm von Humboldt. Mas ainda resta pensar o que se chama assim: o homem." (HEIDEGGER, 2003, p. 7) 


\section{PERGUNTA}

\section{(crise> agravamento súbito de um estado crônico ${ }^{7}$ )}

Hoje, tento escutar e servir ao outro para que escute.

Tento.

Espero.

Nos lugares onde tenho trabalhado, vivido, as pessoas quase não se escutam (mais). E o teatro, o estudo da teatralidade, justamente por sua radicalidade com a concentração (intensa) das coisas todas em ex-posição, parece escancarar o problema, no seu permitir 'ver mais'8. Não se trata de um ataque esta afirmação da falta de escuta, mas tem sido uma das meias-luas da verdade (a minha e de alguns companheiros), para encontrar outras metades (a sua), para, assim, quem sabe, celebrarmos na contemplação de uma terceira, a lua cheia 9 .

A pergunta: é possível, para o ator, aproximar-se, com alguma intimidade, da palavra de um terceiro (o autor de um texto) a partir de um aprofundamento da escuta como consciência serena das sutilezas, da quietude, do silêncio, dos espaços entre as coisas - e, ainda por cima, não perder essa intimidade quando está com o público?

\footnotetext{
7 FERREIRA, 1986. p. 500.

${ }^{8}$ Ver página 36, trecho sobre o personagem Seymour Glass.

${ }^{9}$ Citação livre a partir de BÂ, 1980.
} 


\section{Impressões, ações e questões na origem da pergunta:}

Nas duas últimas décadas, tenho visto no Brasil corpos muito vivos em cena e, em oposição, palavras ditas sem proximidade alguma com o corpo do ator que a diz ali. Escuto palavras-mortas, o que revela também alguma anestesia nos corpos. Do incômodo nascido da percepção dessa cisão, considero algumas questões sobre possíveis correspondências entre o trabalho do corpo - que vem avançando enormemente nas práticas atorais, entre nós, desde os anos 60 - e o trabalho com a palavra. Acredito que a mesma plenitude que vejo em cena alcançada pelos corpos dos atores, nas relações entre presença e distância, pode ser alcançada com a palavra, na relação com o texto dito em cena, e alguma integração poderia enterrar a tal cisão. ${ }^{10}$ Muitos já percebemos quase tatilmente a escuta sutil, que guarda quietude, silêncio, pois só assim é escuta. A palavra dita pelo ator a partir dessa escuta pode nos trazer a sensação de que, ao irmos ao teatro, partilhamos juntos uma experiência ${ }^{11}$ ? Penso, aqui, num dizer do ator mais conectado com a experiência que o fez nascer (as leituras do texto, os primeiros trânsitos, o receber das palavras) e não somente com a informação que ele transmite na superfície das palavras ali reunidas. ${ }^{12} \mathrm{O}$ ator esquece-se de si como "condutor do texto ao visível"?

O ator é a fonte da teatralidade. Ele é o ponto de passagem da palavra para o corpo, o lugar de irrupção, de origem da palavra no espaço visível da cena. É nisto que a atividade do ator participa muito essencialmente do pôr/em/cena como coração da produção do teatro. A atuação é exatamente a atividade que conduz do texto ao visível. (GUÉNOUN, 2003, p. 55)

\footnotetext{
10 “O ator só encontra o caminho quando percebe que a presença não se opõe à distância. Distância é o compromisso com a significação total; presença é o compromisso total com o momento vivo; as duas caminham juntas". (BROOK, 1994a, p.32)

${ }^{11}$ Não existe experiência coletiva, "a" experiência acontece sempre de modo singular. Falo de uma sensação, de uma impressão de coletivo, de um encontro.

12 A pergunta é contaminada pela nostalgia de Walter Benjamim, expressa em seus textos “Experiência e pobreza” e "O narrador", e pela noção de experiência usada por Martin Heidegger em seu A caminho da linguagem, todos textos que serão retomados ao longo do trabalho.
} 
Dessas impressões algumas questões surgiram como origem de nossa pergunta principal:

Será possível escutar a partir de algum silêncio também a palavra do texto, para que a palavra proferida em cena (o dizer) tenha origem nesse silêncio e destino orientado por ele? $\mathrm{O}$ ator, após encontrar intimidade com a palavra que diz - a do autor, tornada sua -, pode, ao mesmo tempo, manter-se em relação viva com o outro (seus parceiros, os outros atores e o público)?

$>$ Quais as práticas que permitem tornar visível a escuta para o ator?

> As práticas do ator como narrador podem nos ajudar? A prática com o 'contar' colabora no caminho de aproximação da palavra? De que maneira ela pode aprofundar a intimidade do ator com a palavra que profere, ou seja, abrir os espaços 'entre'?

$>$ Práticas que (acho que) invento e a deglutição de práticas que me foram ensinadas podem servir a essa escuta ambicionada na relação com a palavra? Falo de uma escuta quase 'de bicho'.

> Porque ainda há fronteira, separação nas práticas com o corpo e com a palavra, se as palavras são ditas pelo corpo do ator? 
“A questão não é: Quanto você vai extrair dele? Nem é: Quanto você vai inverter nele? Mas sim: Quão imediatamente você vai dizer Sim a qualquer imprevisibilidade, mesmo quando o que acontece parece não ter relação com o que se pensou que era o compromisso da gente?" (CAGE, 1985, p. 113.) "Conferência sobre o compromisso". Feita em 56 cartões, 28 com números, de segundos e 28 com textos, gerando um "papo de 20 minutos', foi escrita para o Simpósio Beta, da Wesleyan University, em fevereiro de 1961, quando ele era membro da comunidade acadêmica.) 


\section{uns japoneses que nomeiam as coisas por aqui ${ }^{13}$}

\section{A teoria e a prática}

“Como explica o filósofo japonês Yasuo Yuasa, no Japão e na China parte-se de uma suposição de que a relação corpo-mente muda através do treinamento do corpo, o que se processa pela cultura (shugyô) e a formação (keikô) propriamente dita. É apenas depois de adotar esse ponto de vista experiencial que se pode perguntar qual é a relação entre corpo e mente. Ou seja, este debate nunca pode ser restrito a uma especulação exclusivamente teórica. Ele se origina em uma experiência prática, vivida (taiken) que implica num continuum mente-corpo em um sujeito e em seus trâmites com o ambiente. A teoria precisa ser necessariamente uma reflexão da experiência vivida, porque ela se organiza durante a ação."

É assim que tem me acontecido a teoria.

\section{0 entre}

“Além disso, o filósofo chama a atenção para a obra de Tetsurô Watsuji (1889-1960), outro importante filósofo japonês que estudará o corpo, esclarecendo que para investigar a idéia de ser humano, precisamos antes de mais nada prestar atenção no entre (aidagara) no qual as pessoas se localizam. Este 'entre’ são os vários relacionamentos de nossa vida e é justamente esta rede de relações que parece prover a humanidade com significados sociais. (...) A própria palavra para pessoa, em japonês (ningen), é composta por dois caracteres, o primeiro significa 'pessoa ou homem' e o segundo 'espaço ou entre'. Este 'entre' significa, no sentido físico, uma distância espacial separando uma coisa em relação à outra. Existir no espaço é o significado primário da existência humana e o ‘entre' seria a extensão de um espaço corporificado (shutaiteki)."

${ }^{13}$ Todo o trecho entre as aspas nesta página foi retirado do livro GREINER, 2005, pp. 22-23. 


\section{Nome não dá: nome recebe.}

É primeiro construir sua casa para depois viver nela ou primeiro viver para depois construir sua casa? ${ }^{14}$

“Nomear não é distribuir títulos, não é atribuir palavras. Nomear é evocar para a
palavra. Nomear evoca. Nomear aproxima o que se evoca." (HEIDEGGER, 2003, p.

Nome não dá: nome recebe.

A frase de Guimarães Rosa, em sua demora sobre o nome em Grande sertão: veredas, me falou, quando lida pela primeira vez, sobre uma escuta possível de acontecer no próprio n-o-m-e-a-r, fala de homem ser atravessado pelo nomear e quem nomeia não é o homem nem nenhum dizente, mas nome é recebido pela presença que é homem ${ }^{15}$, que antevê o ser (pre-sença) e recebe, e o próprio receber já é o nomear.

Sou Juliana Jardim Barboza, nasci no dia 3 de outubro de 1967, e vivi até hoje, dia 26 de maio de 2009, aproximadamente 41 anos, 7 meses e 23 dias. Nasci na Maternidade São Paulo, e fomos morar, os três mais um tio, na rua Maria Antônia. Depois mudamos para a avenida Nove de Julho, onde moramos em uma casa da família materna e no apartamento de meus avós paternos, e já éramos cinco quando estávamos na rua Valois de Castro. Mudamos, dois anos depois, para Londrina, cidade do Paraná onde ficamos também por 2 anos, sendo que eu em duas casas distintas. Na volta para São Paulo, em 1976, já éramos seis, e tivemos uma longa temporada no bairro do Brooklin: ruas Pascoal Paes, Tacoma, Roque Petrella e Indiana. Separação dos pais e um tempo

\footnotetext{
${ }^{14}$ Pergunta nascida de minha leitura da descrição do molusco feita por Paul Valéry em Les Merveilles de la Mer. Les Coquillages, citada por BACHELARD, 1993. p. 118.

${ }^{15}$ A partir de Martin Heidegger.
} 
sem casa me fizeram morar parte na avenida Moaci, casa de um namorado, e parte em outras casas, de amigos e familiares. Volta ao Brooklin, rua Louisiana. Dali para a rua Peixoto Gomide, onde moramos em dois apartamentos diferentes em um mesmo edifício. Então fui morar, já só, na rua Paim, depois na Herculano de Freitas, depois na alameda Itu, e, a seguir, um curto período na rua Alagoas, e novamente mudei-me para outro apartamento na rua Herculano de Freitas, no mesmo prédio anterior. E, dali, para Botafogo, no Rio de Janeiro, por três anos. O retorno a São Paulo me levou à rua Madalena e um roubo, lá, me trouxe ao endereço no qual escrevo agora. Foram 22 endereços, e, calculo, 25 mudanças. Talvez derive daí meu encantamento visível pelo 'fora de lugar', minha excitação ao ver o outro 'em mudança', morando em diferentes estados, seja quando falo do trabalho do ator, seja quando estou diante de qualquer pessoa. E, talvez, tenha nascido aí, também e paradoxalmente, a minha enorme vontade de repouso, de habitar um mesmo lugar para o resto da vida.

Ocupar a casa. O texto, que se configura aqui sob o nome de tese de doutoramento, provavelmente é uma das tentativas de localizar o meu terreno, possível solo da casa sonhada. 
"Tudo o que forma os bosques, os rios ou o ar Tem lugar entre as paredes que crêem fechar um quarto

Vinde, cavaleiros que atravessais os mares,

Só tenho o teto do céu, há lugar para vós.

(...) Os grandes sonhadores confessam, como Supervielle, a intimidade do mundo, mas aprenderam essa intimidade meditando a casa."

Nos endereços vividos, o que pode trazer a origem das práticas às quais tenho me dedicado, e do nomear que empreendo com a presente escrita, é minha profunda relação corpórea, familiar e cotidiana com a palavra lida. Relação percebida pelos arrebatamentos, levitações, gozos e pungências desfrutados ao ler algumas coisas que me foram oferecidas. E, além do que era vivido, a percepção imediata ou a clareza límpida com que as conexões aconteciam e nqua n to a con te c i a m, pois eram realmente experienciadas. Creio que o que se dava ali era o início da consciência da minha escuta, de que eu me percebia em estado de alteração enquanto a experiência me atravessava.

Em casa nos comunicávamos muito por meio de bilhetes e cartas. Líamo-nos (literalmente) no cotidiano, desde informações do tipo 'este iogurte é da Carolina' ou 'esses brigadeiros não devem ser comidos, pois serão levados para o aniversário de uma amiga minha de classe', até grandes notícias foram (e ainda são) enviadas por escrito. Partilhei a 'perda da virgindade' deixando uma carta sob o travesseiro do pai, para ser encontrada no retorno de uma festa. Minha irmã contou-me sobre a descoberta do amor em uma carta deixada na portaria do prédio onde eu morava. Os relatos recentes de um grande problema familiar aconteceram com trocas de emails, de uma vivacidade visível.

Pai jornalista, irmãos e mãe todos muito vinculados à escrita por meio de palavras vivas, ecos de um tio poeta (do movimento Catequese Poética), o primeiro (e mais 
duradouro) amor nascido de enorme enamoramento pelas palavras, que misturava nossas vidas e literaturas que nos apaixonavam, e a trajetória de experiências com leituras relatadas a seguir - nutrem todo o terreno que é solo de minha escritura.

Entre os anos de 1985 e 1987 li alguns livros que agora retornam com certo vigor. Dois deles são livros de Roland Barthes, A câmara clara, nota sobre a fotografia, lido em junho de 1986, e Aula, lido mais tarde, em 1987. No primeiro - na realidade seu último livro -, Barthes estuda algumas fotografias e se coloca como mediador entre leitor e foto. Brincando com o nome de câmara escura (máquina fotográfica), coloca-nos, os que olhamos para a foto, no lugar da lucidez, da câmara clara, pois, ao invés de submetermos o espetáculo da fotografia "ao código civilizado" podemos "afrontar nela o despertar da intratável realidade". Barthes pergunta à foto o que ela é em si, no que chama um desejo 'ontológico' nessa relação. Procura o caminho das classificações, mas a Fotografia resiste, é inclassificável. Olha para o irrepetível capturado pela imagem fotográfica, aquilo que se repete mecanicamente, mas jamais existencialmente, e reconhece que na foto o "referente adere": não vemos a foto em si, mas o referente dela. E nega os comentários sociológicos sobre as fotos, deseja-se "selvagem, sem cultura". Até que percebe:

\begin{abstract}
eu dava testemunho da única coisa segura que existia em mim (por mais ingênua que fosse): a resistência apaixonada a qualquer sistema redutor. Pois toda vez que, tendo recorrido um pouco a algum, sentia uma linguagem adquirir consistência, e assim resvalar para a redução e a reprimenda, eu a abandonava tranquilamente e procurava em outra parte: punha-me a falar de outro modo. Mais valia, de uma vez por todas, transformar em razão minha declaração de singularidade e tentar fazer da 'antiga soberania do eu' (Nietzsche) um princípio heurístico. Resolvi tomar como ponto de partida de minha busca apenas algumas fotos, aquelas que eu estava certo de que existiam para mim. Nada a ver com um corpus: somente alguns corpos. (BARTHES, 1984, p.18)
\end{abstract}

Esse foi o primeiro livro 'teórico' que li e gerou meu primeiro trabalho acadêmico realizado para a disciplina Semiologia, do curso de Letras-Português, também em 1986, em minha primeira tentativa de graduação: um trabalho que usava as ideias de Barthes 
contidas em A câmara clara para estudar as fotografias de uma revista, sobre a cultura soviética, chamada Em Foco, publicada no Brasil à época.

A experiência de leitura de $A$ câmara clara fez retornar três experiências anteriores que haviam provocado arrebatamentos jamais esquecidos.

A primeira delas, acontecida na infância, aos 8 anos, foi a leitura do livro $A$ bolsa amarela, de Lygia Bojunga, a mais antiga memória de experiência física com a palavra lida. Eu tinha saudade do livro, saudade das páginas, saudade do 'jeito' como ele era escrito, em narrativas e cartas, saudade das 'pessoas' que estavam ali, saudade de uma autora sem rosto que sustentava tudo aquilo.

A outra, aos 18 anos, foi a leitura do conto "Um dia ideal para os peixes-banana", de Jerome David Salinger ${ }^{16}$. Lera antes outros quatro livros do autor, sendo que em três deles ele conta histórias da família Glass: Seymour, uma introdução, Pra cima com a viga, moçada (ou Carpinteiros, levantem alto a cumeeira) e Franny e Zooey. Sua obra mais famosa, $O$ apanhador no campo de centeio, era então, para mim, um livro 'chato'. A família Glass me intrigava, mas acima de tudo eu 'idolatrava' seu protagonista (ao menos, era-o para mim), Seymour Glass. O conto "Um dia ideal para os peixes-banana”, lido no endereço da rua Indiana, na casa na qual moramos por mais tempo, trouxe a pungência maior, acontecida em dois momentos precisos, mas com preparações muito bem distribuídas ao longo de toda a leitura. Pelos outros livros, sabia que esse Seymour Glass tinha se matado; sabia também que ele era meio doido, e adorava-o principalmente por um dia ter jogado um objeto na cabeça da irmã pequena por não suportar sua beleza, após alguns segundos de contemplação. Esse arroubo me atraía enlouquecidamente, em minha máxima manifestação adolescente. Em “Um dia ideal para os peixes-banana", quando a menina Sybil, com quem Seymour está no mar, chama-o de "Viu mais vidro" - e a nota do tradutor no pé da página diz "No original, see

\footnotetext{
${ }^{16}$ SALINGER, 1969, p.7.
} 
more glass, cuja pronúncia é idêntica à do nome do personagem Seymour Glass" - quase tive um ataque cardíaco (é a adolescente quem fala aqui). O coração disparou e me atacou. Fiquei transtornada com o 'ver mais' nomeando Seymour... Ele é como alguém que vê mais, mas é cheio de mistério, alguém que se encobria e des-encobria todo o tempo para mim... Novamente, ao final do conto, uma página e meia depois de explicar à menina o que são os peixes-banana (trecho que abriu muito decisivamente espaço para o arroubo seguinte), tenho um novo disparo ao ler "apontou a pistola e deu um tiro em sua própria têmpora direita." O conto acaba aqui.

A terceira experiência lembrada, que dialoga com minha leitura de $A$ câmara clara, não foi uma leitura de palavras somente. O livro Os olhos do gato, com desenhos de Moebius e roteiro de Alejandro Jodorowski, narra uma história de modo cinematográfico, em campo e contracampo: um morador de uma torre em ruínas aparece de costas enquanto uma ave parte. O homem ouve o som dos passos de um gato e pede à ave que mergulhe depressa. Durante 38 páginas, o contracampo é mostrado nas páginas à esquerda e trata-se sempre do desenho do homem de costas. A ave retira os olhos do gato e leva-os ao homem, que os pega somente no 'take' da página 45. $\mathrm{Na}$ página 49, o homem coloca os olhos do gato no espaço de seus olhos, que, então, notamos inexistentes, e diz: “É maravilhoso. Brincar de ver.” O livro termina com a imagem mesma em campo e contracampo da ave partindo novamente e o homem dizendo: "Na próxima vez traga-me os olhos de uma criança.” Quando terminei de lerver (talvez, assistir a) Os olhos do gato senti um calor denso misturado à clara impressão de um líquido interno jorrar, subir pelos pés, percorrer o corpo todo e sair pelo topo da cabeça. Curta, clara, intensa e imediata sensação. Como se fosse possível uma flecha atingir-me como alvo, meu corpo todo como alvo de sua ponta. Impulso recebido do livro por palavra e imagem, configurado em ação física imediatamente e percebido 
impregnação na memória. E sabia, com precisão, o que me provocava isso: a frase final.

Minha aventura com esses livros, minha enorme atração pela palavra lida, pelos vigores físicos experienciados, pela surpresa e pelo arrebatamento vividos em cada contato, facilitaram o caminho para compreender e viver junto com o que Barthes chama de studium e de punctum. O studium é

a aplicação a uma coisa, o gosto por alguém, uma espécie de investimento geral, ardoroso, é verdade, mas sem acuidade particular. É pelo studium que me interesso por muitas fotografias, quer as receba como testemunhos políticos, quer as aprecie como bons quadros históricos: pois é culturalmente (essa conotação está presente no studium) que participo das figuras, das caras, dos gestos, dos cenários, das ações. (BARTHES, 1984, p. 45)

Mas um segundo elemento vem "quebrar (ou escandir) o studium”. É um elemento que Barthes não vai buscar, mas, ao contrário,

é ele que parte da cena, como uma flecha, e vem me transpassar. Em latim existe uma palavra para designar essa ferida, essa picada, essa marca feita por um instrumento pontudo; essa palavra me serviria em especial na medida em que remete também à idéia de pontuação e em que as fotos de que falo, são, de fato, como que pontuadas, às vezes mesmo mosqueadas, com esses pontos sensíveis; essas marcas, essas feridas são precisamente pontos. A esse segundo elemento que vem contrariar o studium chamarei então punctum; pois punctum é também picada, pequeno buraco, pequena mancha, pequeno corte - e também lance de dados. 0 punctum de uma foto é esse acaso que, nela, me punge (mas também me mortifica, me fere). (BARTHES, 1984, p. 45)

A palavra como autora da flechada. A palavra como provocadora da pungência. A palavra como alguma coisa que dá o estalo. A palavra que convida ao 'ver mais vidro'. A palavra que agrega em seu solo alguma imagem e que gera um dizer escutante. Um dizer escutante que consente a abertura de tudo que pode haver entre dizente e si-mesmo, 
entre dizente e texto, entre aquele que diz e aquele que escuta. A escuta da palavra que propicia aproximação sempre (e, talvez, por isso mesmo) e-vocando ${ }^{17}$ espaços.

Tenho saudade. Saudade desse lugar da palavra que um dia me flechou. É o que move o trabalho aqui transmutado em escritura. Saudade de um lugar no qual origem e destino moravam na palavra, pois a palavra era nascida de uma origem e tinha, desde seu nascimento (acontecido enquanto eu a lia), um destino guiado por sua origem: sensação de conexão redonda, certeza de que era para mim e ao sê-lo tornava-se, então, minha. Nesse lugar, a palavra é carne, é corpo, é sangue. Mas não leia drama nessas palavras que escolho. Ao contrário, o que permite a intensidade da palavra é justamente a força-calma ${ }^{18}$ do encontro entre nós. Ela é presença e provê alimento ao homem que a escuta e que é, ele mesmo, o que a diz (ela virou sua agora que a flecha atravessou o papel). E essa escuta é o atravessar de um dizer e o dizer é também o que atravessa e escuta, ele mesmo. Só que esse atravessamento também acontece sem drama, ele é quieto. 0 dizer é quieto, pois só no silêncio (sob a palavra) há escuta. Nesse lugar, até o grito mais alto tem um quieto que o sustenta e é graças a ele que é possível ser imenso e íntimo: o homem que diz.

Além das experiências das leituras descritas anteriormente, fui presenteada com outros vestígios mais e menos próximos desse lugar. E são eles, todos juntos, que movem a procura.

Um deles, certamente o mais incisivo, é o encontro com o griot ${ }^{19}$ e ator africano Sotigui Kouyaté, que, ao oferecer o encantador e espantoso contato com sua tradição,

\footnotetext{
17 "Evocar no sentido originário de deixar vir a intimidade de mundo e coisa é propriamente chamar." (HEIDEGGER, 1995, p. 22)

${ }^{18}$ Expressão que conheci com Sotigui Kouyaté.

19 “Griot: corporação profissional compreendendo músicos, cantores e sábios genealogistas itinerantes ligados a algumas famílias cuja história cantam e celebram. Podem também ser simples cortesãos. Como não existe em português um termo equivalente para designar estas pessoas e este tipo de atividade, foi conservado o termo original." (BÂ, 2003, p. 13)
} 
desde 2002 me desperta, enquanto afirma, insiste e reverbera em muito do que aqui está.

Dois outros foram os encontros com as máscaras do Palhaço, iniciado em 1992, e do Bufão, em 1998, a partir dos quais criei um solo teatral (Madrugada), e sobre os quais fiz meu mestrado (BARBOZA, 2001). É importante lembrar que me interessavam, então, as máscaras como meio para a formação do ator; não me dediquei ao aprofundamento de estudo de resultados estéticos com as máscaras nem ao estudo da chamada clownaria clássica, os números da tradição circense. A prática com o universo do Palhaço é um exercício escancarado de amplificação da escuta, conforme a compreendemos aqui. Escuta evidenciada na relação física do palhaço com todas as duplas presentes na linguagem: seu próprio corpo (ou partes dele), um outro palhaço, o público (a relação do palhaço é sempre com um), os objetos, os sons ouvidos etc. A linguagem é um dos treinos exemplares da abertura para a escuta total no corpo de um ator, pois é nela que o palhaço se funda, por ela que ele existe e é. O trabalho com o Bufão tem no estudo da paródia um de seus principais fundamentos, e a base do início do conhecimento da máscara era a recuperação, em cena, de narrativas pessoais dos atores que deveriam ser parodiadas. A experiência com a paródia dedica-se ao esgarçamento das possibilidades físicas do ator, pela sagacidade que o Bufão tem com o discurso, na alta exigência de escuta da oralidade, para poder parodiar tudo o que ouve, e de escuta da leitura, para poder parodiar o que lê. Tudo isso afirmava em mim a necessidade de insistir na palavra, agora com uma lupa ácida, mas generosa.

Enquanto começava a conhecer o Bufão em meu corpo, escrevi a biografia de um médico, antigo exilado político, como trabalho final para a disciplina Jornalismo Literário Avançado e Histórias de $\mathrm{Vida}^{20}$, experiência que abriu caminhos para o

${ }^{20}$ Coordenada pelo Prof. Dr. Edvaldo Pereira Lima no CJE-ECA-USP, em 1999. O trabalho chamou-se "As cores do exílio", e é uma minibiografia do médico David José Lerer. 
aprofundamento de exercícios que envolviam a escrita e a ação de contar histórias de vida que dialogavam diretamente com minhas práticas teatrais daquele momento.

Localizo as duas experiências acima apontadas, o encontro com a máscara do Bufão e com algumas técnicas para trabalhar com narrativas de histórias de vida, pois acredito terem sido também decisivas para a gestação do tema da pesquisa aqui traduzida. Moviam-me questões acerca das relações entre o ator e a palavra dita por ele em cena.

Há um encontro, que não se cansa de abrir portas para lugares sem fim, com Antonio Januzelli (Janô), professor e formador de atores da Escola de Comunicações e Artes (CAC e EAD), onde lecionou durante aproximadamente 30 anos, diretor e ator, autor de $A$ aprendizagem do ator. Janô foi meu professor na graduação e na pósgraduação, virou parceiro de trabalho e juntos dirigimos Oito (na EAD, estágio de formatura em 2006) e realizamos com apoio da Fapesp a pesquisa Práticas do ator: anotações à margem (1999/2000), registros de oito práticas de trabalho do ator dos pesquisadores Beth Lopes, Cristiane Paoli-Quito, Francisco Medeiros, Hélio Cícero, Luiz Damasceno, Márcio Aurélio, Myrian Muniz, Ricardo Puccetti, a ser publicada em 2009. As entrevistas com esses atores e diretores deram-me ganas de perseguir no meu tema.

O encontro com a professora Maria Lúcia Pupo, acontecido também na graduação e na pós-graduação, seu curso Interseção entre Jogo e Texto: Aprendizagens e Perspectivas Contemporâneas, e diversas trocas daí decorridas nutriram imensamente minha pesquisa, permitindo, entre outros trabalhos (práticos e teóricos) a partir da palavra, a realização da monografia $A$ palavra com vida: o narrar como prática para 0 ator, organização primeira de muitas pistas e práticas que trago para esta tese.

Mas estão também aqui presentes encontros com práticas advindas de outras áreas, minhas experiências com atores em cena ou em espaço de aprendizagem ou 
preparação para peças, com alunos em espaços formais e informais, com outros professores, com diretores, com amigos e com livros de todo tipo.

$\mathrm{Na}$ transcriação ${ }^{21}$ necessária ao decidir fazer virar texto algo acontecido em sala de trabalho prático, o encontro fundamental é com minha orientadora Sílvia Fernandes: a cuidadora mais generosa e insistente para que eu escute minha própria voz. Em seu cuidar, não permitiu que eu recusasse dois outros livros que insistiam também nessa escrita, mas que me amedrontavam em suas aparições.

Em mais um arroubo de petulância adolescente, em outubro de 1985 comprei o livro De segunda a um ano, de John Cage, após assistir um concerto do músico (poeta? ${ }^{22}$ ) na $18^{a}$ Bienal Internacional de São Paulo. Sua escrita é “mosaico de idéias, proposições, palavras e estórias, diários, operações ao acaso", em suas próprias palavras. E nela, aquele senhor grisalho que tocava o silêncio ${ }^{23}$ me mostrava escancaradamente:

que a vida era muito longa;

$>$ que eu poderia aceitar, desde ali, as palavras que viviam em mim a partir de alguma descontinuidade;

que as palavras podem afirmar e perguntar ao mesmo tempo;

que interrupção não é quebra, mas renascimento;

que, ao mesmo tempo em que nada precisa ser separado de nada, diz: “Espaço. Mesmo perto, há distância.” (CAGE, 1985, p. 85)

Em dezembro de 1986 ganhei de um namorado o livro Sendas de Ôku, de Matsuo Bashô. Além do diário de viagem “do mais importante poeta japonês, pai do hai-kai"

\footnotetext{
21 Termo que tomo emprestado do tradutor e poeta Haroldo de Campos.

${ }^{22}$ A provocação é de Augusto de Campos no prefácio "Cage: Chance: Change", In: CAGE, 1985, p. IX.

${ }^{23}$ Assisti à execução de 4'33"' (quatro minutos e trinta e três segundos), composta em 1952 por John Cage, para um ou vários instrumentos, que deve ser executada sem que nenhum som seja tocado.
} 
(PAZ, 1986, p.27) que dá título ao livro, o exemplar traz, dentre outros, o artigo de Octavio Paz intitulado "A tradição do haiku”, de 1970. Nele, li:

Este é um diário de viagem que é também uma lição de desprendimento. 0 provérbio europeu é falso: viajar não é 'morrer um pouco' mas sim exercitar-se na arte de despedir-se para assim, já leve, aprender a receber. Desprendimentos seriam então a mesma coisa que aprendizagens. (PAZ, 1986, p. 7)

Escutar a palavra a partir da abertura de quem muda de lugar, leva pouca bagagem (a síntese na sensibilidade japonesa ${ }^{24}$ ) e recebe, em sua imensidão íntima, tanto a trajetória da viagem como o desconhecido das paradas. A perambulação que permite abrir espaços internos. A impermanência oferecida pelas minhas vinte e poucas casas.

O ator que tem o texto à sua frente e que levará à cena a anterioridade do lido.

Ler recebendo o que se lê. O contrário do ler impondo-se à palavra. Estou aqui, sou aqui ao ler a palavra e ao dizer a palavra, mas quase não estou aqui, quase não sou aqui. Você, palavra, me é aqui e aí, onde está, de onde provém. Eu, aqui, em minha disponibilidade frugal e pobre (PAZ, 1986, p. 44) ), sem esperar nada, recebo esse nomear-as-coisas que a palavra oferece. Ou é você, palavra, que me atravessa justamente porque não espero nada daí?

No começo desse diário, Bashô deixa a casa:

"Os meses e os dias são viajantes da eternidade. 0 ano que se vai e o que vem também são viajantes. Para aqueles que deixam flutuar suas

\footnotetext{
24 “Neste caso não devemos reduzir a palavra sentir ao sentimento ou à sensação; tampouco a segunda acepção do vocábulo (ditame, parecer) convém inteiramente ao que quero expressar. É algo que está entre o pensamento e a sensação, o sentimento e a idéia. Os japoneses usam a palavra kokoro: coração. Mas já em seu tempo José Juan Tablada advertia que era uma tradução enganadora: 'kokoro é mais, é o coração e a mente, a sensação e o pensamento e mesmo as entranhas, como se aos japoneses não lhes bastasse sentir só com o coração’. As vacilações que experimentamos ao tentar traduzir este termo, a forma em que os dois sentidos, o afetivo e o intelectual, se fundem nele sem se fundirem completamente, como se estivessem em perpétuo vaivém entre um e outro, constitui precisamente o sentido (os sentidos) de sentir." (PAZ, 1986, p. 9)
} 
vidas a bordo dos barcos, ou envelhecem conduzindo cavalos, todos os dias são viagem e sua casa mesma é viagem.

Entre os antigos, muitos morreram em plena rota. A mim mesmo, já há muito tempo, como giro de nuvem arrastada pelo vento, agitavam-se em mim pensamentos de perambulação.

Depois de ter percorrido a costa durante o outono passado, voltei à minha choça às margens do rio e varri suas teias de aranha. Ali me surpreendeu o término do ano. Então me veio a vontade de atravessar o trecho de Shirakawa e chegar a Oku quando a névoa cobre céu e campos. Tudo o que eu via me convidava à viagem; tão possuído estava pelos deuses que não podia dominar meus pensamentos; os espíritos do caminho me faziam sinais e não podia fixar minha mente nem podia me ocupar de nada.

Remendei minhas calças rotas, troquei as tiras de meu chapéu de palha e untei minhas pernas, para fortalecê-las. A idéia da lua na ilha de Matsushima preenchia todas as minhas horas. Cedi minha cabana e fui embora para a casa de Sampu, para esperar aí o dia da saída. Em um dos esteios de minha choça pendurei um poema de oito estrofes. A primeira dizia assim:

Outros agora

em minha choça - amanhã, casa de bonecas."25

${ }^{25}$ BASHÔ, 1986. p. 49. 
A palavra 'lugar' significa originalmente ponta de lança. Na ponta de lança, tudo converge. No modo mais digno e extremo, o lugar é o que reúne e recolhe para si. O recolhimento percorre tudo e em tudo prevalece. Reunindo e recolhendo, o lugar desenvolve e preserva o que envolve, não como uma cápsula isolada mas atravessando com seu brilho e sua luz tudo o que recolhe de maneira a somente assim entregá-lo à sua essência. (HEIDEGGER, 2003, p. 27)

A casa do poeta que parte vira lugar de festa, de celebração.

O poeta chora, em síntese, o prazer de viver. Detalhe que punge: haiku.

O indesenvolvível da notação do haiku e o não fazer sonhar da foto de Barthes: ambas imobilidades vivas. E o leitor/olho diante da impossível expansão retórica. Palavra e imagem nas quais tudo está dado, sem provocar a vontade.

O diário que insiste em se mostrar.

Vinte anos depois, é por aí que reconheço origens possíveis para o que pergunta em mim.

Todas as leituras e todos os encontros lembrados têm sido parceiros que, muitas vezes sem qualquer intenção, acenaram e acenam para a existência do lugar. 
Mas nós não cremos na utilidade das filiações. As alianças são mais importantes que as filiações.

Gilles Deleuze, sobre Carmelo Bene, Un Manifeste de Moins

\section{SOTIGUI KOUYATÉ: espanto e encanto na aliança com um griot.}

\section{Escuta de bicho (homem), experiência-impulso para a prática virar escrita}

Junho de 2002, Rio de Janeiro, RJ, Fundição Progresso.

Regras do jogo: estágio coordenado por Sotigui Kouyaté.

Sotigui Kouyaté mostra um vídeo de uma região do Burkina Faso na qual há uma espécie de crocodilos gigantescos aos quais os humanos confiam pedidos relativos ao plantio, à colheita, questões de caráter pessoal, pedem bênçãos e, ao fazê-lo, sentam em cima de seus dorsos. São chamados de crocodilos sagrados. Depois de passar o vídeo (L'homme et le crocodile), Sotigui propõe a prática: duas pessoas no centro de uma roda formada por mais de 40 pessoas. Uma olha as costas da outra, que está, portanto, de costas para a primeira. Elas estão a uma distância de aproximadamente um braço. As duas devem se dedicar a receber uma à outra, focar realmente em estarem juntas, encontrando-se a partir de alguma calma, ali. A pessoa que olha as costas da parceira deve dizer uma frase acompanhada de um gesto, algo simples, cotidiano, sem teatralidade. A pessoa da frente, que não a vê, deve, sem um lapso de tempo grande, repetir o que recebeu, gesto e palavra, a partir do estado de recepção lembrado no início pelo orientador. Em seguida a dupla repete a prática, invertendo a pessoa que inicia fala e gesto. Depois de cada sequência, uma mostra à outra o que fez, momento em que ambas checam a parecença, diferença ou igualdade entre as ações integrais. Fiz parte da primeira dupla a realizar essa experiência neste estágio, o primeiro de seis de que participei com Sotigui. 0 rapaz - um jovem capoeirista que acabara de conhecer repetiu minha fala e meu gesto com exatidão espantosa e vice-versa. Ao terminar a 
experiência, retornei à roda e sentei-me num choro (de tipo convulsivo) que misturava pensamentos-corpo escorridos nas lágrimas deles também nascidas: atentava-me para a esquecida possibilidade humana desse alto nível de sutileza na sensibilidade, a consciência, apercebida em sua máxima corporeidade, do imenso silêncio onde nasce a palavra, o invisível e o visível simultaneamente comunicados com precisão numa ação tão, tão simples. Misturada a isso tudo, a percepção da didática daquele homem ${ }^{26} .0$ exercício não começara na transmissão das regras. 0 exercício começara com o vídeo. Ele não relacionou nada por meio de palavras, jamais. Apenas nos ofereceu as experiências.

Minha confidência íntima relativa à experiência descrita é a de que eu tive a nítida impressão de ter sido apresentada a um lugar que parecia ser uma recordação. Esse lugar, em mim, era, ao mesmo tempo, novo e antigo, muito antigo.

$\mathrm{Na}$ experiência, tanto a não-separação entre as coisas quanto a imensa-e-calma abertura de espaços na escuta da palavra nascida com o gesto, e dele inseparável, me convidaram, naquele justo momento, a escrever sobre as práticas às quais vinha me dedicando. O que não sabia era que esse encontro duraria tanto, nem que ele ainda viria a me oferecer tantas aberturas.

Em junho de 2002 participei do primeiro estágio no Brasil coordenado por Sotigui Kouyaté, griot e ator africano, integrante, desde 1982, do Centro Internacional de

\footnotetext{
26 “A origem de 'didática' remonta ao verbo grego didásko, que significa 'ensinar'. (...) Também o verbo didáskein refere-se ao âmbito do ensino, e foi tradicionalmente explicado como produto de uma raiz com sentido geral de 'receber' - testemunhada na forma homérica dékto, 'o que recebia' - e, em sua forma passiva, 'ser recebido', 'adotado'. (...) De acordo com uma segunda hipótese didásko proviria do tema dns, testemunhado também no grego dénea e em temas do sânscrito como dámsas e dasrá, com o significado de 'que faz milagres'. O sentido básico dessa raiz seria, então, p de 'poder milagroso', 'façanha'. (...) Além dessa primeira evolução, se desdobram as formas configuradas sobre um presente causativo e iterativo que agrega o sufixo -sk- à raiz e tem por resultado didásko, 'ensinar', no qual é preciso levar em conta seu sentido causativo: 'fazer saber', 'fazer com que alguém aprenda'. Em tal sentido, provavelmente em grego o termo nunca teve o valor sobrenatural testemunhado em sânscrito, mas possivelmente se tenha voltado à idéia de habilidade." (CASTELLO e MÁRSICO, 2007. pp. 89-90)
} 
Pesquisa Teatral, dirigido por Peter Brook. ${ }^{27}$ Sotigui ministraria, então, mais cinco estágios no país. Um primeiro em 2003 (no Rio de Janeiro), sobre as relações entre o ator e a palavra no trabalho específico com os contos, e três estágios dedicados ao trabalho com a escuta, em 2003, 2004 e 2006 (em São Paulo). A convite de Sotigui, entre dezembro de 2003 e janeiro de 2004 fui à África Ocidental, onde, durante 30 dias, visitamos pessoas no Mali (em Bamako) e no Burkina Faso (em Bobo-Dioulasso, Ouahabou e Ouagadogou). Novamente, entre dezembro de 2007 e janeiro de 2008, viajei ao Burkina Faso (Ouagadougou, Pa, Nasso, Bobo-Dioulasso, Ouahabou), a seu convite e de seu filho, Hassane Kouyaté, para participação no Festival Yeleen, de contadores de histórias - onde fiz o estágio coordenado por Toumani Kouyaté -, e para participar do primeiro estágio coordenado por Sotigui para 22 atores africanos de vários países (Burkina Faso, Costa do Marfim, Guiné, Mali, Senegal, Togo), trabalho preparatório da montagem da peça Salina, de Laurent Gaudé.

O encontro com Sotigui Kouyaté marca definitivamente a trajetória da minha vida - dentro e fora dos espaços de trabalho onde nos encontramos -, pois confirma meu interesse pelas relações entre o ator, a palavra e a cena, insiste no meu desejo de aprofundamento das práticas com o 'narrar' (que já me ocupavam desde o trabalho com o Bufão, mas foram transformadas), e, acima de tudo, nomeia, pela primeira vez, com extrema clareza, a percepção quieta e a sensibilidade sutil como escuta. Sotigui busca sensibilizar o homem (muitas vezes, o ator, mas nem sempre...) para fazer a mediação entre os mundos interior e exterior da maneira mais tranquila possível.

Sotigui Kouyaté nasceu em Bamako, no Mali, é de origem guiné e foi criado no Burkina Faso. Essa região pertence ao antigo Império Mandinga, onde a tradição dos griots ainda é viva. O griot, segundo o próprio Sotigui, é o “senhor da palavra”, sendo também a memória do continente africano. Eram os griots que transmitiam a genealogia

\footnotetext{
${ }^{27}$ Kouyaté fez, entre outros, os filmes $O$ Mahabharata, O céu que nos protege, Golem, Coisas belas e sujas, Little Senegal, Génésis e Little River (com o qual ganhou o prêmio de Melhor Ator no Festival de Berlim em 2009), e esteve no Brasil com as peças Le Costume (2000), Hamlet (2002) e Tierno Bokar (2004).
} 
do continente ao povo. Ainda hoje eles são os conselheiros dos reis e políticos, são os mediadores junto ao povo, entre as famílias, entre os casais, responsabilizando-se por atuar diretamente no equilíbrio da sociedade. 0 griot é também artista. A arte da palavra, nessa tradição, é um dom que passa de pai para filho. 0 griot também dança, canta, toca. ${ }^{28}$

Os griots e as griottes são gente da palavra e da música; capazes de verdadeiras acrobacias lingüísticas, eles são cantores, contadores, genealogistas, historiadores, trovadores e ao mesmo tempo loucos ou bufões. Eles são acompanhados por numerosos instrumentos musicais (...). Eles são, além disso, mediadores e mensageiros, indispensáveis dentro de uma sociedade na qual são os únicos a poder se expressar livremente. Vivem de louvores que endereçam aos poderosos, das narrações históricas que declamam nas festas, dos contos morais que contam ou cantam por ocasião das cerimônias das quais participam, dos serviços que oferecem quando intervêm nos conflitos. (STAMM, 1999, pp. $63,64)^{29}$

Após a primeira viagem ao Mali e ao Burkina Faso, as práticas que eu havia iniciado começaram a se aprofundar e tomaram novos rumos.

Fizemos uma viagem que ele nomeou a mim viagem de apresentação, experiência na qual pude partilhar a intimidade da vida dentro das casas e receber um pouco do nobre modo de vida das pessoas que conheci. É tarefa difícil sair de certa atitude generalista ao relatar, de maneira sintética, as experiências nesses dois países que interessam especificamente a este trabalho, pois tudo o que vivi ecoa aqui. Os temas que chamaram minha atenção foram, sem dúvida alguma, a assombrosa capacidade de escuta e memória das pessoas com as quais convivi, uma alegria muito presente nas relações humanas, nas ruas, nos ônibus, nas casas, nas festas - surpreendente diante da extrema miséria econômica dos países em que estive ${ }^{30}$-, e o enorme comprometimento que eles parecem ter com as relações em coletividade.

\footnotetext{
${ }^{28}$ Para um aprofundamento em questões mais específicas indico: BERNAT, 2008.

29 Livre tradução minha.

${ }^{30}$ Segundo publicação do último IDH (2005), o Mali é o quarto país mais pobre do mundo e o Burkina Faso o terceiro.
} 
Entre todos os povos do mundo, constatou-se que os que não escreviam possuíam uma memória mais desenvolvida. Demos o exemplo dos genealogistas que conseguem reter uma inacreditável quantidade de elementos, mas poderíamos mencionar também o caso de certos comerciantes iletrados (ainda conheço muitos deles) que dirigem negócios envolvendo por vezes dezenas de milhões de francos, e emprestam dinheiro a muitas pessoas no curso de suas viagens, guardando de memória a mais precisa contabilidade de todos esses movimentos de mercadorias e dinheiro, sem uma única nota escrita e sem cometer o menor engano. 0 dado a ser retido fica imediatamente inscrito na memória do tradicionalista, como em cera virgem, e lá permanece sempre disponível, em sua totalidade Esse fenômeno poderia estar relacionado com o fato de as faculdades sensoriais do homem serem mais desenvolvidas onde há necessidade de se fazer grande uso delas e se atrofiarem em meio à vida moderna. 0 caçador africano tradicional, por exemplo, pode ouvir e identificar determinados sons a vários quilômetros de distância. Sua visão é particularmente acurada. Alguns têm a capacidade de 'sentir' a água, como verdadeiros adivinhos. Os tuaregue do deserto possuem um senso de direção que está próximo do miraculoso. E como esses há dezenas de exemplos. O homem moderno, imerso na multiplicidade de ruídos e informações, vê suas faculdades se atrofiarem progressivamente. Está cientificamente provado que os habitantes das grandes cidades perdem cada vez mais sua capacidade auditiva.

Uma das peculiaridades da memória africana é reconstituir o acontecimento ou a narrativa registrada em sua totalidade, tal como um filme que se desenrola do princípio ao fim, e fazê-lo no presente. Não se trata de recordar, mas de trazer ao presente um evento passado do qual todos participam, o narrador e sua audiência. (BÂA, 1991, p. 214)

Mas conviver com o fato de a intimidade ser partilhada e tornada pública, cotidianamente, foi um dos maiores arrebatamentos desses encontros.

A aproximação com a tradição griot, nessas viagens, de maneira mais direta, é que adquire maior importância aqui. Convivíamos cotidianamente com essas figuras que entram e saem das casas, prestam homenagens pelas ruas, em cerimônias de casamentos, batismos e funerais, em performances e shows musicais, durante as refeições, aconselham-se mutuamente, alternam-se nos papéis de griots (ou griottes, as mulheres) e respondedores um do outro. Sua performance (que é seu estar no mundo) é parte do cotidiano, no qual nada é separado de nada.

Fundada na iniciação e na experiência, a tradição oral conduz o homem à sua totalidade e, em virtude disso, pode-se dizer que contribuiu para criar um tipo de homem particular, para esculpir a alma africana. Uma vez que se liga ao comportamento cotidiano do homem e da comunidade, a 'cultura' africana não é, portanto, algo abstrato que possa ser isolado 
da vida. Ela envolve uma visão particular do mundo, ou, melhor dizendo, uma presença particular no mundo - um mundo concebido como um Todo onde todas as coisas se religam e interagem. ${ }^{31}$

O griot atua sempre em parceria com uma espécie de respondedor (um outro griot) a seu lado, seu acompanhador, sujeito que tem, entre outras, a função de devolver a escuta ao griot que fala, mantendo o ritmo e a vivacidade de sua fala e, ao mesmo tempo, sendo responsável por assegurar a comunicação do griot com o público que o escuta. Esse respondedor (palavra usada em francês para traduzir námúnamulá, em maninca), diz “naamu”, que quer dizer "eu te escuto", e o ritmo com que diz esse "naamu" mantém o pulso da fala daquele griot. 0 respondedor checa também com o público a clareza do que está sendo dito. É ele quem pede para o griot repetir algo já dito, caso ache que o público não está envolvido ou não escutou com clareza a ideias do griot. A impressão que tenho é de que o respondedor liberta a escuta do griot que profere algo, reforçando-a, pois divide-a com o primeiro, e é uma espécie de cuidador das relações entre 'cena' e 'público'. 32

Mas não podemos esquecer que meu olhar para essa tradição é influenciado pela ótica de um homem específico, que trabalhou durante 23 anos no Centro Internacional de Pesquisa e Criação Teatral, dirigido pelo inglês Peter Brook, em Paris, na França. Um griot, diretor e ator que foi para o Ocidente trabalhar num centro que tem como princípio de investigação a complementaridade presente nas relações entre diferentes culturas. Segundo Brook, esse centro foi fundado para explorar "o que anima uma cultura, os elementos que podem ser reconhecidos como humanos"33.

\footnotetext{
31 “É nas sociedades orais que não apenas a função da memória é mais desenvolvida, mas também a ligação entre o homem e a palavra é mais forte. Lá onde não existe a escrita, o homem está ligado à palavra que profere. Está comprometido por ela. Ele é a palavra, e a palavra encerra um testemunho daquilo que ele é." (BÂA, s/d, p. 183) ${ }^{32}$ Muitas dessas informações foram esclarecidas em conversas com Hassane e Sotigui Kouyaté, entre 2003 e 2008.

33 "O ator de Brook vai ao encontro do espectador, tateia o ar, os temperamentos, as reações, sem propor um modelo preciso ou um código fixo. Ele pode improvisar em frente aos africanos, aos mexicanos, aos surdos-mudos. Ele habita seu próprio corpo, põe em jogo sua energia, é capaz de saltar no vazio, quer dizer, intervir na cena sem a segurança de um texto. Sabe entrar num estado e sair dele, sua narrativa é inteiramente aberta na direção do espectador. Ele controla seu olhar e sua escuta. Ele reage 'em grupo'. Com esse ator disponível, desperto, Brook se esforça para aumentar a intensidade das percepções do espectador.” ASLAN, 2003, pp. 297, 298. (A tradução é nossa.)
} 
Nunca estivera em uma região de tradição exclusivamente oral. As práticas que venho delineando são diretamente influenciadas pela aliança entre o espanto e o encanto dos encontros com Sotigui ou, de algum modo, por ele mediados, nos seis estágios com ele, um estágio com seu filho, outro com seu sobrinho e nas duas viagens aos seus países de origem. Mas fui flechada e pungida também pela oportunidade de vêlo em cena muitas vezes - sendo que em uma mesma peça vi-o mais de sete vezes -, de ver seu parceiro, o ator malinês Habib Dembélé, também sete vezes em uma mesma peça, seu filho Hassane Kouyaté, e diversos outros griots e griottes nesses espaços híbridos, que misturam cotidiano e teatralidade, nas cidades visitadas.

A força-calma de seus corpos (não de todos, bem dito, mas de muitos e muitos deles), a intensidade e leveza com que transitam do corpo cotidiano para o corpo teatral, a capacidade de se deslocarem entre o narrar e o fazer dentro do jogo - indo e vindo com muita liberdade -, sem perder nunca a conexão extremamente viva com a platéia e com tudo que rodeia a cena (ou a vida ao redor) sempre me impressionou. Recebo, ali, de seus corpos, o vínculo mais suave e intenso que jamais experimentei na complexidade entre o público e o privado, entre o íntimo e o declarado, entre intimidade e distância, entre presença e sentido, entre o visível e o invisível, entre o sagrado e o cotidiano, entre o segredo e o exposto, e, enfim, entre o silêncio e a palavra. Sempre com espaço para o outro, qualquer outro.

Eu agradeço. 


\title{
ENTRE O ATOR E A PALAVRA: escuta e demora de algum silêncio
}

Leiamos, sem pressa, o texto:

\begin{abstract}
A vida de um homem é o instante onde o mundo, em vão, se ilumina. A pedra, a lua e o rosto do outro não seriam comemorados se o breve trânsito de nossa aparição não contasse com a língua e com a palavra. Também os gestos ou a dança, igualmente celebram, mas é na palavra das coisas que o mundo deixa de ser mudo e pode tocar a aparição. Se o homem deixar de existir e apenas o lagarto ou outro animal grunhir para a lua, então ela será menos lua e algum deus criador que acaso persista em sua incansável persistência terá de reconhecer que sua "obra" não é mais devidamente celebrada e ele, junto de seu imenso narcisismo trabalhista, teria de se suicidar. Celebrar é estar exposto e atingido pelas coisas a ponto de, ao dizê-las, guardar-lhes a vibração, comemorá-las. Estar atingido também pela proximidade do rosto do outro é enxergá-lo a partir do aberto, não sendo o aberto mais do que o lugar de uma aparição intrinsecamente frágil, de uma aparição-desaparição. Mas o homem não gosta de estar exposto; ele é alérgico ao lugar. E, enquanto alérgico, converteu-se num animal blindado e, quando alguém aponta o céu (como um personagem de Bernhard) e diz: "veja, ali está aberto, vejam, está aberto; a palavra a-ber-to está redigida no firmamento", então, já não se percebe o que isso quer dizer, pois o homem blindado gosta de viver no fechado e medir a palmo. 0 homem blindado expulsou a hospedagem: não está aberto à visitação dos afetos ou da palavra. (PESSANHA, 2002. pp.13-14)
\end{abstract}

Ocupados com o falar que nos blinda, visitados pelo dizer ininterrupto que nos ocupa (falamos continuamente), podemos, atores, abrirmo-nos à visitação da palavra? Podemos encontrar alguma quietude que permita essa visitação? Para, quem sabe, sermos veículos de um dizer menos ansioso, menos precipitado, menos impositivo, e, por sua vez, então, mais orientado pelo 'quieto', pela real escuta da palavra que nos visita, e na qual queremos morar? E, no fim das contas, podermos encontrar o público numa real partilha de experiências, num nomear que se torne aproximador? Pode haver celebração como essa?

Se o aberto é lugar frágil de uma aparição-desaparição, pensaremos como nós, atores, podemos ser escutantes dessa fragilidade, para que sustentemo-nos neste justo lugar. Além de termos a chance de demorarmo-nos por aí... 
O que faz o ator diante de um texto, ao lê-lo com sua voz? Penso em minhas experiências como atriz, seja em peças feitas seja em cursos, a partir das coisas que me foram ensinadas, transmitidas, e, ao mesmo tempo, nas experiências das quais pude ser testemunha com outros atores, também em peças ou cursos. 0 ator imprime sua fala cotidiana para que o texto seja dito com alguma 'verdade' ou com alguma ‘naturalidade’. Começa a ler em voz alta para trazer para si aquilo que ali está, a partir de seu corpo em estado mais conhecido, cotidiano. Outra possibilidade é o ator imprimir sua maneira de dizer de modo 'teatral', já com volume e entonação que ele considera adequados àquela categoria textual ou que ele aprende enquanto lê e imediatamente dá forma para uma melhor 'comunicação' e 'clareza'. Essa 'fala teatral' também nos é frequente experimentar, seja porque já a possuímos, seja porque ela nos é exigida por quem coordena o trabalho de fora da cena. Mas há ainda as possibilidades de expressão das nossas vocalidades. Experimentamos, muitas vezes, diferentes formas de ler, seja aplicando o conhecimento de nossas diversas vocalidades (qualidades distintas ou maneiras de dizer), seja simplesmente brincado com as palavras como jogo. No primeiro caso, podemos ler ou dizer um texto aplicando às palavras a qualidade de torcer, a qualidade de perfurar, ou podemos privilegiar algumas ressonâncias sonoras, como, por exemplo, dizer um texto na região do peito, ou na da cabeça, ou nas costas. No segundo caso, ao tratar as palavras como jogo, posso dizer uma frase sussurrando-a, outra como se eu mesma (minha voz) fosse uma mosca, outra como se eu atirasse as palavras de uma metralhadora, outra como se o texto subisse uma escada. Certa vez, numa experiência de leituras do texto Macbeth, de William Shakespeare, com o grupo Amok Teatro, do Rio de Janeiro (RJ), para seleção de atores para uma montagem, ouvi também a expressão 'ator carregado': o ator deveria estar carregado fisicamente antes de dizer um texto. Ele deveria provocar um resultado de um esforço interno que exigisse tensão e desse-lhe 'energia': a leitura do texto deveria começar daí, desse 
'carregamento' do ator. Os atores que demonstravam a técnica tremiam e me davam a impressão de fazer muito esforço físico.

Algumas dessas palavras me espantam. Por isso, retrocedo na relação do ator já com o texto para lembrarmo-nos do escrito, da palavra no papel, e daquele que a lê, que se torna, ao dizê-la, o próprio corpo do que percebemos, ouvimos, vemos e escutamos. Perceberemos, ainda, que, nessa relação, todo o tempo, o ator deve oscilar (e duvidar na própria oscilação) entre lembrar-se de si e esquecer-se de si.

“A voz é nômade, enquanto a escrita é fixa.” (ZUMTHOR, 2005, p. 53)

O trabalho do ator com a voz ao vivo implica na compreensão do que se diz aí: ele manuseia sempre essa fixidez da escrita e, ao mesmo tempo, a corporeidade total do dito, com peso, calor, volume do corpo todo, do qual a voz é apenas uma amplificação, além de tudo o que há no homem de carne e sangue que encontra o literário. Antes de tudo, o que há é esse corpo que lê e percebe o escrito. Por isso retrocedemos até aqui. O ator pode, antes de desejar expressar algo com o lido, lembrar-se de si, conectar-se a si. As práticas que guiam o ator ao encontro de um lugar quieto ${ }^{34}$ em seu corpo podem abri-lo para uma relação aberta e escutante com a palavra.

$\mathrm{O}$ ator performa ao dizer o texto, primeiro porque é presença, existe no tempo e no espaço, "ouve, respira, abre-se aos perfumes, ao tato das coisas", e também porque em sua prática há um espectador-ouvinte a quem ele se destina, enquanto ambos estão dentro de um espaço (mais ou menos) ficcional que marca também o texto dito ${ }^{35}$.

Insistamos na presença, demorando-nos, talvez, sobre algumas obviedades. Presença fala de vínculo consigo mesmo e com todo o entorno, fala de estar vivo, envolver-se totalmente, comprometer-se integralmente (corpo-e-pensamento inseparáveis). Presença é co-centramento, envolvimento, interesse, 'estar onde se

\footnotetext{
${ }^{34}$ Apontamos nossas experiências a partir desse lugar a partir da página 65.

${ }^{35} \mathrm{Na}$ passagem referida, o autor espreme a noção de performance para extrair dela sua substância. (ZUMTHOR, 2000, p. 45.)
} 
está ${ }^{36}$. Ao mesmo tempo, presença é ausência de esforço. Normalmente quando 'quero' estar presente, estou presente somente em algum querer para o futuro, o que significa, portanto, viver no vislumbre desse futuro, não estar presente na presença, correndo o risco até de re-presentar a presença, torná-la característica, qualidade para um 'papel': o papel do ator presente.

A especificidade da ex-posição no trabalho do ator já nos remete ao assunto da presença. Ele dá a ver, para quem está fora (ex), sua posição. Posicionar-se é estar em si, ver-se, ouvir-se em si, presente no presente. Dar a ver essa posição, independentemente de suas opções estéticas, é fundamento do trabalho do ator. $\mathrm{Na}$ mesma medida, porém na outra ponta dessa escala, esconder sua posição também é presença, pois é uma outra ex-posição que se dá. Ele expõe o esconder-se.

Estar presente pode falar, então, sobre estar próximo de si. Mas próximo de si já compreende alguma distância, há duas palavras (próximo e de) antes do 'si' para dizer estou. Por isso, talvez, presença total no ofício do ator, ou o que ele nos ensina para existirmos, seja justamente a percepção-em-pensamento-no-corpo desse espaço entre ser aqui e perceber-se aqui, num agora que já passou. Presença seria, então, vivida no presente mas percebida num futuro perto, próximo, que retorna a um passado recente, próximo? Três tempos se encontram e temos a impressão de que tudo se deu no mesmo instante: nesse átimo, temos a impressão de que realmente estivemos presentes?

Em caminho quase contrário ao que vínhamos desenvolvendo até aqui, se ficarmos na etimologia da palavra temos: o prefixo pre - do latim prae -, que dá tanto a ideia de anterioridade como a ideia de lugar, localização, e o radical sença, do latim sentia (o que está sendo), implica o verbo esse, ser, estar. Praesens, praesentis (adjetivo), presente, de praeesse, verbo que podemos traduzir por pre-ser ou pre-estar. Outros sentidos latinos ainda encontrados em praeesse são proteger, guardar, defender, ser

\footnotetext{
${ }^{36}$ Conforme Antonio Januzelli, Janô, em aulas frequentadas em 1990 e 2006.
} 
instigador de, incitar e ferir ${ }^{37}$. Estar presente seria, então, nesta experimentação com as etimologias, antever-se sendo a partir de um guardar, de alguma reserva, e, de certo modo, antecipar a percepção do estar ali em reserva, enquanto instiga, fere. Todo ator com uma escuta mais calma já deve ter vivido isso. É essa possibilidade de estar presente que nos permite mudar o rumo de uma ação, de uma situação, de uma experiência, como guias de nós mesmos e de tudo o que rodeia a cena. Numa experiência coletiva, se todos pudermos escutar com a máxima profundidade a partir dessa quietude e vigor, a presença pode solicitar, desde ela mesma, a chegada do público. Em minhas vivências com grupos tenho insistido aqui. $\mathrm{Na}$ teatralidade experimentada neste exato lugar. Lugar que tem me parecido muito mais teatral do que qualquer construção, excesso, máscara. E convido-nos a perguntar se são as exacerbações, que nos bombardeiam no cotidiano, que pedem ao teatro a limpeza, o des-encobrimento, a retirada de tudo o que vela a existência - com a consciência do ator absolutamente necessária a essa passagem (a consciência de sua teatralidade nesse lugar) -, oferecendo, justamente aí, a máxima teatralidade para nossa sensibilidade afogada pelos excessos. E encontro eco muito preciso a seguir.

Denis Guénoun, em $O$ teatro é necessário?, vai além do espaço de ensaio ou aula no assunto da presença, ao trazê-la como parte dos resultados ditos 'espetaculares' da cena contemporânea, nomeando-a existência cênica, existência física:

0 primeiro requisito do jogo provém da apresentação do corpo. Não da representação pelo corpo de alguma coisa da qual o corpo seria a figuração, mas da exibição do próprio corpo. Ora, essa mostração pretende alcançar uma verdade que não é a da adequação a uma imagem, mas a da integridade de uma presença. Este estar-aí sobre o palco não tem nada de ordinário: aqui a espontaneidade se revela falsa. Submetida ao olhar, ao fato da exposição, a espontaneidade, em cena, se mostra falsa. Trata-se então de elaborar uma verdade física. Os métodos variam: a procura da autocolocação de uma interioridade (que, diante do olhar, deve ser conquistada), ou, ao contrário, trabalho da exposição pela exposição, buscando sua eclosão como ostentação no âmbito da verdade. O horizonte é sempre o de uma precisão: do deslocamento, do gesto, do olho, da própria imobilidade. (...) Esse deslocamento da normatividade

\footnotetext{
${ }^{37}$ SARAIVA, 1993. p. 939.
} 
cênica em direção à seca apresentação, à precisão de um existir remetido a si mesmo e, contudo, oferecido ao olhar (ou ao ouvido), afeta todas as exigências da cena: a profundidade ou leveza da voz (mas que rejeita a voz encorpada, sempre plena, causa da dicção 'redonda' dos cantores); a disponibilidade aos parceiros de cena; a aceitação dos imprevistos e, sobretudo, a graça da não-afetação, o ser jubiloso, digno, aberto, livremente tenso. Mas o fato concerne, talvez ainda mais, à exibição das palavras. Porque o representado não é mais a verdade do texto. A verdade do texto teatral é desde então, intempestivamente, poética. E isto já há muito tempo: mas, hoje em dia, também ela se oferece nua. (GUÉNOUN, 2004. pp. 133-134)

O ator, para poder dar-a-ouvir essa verdade poética do dizer em cena, deve estar mais conectado aos espaços de abertura que nos propomos tocar. Se reconhecemos no por, na parceria com o público, colocar a "anterioridade do texto, distinto do ato de representação" enquanto faz a passagem do texto à cena, está na hora de adentrarmos em alguns vestígios de experiências: aqueles que nos têm revelado um como conduzir do texto ao visível paro ator dar a escutar alguma poesia, qualquer que seja sua matriz textual.

“O poeta não me confere o passado de sua imagem, e no entanto ela se enraíza imediatamente em mim." (BACHELARD, 1993, p. 2)

0 aceno do poético vive: em ambiente de prática tenho frequentemente a impressão de ver o lugar do poema na proximidade com os atores. Por isso, talvez, o espaço de ensaio, formação, preparação, venha pedindo o tornar públicas as experiências (uma voz interior ora sussurra, ora grita: "as pessoas tinham que ver isso; aqui é teatro"). Mesmo sem saber se quem está ali é (já) ou não ator (ainda). A teatralidade está presente em sua clara plenitude. 0 homem em estado de teatralidade seria um poeta-da-cena? Um poeta-cênico?

Para Heidegger, “poesia é na maior parte do tempo escuta." (HEIDEGGER, 2003, p. 126) 


\section{vestígios de práticas pelo campo}

Os das práticas trazidos para esta transmutação, ao serem fixados em escrita, não se querem método, sequência, ordenação. Eles sabem, também, que pertencem a uma outra língua que não esta e que nela há a voz, o corpo, a carne, o sangue. Esses vestígios podem (e pedem), caso os temas aqui tocados reverberem nos olhos que miram estas páginas, para serem substituídos pelas práticas que tenham, aos mesmos olhos, sido oferecidas em sua própria língua. Afinal, elas não têm fim, nem as línguas, nem as experiências.

A maior parte das práticas apontadas a seguir nasce de aquecimentos individuais e coletivos, em diálogo com tudo o que se disse aqui sobre pre-sença, quietude, silêncio, sem nos esquecermos, nunca, dos vulcões. Aquecer é 'tornar quente o que está frio,38 músculos, articulações, estado interno. As práticas de aquecimento - que não são foco desta escrita - podem ser de pequena ou grande intensidade física, mas, na maioria das vezes, compreendem: perceber seu estado geral, conduzir o corpo para relaxar, aquietar corpo e mente, preparar a pessoa para o trabalho que será feito a seguir, em vínculo estreito com ele.

Nos ambientes das práticas, sempre que o tempo permite, fazemos também desaquecimentos: passagens suaves para o retorno ao corpo retirado de seu estado de exposição. Vemos que, com isso, podemos guardar a experiência (que pede tempo para ser recolhida) em lugares mais fundos do que quando bruscamente a empurramos seja para um caderno de notas, seja para um pedaço do corpo qualquer, pela pressa que temos (ou que nos é exigida) em traduzi-la ou em abandonar o espaço de trabalho. Desaquecer é somente mais um dos gestos de cuidar. Desaquecer também pode trazer mais calma ao corpo que se afetou pelo vivido, quando realmente conduzimos

\footnotetext{
${ }^{38}$ Conforme Antonio Januzelli, Janô, em aulas frequentadas em 1990 e 2006.
} 
compensações necessárias para posturas vividas exaustivamente em cena, quando convidamos o corpo a retornar com suavidade por meio de uma observação cuidadosa do sair da cena e entrar na vida, atentos às variações de intensidades de cada espaço. A escuta da palavra começa também nesse reconhecimento do suave, nesse cuidado com o experienciado.

Lembremo-nos, uma vez mais, do que temos dito: toda palavra já é resposta: é um contra-dizer, um vir ao encontro, um dizer que escuta.

Lembremo-nos, uma vez, o que temos sonhado com o ator: escutar sempre enquanto dizemos e, ao dizermos, deixar o mostrar múltiplo, próprio da palavra, repousar em si mesmo.

Digamos, uma vez ao menos, a pergunta que ainda estava quieta e pede para soar: "Tornar imprevisível a palavra não será uma aprendizagem da liberdade?" (BACHELARD, 2005, p. 11) 


\section{vestígios de lugares-escutantes para receber a palavra na proximidade}

O ator diante do texto diz a si mesmo: esse texto deve ser meu, devo me apossar dele. Porém, a supressão apressada do distanciamento entre ele e a palavra não assegura o trazer para sua proximidade. Proximidade não é, necessariamente, pouca distância. Nosso assunto: o ator que re-colhe a palavra de um outro (ou se recolhe na palavra de um outro), a partir de alguma intimidade, proximidade. Sem perder o espaço, guardando todos os 'entre-as-coisas”, pois mesmo perto há distância.

Heidegger no texto "A coisa", para pensar proximidade pensa a coisa jarra. A jarra é "um receptáculo, algo que recebe outro dentro de si, um recipiente." ${ }^{39}$ Ela recebe, como recipiente, e, ao mesmo tempo, diz o texto, doa o recebido, ao verter o líquido que guardou.

0 ator, nesse lugar aberto a partir do qual ele recebe outro dentro de si o texto de um outro, em nosso caso. Parafraseando o autor alemão, o que tenho visto nesses lugares escutantes é a possibilidade de o ator receber, acolhendo o que dele irá vazar. As duas coisas ao mesmo tempo. É um lugar livre, no qual este vazio contido no livre pode receber a partir da ambiguidade do receber: acolhendo em seu vazio e retendo o que será doado, um pertencendo ao outro. 0 ator não se abandona, mas também não se impõe. É um recebedor que se recolhe e se concentra em doar.

Ao questionar a proximidade, Heidegger chega à jarra. Seu texto exige calma para ser ouvido (ele o fala, nasceu para uma conferência). Pede espaço para ser adentrado (ele mesmo oferece-o) e tempo para ser escutado (ele também o dá).

Além de lembrar ao ator a existência desse lugar, por meio da leitura de textos a maioria deles copiados ou indicados nesta tese -, para esse doar reunindo, experimentamos receber o texto a partir dos lugares apontados a seguir. As leituras

\footnotetext{
${ }^{39}$ HEIDEGGER, 2006, p. 149.
} 
desses textos alternam-se às práticas, entram no meio delas, contaminam tudo. São escritos em papéis grandes para que todos os leiam, são escritos em formas de bilhetes, cartas, em lousas, são lidos em voz alta por mim, por todos os presentes ou por um outro somente. Chegam ao espaço de muitas maneiras distintas, sendo que algumas vezes inteiros, outras em pequenos trechos.

\section{Um lugar para o quieto}

A pergunta que move este trabalho, nascida das impressões, ações e questões ${ }^{40}$, tem me conduzido a insistir na leitura do texto, repousar sobre ele durante um longo tempo, sem pressa de sair do papel, sair do lido. E normalmente lemos o texto a partir de práticas que nos oferecem um estado mais quieto, mais escutante, justamente por ser mais silencioso. O texto deve entrar aqui e não depois-daqui. São práticas que nos trazem para o estado de presença delineado anteriormente nas nossas teorias-moventes. Algumas das nossas são:

$>$ Chegar ao espaço de trabalho percebendo o seu percurso, desde onde partiu quando se destinava ao endereço presente. O laboratório da chegada, de Antonio Januzelli. Partir e chegar, e perdurar a chegada observando-se a si mesmo, despertando o nosso pássaro que observa. Lembrar do terceiro olho, daquele que nos vê (em nós, para dentro e para fora), sem perder a íntima conexão com o bicar. ${ }^{41}$ Daí para diante, não devemos mais nos esquecer dos pássaros.

Práticas simples, de nosso cotidiano, que exijam muita dedicação e concentração da atenção para serem realizadas. A dificuldade para determinado aluno ou ator

\footnotetext{
40 Transcritas às páginas 25 e 26.

${ }^{41}$ Ver página 11.
} 
pode ser costurar uma peça de roupa, ou simplesmente colocar uma linha numa agulha, ou realizar uma postura física que exija muita presença em sua execução. Aqui priorizamos ações impossíveis de serem realizadas mecanicamente, ações que sejam pouco conhecidas de nosso corpo, justamente para que, antes de ir à palavra, um corpo mais presente esteja aqui.

Práticas que trabalham o redondo no corpo e ações de continuidade, muitas delas advindas de meu aprendizado no Tai chi chuan, desde 1994. Em linhas gerais, todas elas têm como fundamentos a base (pés e pernas) muito plantada no solo, os joelhos bastante ou semiflexionados, a cintura livre, pois é condutora das ações, os braços como um prolongamento da cintura, nascendo dela, e ela, por sua vez, absolutamente conectada aos pés que abraçam o solo; o queixo sempre recolhido sobre o tronco, sem deixarmos a cabeça pender e pesar para frente, para o lado ou para trás. O eixo, a integração do corpo todo, são rigorosamente observados, mas busca-se, a seguir, o movimento redondo, e ações contínuas e repetidas inúmeras vezes. O repouso no gesto e no corpo, na duração e no perdurar de uma ação física, para ser continuado no repouso sobre o texto.

Cada ator tem uma folha em branco e uma caneta. Todas estão espalhadas pelo espaço. Por 5 ou 10 minutos a pessoa se escuta e escuta tudo ao seu redor, longe, perto, silenciosamente ou não, parada ou não. Ela pode cantar, andar, deitar, falar, emudecer... ela decide. Depois do tempo determinado, ela escreve na folha branca tudo que percebeu e que deseje traduzir ali. Reservamos 20 minutos para as práticas individuais de chegada, aquecimentos, relaxamentos, tudo o que a pessoa perceber que seu corpo pede para entrar em trabalho. Aqui tendo a orientar as escolhas das práticas de modo absolutamente pessoal, pois se alguém 
chega muito amolecido, relaxado, fleumático, não deve fazer a mesma prática que alguém que chega precipitado, atrasado, acelerado. Além disso, há as características individuais, os machucados, as doenças e as necessidades físicas, que não são comuns a todos. Depois das práticas pessoais, dedicamos-nos novamente a escutarmo-nos e escutarmos o espaço, o tempo, as coisas ao redor, em tempo idêntico ao que foi dado no início. E depois desse tempo, vamos ao papel em branco para traduzir o vivido. Seguem-se alguns relatos de atores nessa prática. $^{42}$

Relato de atriz, primeiro tempo

Entupimento. Buracos fechados. Muito barulho interior. A frequência dos automóveis é contínua. A boca tensa. Ao esticar a coluna estalo no ouvido: as portas tentam se abrir. 0 vento à direita. 0 vento à esquerda. A pele gelada quase não sente. Cheiro de amontoado de coisas velhas. 0 barulho dentro como móveis antigos que, de noite, não param de estalar. O barulho interior é contínuo. Não abri os olhos.

A mesma atriz, segundo tempo

Os aviões cortam o céu. 0 fluxo da Marginal é contínuo. Silêncio perto e clareza do longe. Passos atrás de mim. O interior se aquietou. Às vezes posso ouvir o ar entrando e saindo de mim. Pássaros como eco da casa de minha avó. Claridade e risco sonoro no céu. 0 som do antes-silêncio.

\section{Relato de ator, primeiro tempo}

A obrigação de escrever após o exercício me colocou a obrigação de prestar atenção e lembrar, para depois anotar. Algo mental. Me forcei a usar o sensorial. A dificuldade de silenciar e escutar com o corpo todo foi grande. Outra obrigação que me impus. Muitos pensamentos para depois entrar em consonância. A cabeça não pára. Sons, frio nos pés, olhos dormentes, um avião passa, tosses. A respiração está ofegante e o peito em movimento interno. 0 chão frio, som constante da Marginal, barulho do mundo girando, RRRRRRRRRRR, o Vicente passa a mão na rotunda. Como será que está a Magali? Curiosidade que passa. Abro levemente os olhos, vejo a Magali e fecho. Escutar com os olhos? Outro avião e três espirros em sequência. Algum movimento ao meu lado. Outra curiosidade. Abro os olhos e "Juliana com as costas nas costas de Otávio". Escutar com as costas. Fecho os olhos. Predispor a... Acordar com a escuta.

Mesmo ator, segundo tempo

Olhos fechados, ouvidos abertos. Escuto um pouco mais distante, tanto para o externo como para o interno daquilo que eu imagino que seja o centro. Agora, essas novas partes fazem parte desse raio que se ampliou. Agora é o mais distante é que altera a minha respiração, e um fundinho de medo aparece. Os carros da Marginal, os pássaros, e a respiração, o

\footnotetext{
42 Todos os relatos referem-se às práticas de um núcleo de trabalho formado pelos atores Daniela Duarte, Flávia Mellman, Magali Biff, Maria Ceccato, Otávio Dantas, Paulo Barcellos e Vicente Concillio, desenvolvidas entre outubro de 2006 e julho de 2007.
} 
calor das mãos. Abro os olhos. Agora a cobrança anterior não se coloca tanto. Aceito com mais tranquilidade os meus impulsos. Estou mais tranquilo para ouvir as minhas expectativas. Ver com os ouvidos. Ouvir o movimento.

Meu relato, primeiro tempo

Coração precipitado. Escuta precipitada. Um pouco de peso. Dúvida. Não sei se abro ou fecho os olhos. Necessidade de ouvir de olhos fechados e pelas costas. Vontade de perceber o que está por trás. Ansiedade de vêlos e vontade de aquietar o desejo de dizer "ainda não é para aquecer", "é só receber". Acalmo, ou busco acalmar. Nada em exagero. Ouço o surdo do tráfego, buzina, sonzinhos, tudo ainda misturado aos meus ruidinhos.

Meu relato, segundo tempo

Menos precipitada. Maior, infinitamente maior a percepção de meu corpo todo; ele mais integrado, esqueci o desejo de ver os outros, mas veio muito pensamento de "será que vão escrever como ficaram, será que vão descrever as ações, os movimentos?". Mais em cima dos pés. Vendo mais detalhe. A temperatura geral do corpo chama a atenção. Frente e trás mais ligados, pele em contato com roupa e sapato. Língua presente. Eu mais aqui e comigo.

- PRETO/BRANCO, prática sem nome aprendida com Sotigui Kouyaté, no estágio de 2002, no Rio de Janeiro (RJ). As práticas, dentro dos estágios de Sotigui, nunca são transmitidas com títulos, nem por meio de algum roteiro explicador. 0 roteiro que se segue é todo nascido da minha experiência na transmissão da prática. Dois atores sentam-se frente a frente, pernas cruzadas, corpo desperto, numa distância de aproximadamente 10 centímetros um do outro. Olhos nos olhos, um ator diz somente a palavra PRETO e o outro diz BRANCO. Não devem dizer simultaneamente as palavras, buscando recusar qualquer pressa. Ocupam-se em preencher o espaço todo com a sua cor, sem que um cinza se produza para o público. Dedicam-se cada um à sua cor, focados suavemente nela. Podem dizer nomes de outras cores também, mas há um rigor com a coincidência na quantidade de sílabas; em nossa língua, essa combinação me parece fértil. Minha experiência com essa prática costuma me apresentar um lugar em que abandono o 'falamos continuamente', meu monólogo interior se acalma, e já experimentei diferentes relações com minhas duplas, que não devem trabalhar como duplas em 
um jogo de cumplicidade. O 'estar junto' aqui acontece a partir de quem testemunha a experiência. Este é o desafio dos atores na cena, ao dizer 'preto' e 'branco', mantendo a conexão entre seus olhares. Há um rigor com a ocupação da presença de modo suave pelo espaço, talvez pela posição do corpo sentado que provoca, desde ela mesma, um repouso. Solicito que um participante não tente se impor, jamais, ao outro, nem procure ocupar um espaço maior, pois este dizer não é uma competição, mas é a manutenção silenciosa de uma só palavra ocupando, com seu sentido mais simples, o espaço entre os dois e entre todos os presentes. Reservando cada uma seu espaço a si, sem que se produza uma mistura para quem vê. Quando os lugares se mantêm preservados, ou seja, cada ator se mantém calmo, sem esforço para conquistar nem ocupar nada, somente inteiro em seu dizer dessa simples palavra, tenho, na platéia, a impressão de me acalmar junto com a dupla que adentra alguma quietude. Vivo também uma nítida sensação de que os dois ocupam cada um o seu lugar, tornando todo o espaço mais escutador do que se passa entre as coisas e pessoas ali presentes. Como se a prática convocasse todos a uma presença intensa, justamente por nascer da suavidade. Essa 'lógica’ ou, melhor dizendo, essa corporeidade de escuta está presente em tudo o que vivi com Sotigui Kouyaté nos estágios, e escorre para o fora dali também. Nos estágios ele não propõe uma grande quantidade de práticas, mas alterna exercícios como jogos com danças, cantos, relatos pessoais (dele), assistência de vídeos, conversas, muitas pausas para descanso, e, em estágios temáticos, leituras de textos (contos, teatro, poesia) e experiências de montagens de cenas. 
$\mathrm{Na}$ maior parte das vezes, a leitura dos textos (que irão para a cena) entra em continuidade à prática física. Mas o mais importante é que, seja pela repetição dessas práticas, seja pela entrada de outras da mesma natureza, o ator comece a conhecer esse lugar escutante em seu corpo, em seu estado, em sua percepção da possibilidade de receptividade quieta também para aproximar-se da palavra, na conexão sempre com qualquer trabalho que se venha a fazer com textos a serem lidos, ditos. Muitos atores entram em contato com esses seus lugares por meio de diversas experiências, advindas ou não do teatro, mas não os vinculam ao trabalho com o texto, e nisso insistimos incansavelmente.

Esse ator que escuta precisa, então, do silêncio, da quietude, da intensidade, do vigor e do brincar da poesia, precisa partir de outro solo que não o do excesso, o do fazer compulsivo, da proponência do profissionalismo, do preencher com boas ideias sua relação com a palavra. Deixar de dar o seu jeito, de trazer o seu melhor. Mas esperar até pelo que não é bom, por uma possível falta de jeito. E acalmar-se para a palavra. Encontrar o terreno do quieto para recebê-la, como quando se aprende a ler, como se cada uma das palavras lidas (mesmo as de um texto 'conhecido') estivesse sendo lida pela primeira vez. Acriançar-se diante da palavra, ter a curiosidade pelo que repousa ali. Livro ou papel, letra, tamanho da letra, espaço entre as letras, palavras, espaço entre as palavras, pontuações, frases lógicas, ilógicas, pedaços de frases, espaços entre as frases, tamanhos das frases, cheios e vazios do texto, das páginas. Alternar-se entre insistir em trechos e perceber o todo, não querer-dizer nada enquanto recebe. Burlar, de certa forma, o 'falamos continuamente'. 


\section{Um lugar para a duração}

\section{Mais rester toutes ces années}

\section{ami de toi-même}

\section{peut te donner la durée. ${ }^{43}$}

A partir da convergência entre três experiências pungentes vividas com o Tai chi chuan, o Butô-Ma e um trabalho coordenado pelo ator Yoshi Oida, tenho realizado trabalho para a palavra que insista na relação com o tempo a partir do perdurar de uma lentidão exagerada em nosso corpo. As experiências que me levaram a insistir na prática que aponto a seguir partiam, todas, da tomada do tempo no corpo num ritmo radicalmente lento. Elas me levaram a experienciar uma relação que passei a chamar de relação de duração com o tempo para a palavra, em oposição à relação de velocidade.

Talvez, nas experiências, o que tenha coincidido seja uma relação rítmica, imposta de fora pelos proponentes, que impunha sem perceber o que, para mim, veio a se mostrar como uma possibilidade de lidar com a duração no dizer de um texto lido. 0 uso dos princípios dessas experiências para encaminharmo-nos em direção ao texto veio da minha busca primeiro como atriz e em seguida com alunos e atores, no lugar de proponente. A relação delas com a palavra não existia. Eram práticas corporais.

Yoshi Oida, ator e diretor japonês, integrante do Centro Internacional de Pesquisa e Criação Teatral, em Paris. Experiência vivenciada em workshop, Fundação Calouste Gulbenkian, julho de 2001, Rio de Janeiro (RJ).

As práticas consistiam em executar ações cotidianas de maneira muito lenta: sair da posição de pé e sentar em 15 minutos; sair da posição deitada e ficar em pé em 30 minutos, por exemplo. 
Tadashi Endo, fundador do Butô Mâ. Experiência vivenciada em workshop em abril de 2003 em São Paulo.

Deitado, o ator colocava-se em estado de abandono ('o abandono de um bebê'), aberto a receber, na medida do possível, involuntariamente, a ação de virar-se no chão, como uma concha que é virada pelo mar. Porém, isso deve acontecer de maneira hiperlenta, e ele deve ser seu próprio vigia no aspecto involuntário da ação. Uma música bem lenta é colocada ou tudo é feito em silêncio. Variações possíveis: sentar, levantar, com o mesmo princípio. Depois, mudar para o movimento voluntário, e checar o que muda no corpo, na ação interna e externa.

Tai chi chuan, prática que aprendo desde 1994, e, no estilo Yang, desde 2001, no Rio de Janeiro e em São Paulo.

A prática a que me refiro na experiência com o lento foi vivenciada em um retiro em que realizávamos a forma tradicional desse estilo, que contém 103 movimentos normalmente realizada uma vez ou duas, com a duração de 15, 18 minutos cada vez -, numa sequência de três formas por cada vez, sendo que cada forma deveria durar 45 minutos, num total de 135 minutos, além de repetirmos cotidianamente quatro vezes essa mesma sequência. Algumas vezes fazíamos isso de olhos fechados.

Essas três experiências foram pungentes, em suas simplicidades, tanto quanto o foram aquelas relatadas no início dessa escrita com os livros que me moveram na direção da palavra (ou moveram-na em minha direção). Agregadas em seus (meus) pensamentos, originaram isto: 
Brincamos de ser 'donos do tempo' ao lidarmos com ações diversas em continuidade (sem nunca parar em seu percurso), a partir de um controle para que elas aconteçam de maneira lentíssima. Uma pessoa, ao entrar, deveria ter a impressão de que estamos parados, mas estamos em movimento contínuo hiperlento, sem pausas ou paradas. Na maior parte das vezes, quando vamos trabalhar o repouso sobre um texto que será lido, definimos a trajetória e o tempo que a ação lenta deve durar. Quanto mais curto o trajeto mais lento deve ser o percurso de um ponto a outro. Essa relação com o tempo do ponto de vista da duração - em oposição à nossa relação mais conhecida com o tempo sempre ligada à velocidade - dialoga com:

\section{HEXAGRAMA 32. HENG/DURAÇÃO}

A duração é um estado em que obstáculos não conseguem esgotar o movimento. Não é uma condição de repouso, pois a mera imobilidade significa na verdade um retrocesso. A duração é o movimento de uma totalidade organizada e completa em si mesma. Esse movimento está sempre se renovando. Ele se realiza segundo leis imutáveis e cada término dá lugar a um novo começo. 0 objetivo é atingido por um movimento na direção interna: a inspiração, a sístole, a contração. Esse movimento se transforma num novo começo tomando a direção externa: a expiração, a diástole, a expansão. (I CHING, s/d, p.111 $)^{44}$

O lugar des-encoberto a partir desse durar, tudo o que se abre de escuta a partir dele, pode ser, então, o nascedouro do dizer do texto. Em minha experiência dentro dessa prática na qual insisto muito, o que acontece nesse corpo em duração perdurante,

44 I CHING foi o livro indicado a mim, como praticante de Tai chi, sempre que manifestei aos professores a necessidade de ler algo 'sobre' a prática. 
frequentemente, é o imperar, de uma ofuscante clareza, do solo de silêncio onde nasce a palavra. Depois de passar pelo horror de contenção que o ritmo ultralento exige desse meu corpo apressado e barulhento - sacrifício muscular algumas vezes insuportável -, vivo uma amplificação da consciência do percurso da palavra dita (enquanto lida) ao passá-la dos olhos (origem) para a boca (primeira destinação antes da orelha, do ouvido). Percebo, na maior parte das vezes, com muita exatidão, sua trajetória: as bordas da boca como portal do meu dizer da palavra aprendida com os olhos, traçada pelo interno de meu corpo, ecoada nos abismos espaciais receptivos naquele momento ali dentro e destinada a um ouvir, a um dar-a-ver, a uma escuta que já me esperava, pois já me guiava antes mesmo de os olhos chegarem ao papel. Por isso insisto que o texto entre na continuidade do encontro com a duração, para que o aprendizado de alguma demora perdure.

Podemos, também, traduzir simplesmente, em palavras escritas, aquilo que estamos escutando dali, na continuidade da experiência física com a duração. Ou, ainda, podemos começar a dizer em palavras alguma coisa a um parceiro de trabalho. São duas outras possibilidades ligadas à palavra e ao dizer que também experienciamos, com menos frequência, para lembrar ao ator esse lugar de nascimento da palavra em seu corpo, de maneira mais direta, sem algo de fora para ser lido.

Antes de prosseguir nos vestígios de outras práticas, voltarei a alguns pensamentos que têm movido meu diálogo com elas, seja porque vieram antes, me empurrando para a insistência no tema, seja porque ajudam a aclarar os percursos, quando adentram nossos espaços de trabalho. 
As buscas dos principais formadores de ator no século XX dedicam-se ao tema. 0 trabalho de Jerzy Grotowski levou-o cada vez mais para dentro do mundo interior do ator, do homem:

Aqui não é lugar de colecionar todas as espécies de meios de expressão. (...) 0 primeiro dever do ator é aceitar o fato de que ninguém aqui deseja dar-lhe nada; em vez disto, pretendemos tirar muito dele, eliminar tudo que o mantém usualmente amarrado: sua resistência, sua reticência, sua tendência a esconder-se atrás das máscaras, os obstáculos que seu corpo impõe ao trabalho criativo, seus costumes, e até suas usuais ‘boas maneiras'. (GROTOWSKI, 1987, p. 217)

Sem jamais separar presença de distância, em “Uma arte esquecida” Peter Brook afirma: “distância é o compromisso com a significação total; presença é o compromisso total com o momento vivo. As duas caminham juntas." (BROOK, 1994a, p. 96) Ao dizer que a essência do teatro reside num “mistério chamado 'o momento presente”", Brook expande o tema, com advertências: “'O momento presente’ é surpreendente. Como o fragmento retirado de um holograma, sua transparência é enganosa. Dissecando esse átomo do tempo, vemos o universo inteiro contido em sua infinita pequenez." (BROOK, 1994b, p. 69) E prossegue:

O que importa para mim é que um ator possa permanecer imóvel no palco e prender nossa atenção, enquanto que outro não nos interessa nem um pouco. Qual é a diferença? Onde se encontra: num nível químico, físico ou psicológico? Qualidade para ser estrela, personalidade? Não. Isso é fácil demais e não se constitui numa reposta. Eu não disponho da resposta. Contudo, sei que está aí; nessa questão é que podemos encontrar o ponto de partida de toda nossa arte. (BROOK, 1994b, p. 307)

O ator lida, ao mesmo tempo, com a observação da própria presença, para que possa repetir, no futuro próximo ou distante, o presenciado no presente. Ele cria e repete. Deve expandir o que experienciou, tendo a possibilidade de aprofundar coisas, alterar o percurso a partir de uma re-visitação pelo que traçou num momento passado. E deve dar a impressão de que o vive pela primeira vez... Mas se a presença é pre-sença, conforme fomos levados a pensar anteriormente, a partir de algum repouso na 
etimologia da palavra, nenhum esforço é necessário. A observação também é presença e não outra coisa além dela.

Apesar da insistência no tema da presença por todos os que trabalham com o ator, o que me espanta nas impressões que geraram minha pergunta é ver o ator, muitas vezes, já começar a ler e a dizer o texto, desde sua primeira vez, a partir de um 'querer-dizer', de uma atribuição de significados e - por que não dizer? - de um excesso de vontade diante da palavra. Por isso busco derivar um pouco para este tema: o quererdizer. Esta deriva é sempre muito presente em minhas práticas com o ator.

Antes, porém, costumo fazer um alerta que gostaria de traduzir aqui. Partir da presença, de um estado de maior quietude e 'receptividade adequada' (Brook), para afastarmo-nos, num primeiro momento, de todo 'querer-dizer', não tem nada a ver com a busca de qualquer psicologização no campo desse trabalho. Ao contrário, se há um querer que se impõe aqui é o querer fugir das interpretações, das categorias, do que já é sabido pelo pensamento, pelo corpo, e nos impede a abertura para o mundo novo da palavra ali, aqui. Trata-se de uma conexão, insisto, com o presente da presença, e com tudo que é ausente aí. Para, então, dispor-se à palavra. Junto de Bachelard, num furto descarado para o que nos inter-essa, fui levada a pensar, para o ator, o que segue.

A exuberância e a profundidade de um poema são sempre fenômenos do par ressonância-repercussão. É como se, com sua exuberância, o poema reanimasse as profundezas de nosso ser. (BACHELARD, 1993, p. 8)

Ressonância: acontece quando escutamos. Dispersa-se nos diferentes planos da nossa existência. Aqui ouvimos a palavra.

Repercussão: acontece quando dizemos o lido. Convida-nos a um aprofundamento da nossa própria existência. Aqui a palavra é nossa.

0 ator que psicologiza está ensurdecido pelas ressonâncias e deseja incessantemente descrever seus sentimentos. 0 ator que psicanaliza perde a 
repercussão, ocupado que está em desembaraçar o emaranhado de suas interpretações, e intelectualiza a imagem. Ele a compreende mais profundamente do que o ator que psicologiza. "Mas precisamente, compreende-a. Para ele, a imagem tem sempre um contexto. Interpretando a imagem ele a traduz para uma outra linguagem." Se insistirmos um pouco mais, no que iniciamos páginas atrás, em que esse estado do ator diante da palavra tem algo da disponibilidade do poético, continuamos em coro com Bachelard para dizer:

Considerada na transmissão de uma alma para outra, uma imagem poética foge às pesquisas de causalidade. As doutrinas timidamente causais, como a psicologia, ou fortemente causais, como a psicanálise, não podem determinar a ontologia do poético. Nada prepara uma imagem poética: nem a cultura, no modo literário, nem a percepção, no modo psicológico. (BACHELARD, 1993, p. 8)

Em sua pressa em descrever, interpretar, desembaraçar o interpretado, entender, contextualizar, o ator quer. 0 ator quer capturar sentidos no lido e dito enquanto, ao mesmo tempo, dá a ver ao outro (ator, espectador) tudo o que o texto informa, já, em sua capa de afetividade decodificada como a melhor, a correta, a que deve melhor corresponder ao que 'o autor queria dizer' com aquela junção de palavras e frases. Ou aquela que melhor the serve para o que ele quer, então, dizer agora, para o que faz uso desse texto. Pode, ainda, ocupar-se, ao mesmo tempo - veja quanta pressa -, em bem corresponder às características daquele personagem que fala por ele ou em nome de quem ele diz o que diz. O tecido é complexo. Mas não tenhamos pressa.

Continuemos a lembrar o homem ao ator diante da ação de dizer o texto de um autor.

Novamente, com Peter Brook:

Insisto muito nisto porque existe um grande mal-entendido que bloqueia muito o trabalho no teatro. Consiste em acreditarmos que aquilo que o autor escreveu no papel é uma forma. Se pensarmos isso estamos completamente perdidos. (...) Tudo o que sabemos é que o autor escreveu uma cadeia de palavras que têm a possibilidade de originar 
formas incessantemente renovadas. Não há limites às formas virtuais que existem num grande texto.(...) Uma vez impressa, há a forma que é o livro. (...) Mas o que foi escrito e impresso não tem ainda a forma do que um dia poderá sair dessas palavras. Se dizemos 'estas palavras devem ser pronunciadas de determinada maneira, ter uma determinada cor, uma música...', infelizmente, ou talvez felizmente, enganamo-nos sempre. Isso leva-nos ao que há de pior na tradição, no mau sentido da palavra. Somos constantemente surpreendidos pela quantidade de formas inesperadas que podem surgir dos mesmos elementos e a tendência humana para as recusar representa sempre a redução de um universo. (BROOK, 1993, p. 68)

Convidemos, ainda, outras palavras sobre o tema.

$\mathrm{Na}$ conferência "assinatura acontecimento contexto", Jacques Derrida ${ }^{45}$ diz que lidar com o escrito é lidar com o ausente. Com a ausência de destinatário e com a ausência do emissor, do destinador.

Um signo escrito cria-se na ausência do destinatário. (...) Para que um escrito seja um escrito, é necessário que continue a 'agir' e a ser legível mesmo se o que se chama o autor do escrito não responde já pelo que escreveu, pelo que parece ter assinado, quer esteja provisoriamente ausente, quer esteja morto ou que em geral não tenha mantido a sua intenção ou atenção absolutamente atual e presente, a plenitude do seu querer-dizer, mesmo daquilo que parece ser escrito 'em seu nome'.

Leitor e escritor, e, em nosso caso, ator e autor, estão na mesma situação. 0 ator nunca terá, como afirma Derrida sobre o leitor, "o conjunto das presenças que organizam o momento da inscrição do escrito". Se retornamos ao início de sua conferência, podemos afirmar então que, para ele, comunicação não é "o veículo, o transporte ou o lugar de passagem de um sentido e de um sentido uno".

Torcer as palavras, auscultá-las para perceber seu segredo, ir até o limite para, no fim, dar o que não se tem. Pois "somente aquele que não sabe ler pode dar a ler. Aquele que já sabe ler, aquele que já sabe o que dizem as palavras, aquele que já sabe o que o texto significa...esse dá o texto já lido de antemão e, portanto, não dá a ler.” (LARROSA, 2004. p. 20)

$\overline{45}$ DERRIDA, 1991. Os trechos a seguir são das páginas 349 e 356-358. 
"auscultando...pertence $=$ hoerend... gehoert: aqui se faz referência à interdependência dos dois verbos, hoeren (ouvir, auscultar) e geroeren (pertencer), a um mesmo radical." 46

${ }^{46}$ HEIDEGGER, 1995, Ver, no livro, nota de rodapé no 12, p. 29. 
Aqui, pensamos o ator como esse sujeito que não tem vontade de domínio, de propriedade, que suspende $\mathrm{o}$ saber e a intenção. 0 ator que aceita a palavra que despenca, a perda de seus sentidos conhecidos de antemão (do ator, das palavras), que se dispõe para auscultar o lido, auscultar enquanto diz. Perde a soberania tão característica de sua posição (um sujeito que opta, que escolhe, que significa) e aceitase num lugar de indigente. E nesse lugar, diante do texto, despenca também a noção de comunicação mais conhecida e fazemos coro ao traço de Derrida. Despenca junto o modo como se dá essa comunicação. Seu lugar não é o de sustentar o transporte linguístico de um 'querer dizer' do autor, do texto. Aquilo que o autor nos deixa (a não ser que ele esteja presente nos ensaios, mas não é disso que nosso texto trata) é somente uma sequência de palavras, dentro de frases e, no caso ainda da maior parte dos textos dramatúrgicos, frases dentro de períodos divididos por personagens. Se no dar a ler do escritor devemos ler sua ausência e o fracasso de seu 'querer dizer', quando o escritor dá a ler não se coloca a si mesmo para relacionar-se por meio da escritura com um leitor mais ou menos antecipado, nem tampouco dá a ler simplesmente o que suas palavras 'dizem' ou 'querem dizer'.

O escritor dá a ler as palavras no mesmo movimento que as abandona a uma deriva na qual nem ele nem suas intenções estarão presentes e que ele, naturalmente, não poderá nunca controlar. As palavras que se dão a ler não unem o escritor com o leitor, mas os separam infinitamente em uma 'eternidade sem consolo'. (...) Então, não é o escritor aquele que dá a ler, mas é a escritura mesma que se dá a ler na desaparição do autor, não na presença de seu 'querer dizer' ou de seu 'querer comunicar'. (LARROSA, 2004. p. 20)

$\mathrm{Na}$ fidelidade ao nosso tema (a relação do ator com a palavra escrita, com um texto lido e posto em cena), o ator começa o trabalho como um leitor. Um leitor que dará a ler, e mais, que dará a ver a anterioridade das palavras do texto. 
A teatralidade não está no texto. Ela é a vinda do texto ao olhar. Ela é este processo pelo qual as palavras saem de si mesmas para produzir o visível. A teatralidade é o próprio pôr/em/cena. (...) Ator e autor são os dois pólos fundadores do teatro: pólo verbal, literário, textual e pólo físico, corporal, exposto à vista. (GUÉNOUN, 2003. pp. 55-61)

Se o ator é a fonte dessa passagem, torna-se o autor da palavra que será vista/ouvida pelo público. Mesmo que, num limite, ele tenha em mãos um livro e explicite a sua fonte, dizendo: 'Isso que eu direi agora é de Shakespeare: ...', é ele, o ator, quem diz ali, em exposição, quem dá voz ao escrito anterior do outro, ausente. 
Enquanto isso, em meu ouvido, Novalis monologa, romanticamente, segurando sua flor azul:

"O que se passa com o falar e o escrever é propriamente uma coisa maluca; o verdadeiro diálogo é um mero jogo de palavras. Só é de admirar o ridículo erro: que as pessoas julguem falar em intenção das coisas. Exatamente o específico da linguagem, que ela se aflige apenas consigo mesma, ninguém sabe. Por isso ela é um mistério tão prodigioso e fecundo - de que quando alguém fala apenas por falar pronuncia exatamente as verdades mais esplêndidas, mais originais. Mas se quiser falar de algo determinado, a linguagem caprichosa o faz dizer o que há de mais ridículo e arrevesado. Daí nasce também o ódio que tem tanta gente séria contra a linguagem. Notam sua petulância, mas não notam que o desprezível tagarelar é o lado infinitamente sério da linguagem. Se apenas se pudesse tornar compreensível às pessoas que com a linguagem se dá o mesmo que com as fórmulas matemáticas - Elas constituem um mundo por si - jogam apenas consigo mesmas, nada exprimem a não ser sua prodigiosa natureza, e justamente por isso são tão expressivas - justamente por isso espelha-se nelas o estranho jogo de proporções das coisas. Somente por sua liberdade são membros da natureza e somente em seus livres movimentos a alma cósmica se exterioriza e faz delas um delicado metro e compêndio das coisas. Assim também com a linguagem - quem tem fino tato para seu dedilhado, sua cadência, seu espírito musical, quem percebe em si mesmo o delicado atuar de sua natureza interna, e move de acordo com ela sua língua ou sua mão, esse será o profeta; em contrapartida, quem sabe bem disso, mas não tem ouvido ou sentido bastante para ela, escreverá verdades como estas, mas será feito de palhaço pela própria linguagem e escarnecido pelos homens, como Cassandra pelos troianos. Se com isso acredito ter indicado com a máxima clareza a essência a função da poesia, sei no entanto que nenhum ser humano é capaz de entendê-lo e disse algo totalmente palerma, porque quis dizê-lo, e assim nenhuma poesia resulta. Mas, e se eu fosse obrigado a falar? e se esse impulso a falar fosse o sinal da instigação da linguagem em mim? e minha vontade só quisesse tudo a que eu fosse obrigado, então isso, no fim, sem meu querer e crer, poderia sim ser poesia e tornar inteligível um mistério da linguagem? e então seria eu um escritor por vocação, pois um escritor é bem, somente, um arrebatado da linguagem?" (NOVALIS, 1988, p. 76) 
A separação das práticas em lugares só serve para essa escrita. Ela é a tentativa de traçar um contorno para o lugar da escuta, para a escuta em si, para o que essa palavra tem aberto de sentidos para nós, em nossos corpos, e entre nós. Este 'nós' refere-se a mim e aos meus parceiros com os quais, juntos, partilhamos as chegadas no que venho nomeando por aqui como um lugar escutante. Não me aconteceu de nomeá-lo como escutador. E disso só me apercebi ao escrever. Talvez seja o lugar mesmo que esteja se nomeando assim, ou que tenha já se nomeado assim, pois é assim que o chamo perto dos corpos vivos. Dizer 'escutador' é imprimir alguma ação, algum fazer. E, neste lugar, receber está sempre sutilmente à frente de qualquer agir.

$\mathrm{O}$ ator, ele mesmo, encontra o lugar escutante em si, entre nós. Ou é encontrado por ele. Dou uma ou duas mãos somente para lembrá-lo da escuta em si, assim como recebi e recebo outras mãos para chegar no meu.

O lugar do ator é dele, não é meu. "Ninguém dá a você aquilo que você não tem." ${ }^{47}$

No dia 12 de abril de 2003 levei a peça Madrugada, na qual estava em cena sozinha, para a Casa das Palmeiras, fundada por Nise da Silveira, dirigida à época por Walter Melo, no Rio de Janeiro. A Casa das Palmeiras é uma clínica de reabilitação para egressos de instituições psiquiátricas, em regime de externato, que utiliza atividades artísticas e artesanais como principal método terapêutico. Em 2003, todas as quartasfeiras a Casa recebia alguma peça de teatro. Naquele 12 de abril 38 pessoas inventaram de fazer, em papéis rasgados, um ingresso numerado e todo escrito à mão, contendo o nome da peça e um número no canto superior direito, para também inventarem uma fila e adentrarem na casa que cotidianamente ocupavam, para 'me assistirem'. Queriam

\footnotetext{
${ }^{47}$ Fala repetida por Sotigui Kouyaté nos estágios de 2002, 2003, 2006, 2008.
} 
fazer 'como era no teatro' fora dali. Começava nosso jogo, nossa vida juntos (que duraria somente 4 ou 5 horas), e um lugar novo (uma vida nova) que eu conheceria em mim. Tenho medo de escrever em detalhes o que vivi ali e perder em meu corpo o vivido, ficando com a memória desse escrito e desse lido enquanto (e depois de) escrito. Percorri a trajetória conhecida da cena, com derivações que duravam algumas vezes muito tempo, outras eram só relâmpagos de chamados para nossas digressões, juntos, às margens daquela 'peça'. Aquilo já não era mais uma peça, ao menos não era a peça que eu conhecera até aquele dia - e já apresentava o trabalho havia três anos. Numa deriva, fui convidada a conversar sobre a Floresta Amazônica, tema proposto por um homem da platéia, e aceitei seu convite. Depois retornei à 'peça'. Outra pessoa entrou em cena, pegou um de meus objetos e levou-o embora, saindo do espaço de trabalho, enquanto me contava sobre a 'xoxota' de sua tia, que estava 'dentro de uma xícara'. Ela tomava muito remédio, era visível, e tremia demais o tempo todo. Outro homem escreveu (e leu) um texto ao final da 'peça' sobre 'Madrugada e a ilha de Paquetá', espaço nunca citado em nenhum momento da peça. Um ex-paciente da Casa ficou extremamente contente quando eu disse pensar que ele fosse psiquiatra ou terapeuta, e me presenteou com um livro que escreveu com Rubens Correa, Nise da Silveira e Marco Lucchesi sobre Artaud. ${ }^{48}$ Depois da 'apresentação' - a peça costumava durar 50 minutos e neste dia durou quase 90 - tivemos algumas horas de conversa. Uma conversa que, para mim, não era outro momento, além da peça, ou depois da peça: era a mesma trajetória que continuava desde a feitura dos ingressos, desde a fila, desde a entrada de todos, desde nossa Madrugada vespertina, desde esse papo... Cheguei em minha casa e fiquei acordada, deitada, sem me mover por aproximadamente duas horas (coisa só percebida com a chegada de meu marido, que me 'despertou'). Deve ter sido um desaquecimento que se ofereceu, se impôs. Um mês depois, fui convidada, pelo diretor da casa e

\footnotetext{
${ }^{48}$ O livro era LUCCHESI, Marco (Org). Artaud, a nostalgia do mais. Rio de Janeiro, NUMEN, 1989.
} 
algumas de suas parceiras de outras instituições psiquiátricas cariocas, para dirigir um grupo, formado por 'usuários de saúde mental' e por terapeutas dessas quatro instituições, pois eles diziam "nunca ter visto, em nenhuma peça que assistiram na Casa das Palmeiras ou no Museu do Inconsciente, uma pessoa tão aberta para os pacientes, tão aberta para tudo que acontecesse ali, na hora". Este foi o convite mais precioso que recebi na minha vida. E eu sabia, ali, que havíamos, todos, vivido uma 'primeira vez'. Não fui eu quem me abri, foi o encontro que revelou uma abertura possível que me estava sendo apresentada ali, daquela maneira, naquela profundidade, naquele momento. Por isso, tenho certeza, ela (a abertura doada pelo encontro dos presentes) pediu aquele enorme repouso em seguida. Porque era um nascimento o que se dava em mim, no entre-nós. Fundamos juntos o Espaço Artaud, mas eu retornei a São Paulo e nunca pude dizer 'sim' ao convite. E, talvez, seja esta impossibilidade que, junto de todas as alianças que determinam minhas buscas, me oriente para insistir tanto na visita ao lugar da escuta. 
“Todas as coisas pequenas exigem vagar.” (BACHELARD, 1993, P.167) 


\section{Um lugar para a miniatura, receptivo ao pequeno, ao detalhe}

A partir de um lugar silencioso (re-)conhecido em nosso corpo, lugar que recebe as palavras do texto, podemos entrar em contato com o que diminui em nós ao aproximarmo-nos da palavra, quando a dizemos sem impormos nossos 'quereres' nesse dizer o lido. Diminuímo-nos diante do texto, pois nossas vontades estão menos proponentes no que se passa entre nós: palavra lida e corpo. Assim, temos a chance de ver o pequeno do texto, os detalhes, os sentidos (ou as direções) talvez nunca vistos ou esquecidos. Este lugar receptivo ao detalhe nasce, e só é possível, a partir de alguma quietude. É um outro nome para lembrarmos do pequeno, do pormenor do que se passa entre nosso corpo e a palavra vinda de fora. Alguns gestos em espaço de trabalho podem 'instalar' a miniatura. Mas eles só interessam, aqui, quando dialogam de algum modo com nossa relação com a palavra. Com o grupo Jogando no Quintal, experienciamos, em 2006, viver a miniatura assim: cada pessoa do grupo deveria levar, para o dia do trabalho, um objeto minúsculo, o menor que encontrasse. Escrevi um dos trechos ressonantes aqui, de Gaston Bachelard, em letras minúsculas sobre um grande papel em branco: "A miniatura é uma das moradas da grandeza". Todos os participantes desenharam, em folhas em branco ${ }^{49}$ e com uma caneta somente, um lugar escolhido de sua infância. ${ }^{50}$ Depois, em outra folha branca, deram nomes a esse lugar, ao que deriva do lugar. Enquanto isso, eu criei uma instalação no canto da sala, bem no cantinho, escondida atrás de uma cortina e em local muito baixo (que obrigasse o corpo a abaixar até muito perto do chão para mirar): nela havia todos os objetos trazidos pelos atores/palhaços/músicos sobre o solo branco, que continha em um de seus cantinhos as palavras da frase de Bachelard. Quando todos os integrantes do grupo terminaram de dar

\footnotetext{
${ }^{49}$ Tenho gostado das folhas totalmente brancas, elas escutam mais do que as coloridas, ou do que as que têm linha.

${ }^{50}$ Aqui estão presentes algumas experiências - Jardim da infância e técnica da Escrita total - realizadas na disciplina de pós-graduação Jornalismo Literário avançado e Histórias de Vida, coordenada pelo Prof. Dr. Edvaldo Pereira Lima do CJE-ECA-USP, que cursei em 1999.
} 
“O homem da lupa não é aqui o velhinho que ainda quer, apesar dos olhos cansados de ver, ler o seu jornal. O homem de lupa toma o Mundo como uma novidade. (...) O homem de lupa barra - simplesmente - o mundo familiar. É um olhar novo diante de um objeto novo. A lupa do botânico é a infância redescoberta. Ela devolve ao botânico o olhar engrandecedor da criança. (...)

Assim, o minúsculo, porta estreita por excelência, abre um mundo. O pormenor de uma coisa pode ser o signo de um mundo novo, de um mundo que, como todos os mundos, contém os atributos da grandeza.

A miniatura é uma das moradas da grandeza." (BACHELARD, 2005, p.163) 
os nomes a seus lugares de infância, pedi que eles escrevessem um texto, em escrita livre, sem interrupções, sem correções, a partir, cada um, de seu desenho e de sua folha de nomes. Ao terminarem, um a um poderia ir visitar o lugar das miniaturas. Sempre sozinho, sempre se demorando ali.

A possibilidade que se acena num encontro como esse é, do meu ponto de vista, a percepção, em espaço de trabalho prático, do lugar do pequeno (e de alguma grandiosidade nascida dessa diminuição) em nossos próprios corpos. A percepção do assombro diante do minúsculo, do reduzido. E aqui vejo, a partir também de outras experiências que conduzo a partir de formas análogas a esta, a possibilidade de diálogo entre o conhecimento (pela consciência serena) deste lugar em nós e a entrada da palavra de um outro para tornar-se um dizer próximo, e aproximador. 


\title{
Um lugar para olhar para trás
}

\author{
Pouvoir penser à l'enfant \\ que j'ai été \\ c'est déjà le retrouver. ${ }^{51}$
}

Como venho dizendo, todos esses lugares são um mesmo, com sutis percepções e nomes para reconhecer a escuta mais plena em nós mesmos. Para cá trago o tema de algumas práticas que tratam de lembrar o que está atrás do dito, atrás de nós. Para alguma conexão com o que olha para trás em nosso corpo, retomo outras experiências acontecidas no workshop de Tadashi Endo, que se mistura novamente à minha prática do Tai chi chuan e à elaboração da prática trazida pelas leituras do I Ching (ver nota 43). Tudo isso se mistura com as outras alianças que a vida me ofereceu: com o Palhaço, com seu corpo escutante nos $360^{\circ}$ que o rodeiam, com as leituras que também pediam um contato com o que, na presença, não se esquece do que já foi. As práticas que tentam trazer alguma rostidade às nossas costas, que tentam levar também os nossos olhos para trás da cabeça, para a nuca vêm sendo:

\section{HEXAGRAMA 52. KÊN/A QUIETUDE (MONTANHA)}

Alternância entre repouso e movimento, na relação com a percepção do tempo/impulso. "O hexagrama representa o fim e o começo de todo movimento. As costas são mencionadas porque nelas se encontram todas as fibras nervosas mediadoras do movimento. Quando estes nervos dorsais são postos em repouso é como se as inquietudes desaparecessem. Quando o homem alcança essa tranquilidade interior pode se dirigir ao mundo externo e já não verá mais nele a luta e o tumulto dos seres individuais." (I CHING, s/d, p.161)

\footnotetext{
${ }^{51}$ HANDKE, 1987. p. 26.
} 
Permanecer vendado ou de olhos fechados por muito tempo, com ou sem movimento, com ou sem algo para ser feito (improvisação, ações físicas partiturizadas, relação com objetos), no escuro ou no claro. E, depois de qualquer uma delas - em seguida, em continuidade, sem quebras -, receber o texto, ler o texto, dizer o texto.

Escrever textos a partir dos motes como: eu tenho saudade (um texto todo escrito a partir daqui), ou os espaços que conheço (um texto todo escrito a partir daqui), um fato marcante vivido (um texto todo escrito a partir daqui), enfim, todos impulsos que levem a um 'olhar para trás'. Em seguida a essa escrita fundada na história pessoal começamos a ler e dizer o texto a ser encenado.

Lembrar-se de si criança (e olhar para trás concretamente, realizando o gesto, sempre que necessário for, para 'vê-la' atrás de si) ao ler e dizer um texto.

Com as costas nuas, um ator realiza, com suas mãos, toques suaves na pele das costas do outro e, depois, recebe daquele que foi tocado. Numa variação, os toques podem ser mais fortes, mais intensos, como, por exemplo, o movimento de amassar a carne do outro, ou friccionar sua mão num ritmo mais rápido nas costas do outro etc. E, depois - em seguida, em continuidade, sem quebras -, receber o texto, ler o texto, dizer o texto.

Dois atores encostam suas costas inteiras. Digo: 'nas costas está o seu rosto, com todos os detalhes que existem no seu rosto, marcas, afundamentos, protuberâncias. Seu rosto está ali.' Esta prática acontece depois de uma preparação física muito intensa, que deve trabalhar a musculatura profunda do 
corpo todo e disponibilizar as pernas para um longo trabalho sobre a base, para o qual ela será exigida com vigor. Com esses 'rostos' colados, os atores devem adentrar um no rosto do outro, inicialmente com suavidade, depois com intensidade mais sanguínea. Podem evoluir o encontro para uma dança, podem começar a se descolar, sempre retornando ao contato. Algumas vezes, depois que os corpos se separam, conduzo-os a escolher um lugar da sala para imprimir este rosto, colando-o lá e daí, a partir daí, levo o texto até eles. Mas, sempre, com ou sem esta etapa do imprimir, o texto aqui também deve chegar em continuidade, sem quebras, para ser lido, para ser dito.

“As costas chamam quase sempre ao decifrar e à hipótese: aqui, nada é certo. Elas se impõem como massa física, sem olhares molhados nem bochechas cavadas. 0 discurso das costas está sempre por ser inventado. Resposta que fica para o Ocidente como uma interrogação, mesmo que seja uma interrogação marginal. 0 Homem de costas exige o direito ao segredo, o qual ele não aceita nem que seja desvendado, nem deflorado, e este fechamento sobre si mesmo motiva a atração que as costas exercem. Por que Joyce gostava, mais do que qualquer outra, da única foto na qual o vemos de costas? "É preciso que um homem esteja escondido para que possamos amá-lo; desde que ele mostra seu rosto, o amor desaparece," confessava Ivan Karamazov." (BANU, 2001, p. 158) 


\section{Um lugar para a escuta da pele, dos poros}

$\mathrm{Na}$ etimologia de poro (orifício do corpo) encontramos o que se segue, como já dissemos na delimitação de nosso campo: nópos (do grego poros) = ação de passar, travessia; passagem, via de comunicação; leito dum rio, leito do mar, mar; estreito, ponte, via, caminho; conduto $^{52}$. Na prática com o que nomeio a escuta da pele, insistimos, mais uma vez, num corpo escutante, com alguma radicalidade.

Pensamos em experienciar a aproximação do texto como experienciamos a investigação sobre os ossos, os músculos, os espaços dentro do corpo, a pele. Procurar não separar 'o momento do corpo, da palavra solta, das vocalidades' do 'momento do texto, das compreensões, dos entendimentos'. 0 trabalho do ator dá-se muito com separações: corpo, improvisação, palavra improvisada, investigação com a expressão vocal, pesquisa com sonoridades, qualidades de movimento aplicadas à palavra. Depois de uma pausa, passa-se então às leituras do texto; e, junto, aos estudos do texto. Ou começa-se por ler o texto, por entender o que se diz ali, para, então, ir para a improvisação e para experimentações longe do que está dado como escritura. Aqui queremos nos amigar do escrito. Amigarmo-nos do lido. Permanecer por mais tempo aqui. Perto do papel. A partir da pele.

o laboratório dramático do ator, proposto por Antonio Januzelli $i^{53}$, conforme recebi em aulas já referenciadas aqui, e em trabalhos que desenvolvemos em parceria -, insiste na fricção entre as peles, entre os corpos, para que o fogo do corpo dramático seja acendido, despertado. Vivenciei outras experiências advindas do ambiente teatral que insistem também na pele como órgão despertador da escuta, além do que a vida nos ensina sobre essa potência em sua obviedade mais superficial ou profunda. Disso nasceu a prática inventada a seguir, que tem se revelado um dos espantos maiores nos relatos

\footnotetext{
${ }^{52}$ A partir de: PEREIRA, 1998.

${ }^{53}$ Aqui procuro usar terminologia que escutei dele.
} 
dos atores e alunos com quem venho trabalhando. Espanto pela necessidade de silêncio exigida por ela e espanto pela intensidade de abertura para a escuta que oferece:

A prática é feita sempre em grupo de quatro a seis pessoas. Todos devem estar com pouca roupa, de preferência um biquíni para as mulheres e uma sunga para os homens. Uma pessoa de cada grupo fica no centro, de olhos fechados, e as outras ficam bem perto dela, em roda, de olhos abertos. Quatro movimentos serão feitos no sentido de despertar a pele do ator que está no centro. Todas as mãos de fora devem tocar ao mesmo tempo a pele do parceiro para executar as ações. São ações de colocar terra, fogo, ar e água no corpo do parceiro. Não há nada nas mãos de ninguém. São gestos fundados nas qualidades desses elementos. Colocar terra traduz-se em gestos de 'aterrar' com fixidez e pontuação as mãos sobre o corpo do parceiro, como se um pouco de terra úmida fosse colocada a cada vez e ali devesse repousar. Colocar fogo traduz-se em gestos de fricção circular e com bastante intensidade, produzindo calor. Colocar ar consiste em produzir leve brisa ou vento perto da pele de quem está no centro, usando as mãos, ou alguma peça de roupa, ou assoprando. Banhar a pessoa com água é somente um leve gotejar: com as pontas dos dedos em gestos muito suaves e rápidos, toca-se a pele toda do ator. Todas as ações devem começar na cabeça e descer para os pés, sem deixar nenhum terreno da pele sem receber toque; e mesmo os pedaços de pele que estão cobertos devem ser movidos e tocados com delicadeza. Por fim, uma última ação é solicitada: os integrantes da roda devem colocar sons no corpo do parceiro, tocando a pele dele com a própria boca, reverberando, escutando o que ali é doado. Ao final de cada trabalho, um outro ator vai para o centro da roda, até que todos tenham recebido todas as cinco ações em sua pele. Oriento os atores para que se percebam em trabalho com os elementos e com os sons o tempo todo, seja doando, seja recebendo. Ao final, ninguém deve falar, preferencialmente, até ir dormir neste dia. Então, muitas vezes, 
esta é uma prática que deve ser feita à noite ou com algum planejamento para que o ator possa realmente ficar algumas horas sem falar.

“A língua latina e a língua grega assinalam, cada uma delas, duas formas de silêncio, respectivamente: (tacere) o silêncio que fala de uma paragem ou de uma ausência de palavra relacionada a alguém; (silere) o silêncio que se aplica às pessoas e também à natureza, aos objetos e fala de uma "tonalidade agradável da presença que não é perturbada por nenhum ruído"; (siôpân) o calar-se (mergulhar no silêncio) e (sigân) o estar calado. (...) O silêncio nunca é o vazio, mas um sopro entre as palavras. (BRETON, s/d, p.23)

Aqui busco radicalizar uma experiência com a escuta da pele como via de acesso para o que venho nomeando lugar escutante, agora intensificado pelo que nos envolve concretamente, o que nos cobre mas ainda preserva abertura, a abertura dos poros, condutos que ligam os espaços dentro e fora de nós. A pele, nosso maior órgão externo, é dinamizada em muitas práticas teatrais; esta, que citamos acima, pode ser realizada, depois, também em etapas, para relembrar a pele como órgão escutante ao ator, em tempos mais curtos, somente com um ou dois elementos por vez, por exemplo. 


\section{Um lugar para andar a caminho, possível abertura para pensar}

\section{'experiência'}

Tratar as costas como um rosto já traz um caminhar. Traz o caminhar do que está atrás, que se conecta ao que está à frente. A presença pode ser amplificada a partir de uma minoração: caminho que vimos percorrendo. Engrandecer porque diminuiu. Simples assim, como o caminho de todo ser vivo. Viver caminhadas antes do dizer um texto quer trazer ao ator a percepção do texto em sua trajetória contínua, quer oferecer ainda a serenidade da consciência dos pares abandono/apropriação, passado/presente, vivo/morto, vida/morte, frente/trás, lado/lado, acima/abaixo, escuridão/clareza, grande/pequeno, manifesto/imanifesto. Eles não cessam aqui, assim como são infinitas as caminhadas a serem experienciadas.

Três caminhadas nas quais temos insistido como lugares escutantes para um dizer são:

$>0$ ator caminha em direção a uma cartolina branca na qual escreveu seu nome completo, sua data de nascimento, a data da experiência e o tempo vivido até o presente dia. Por exemplo : sou Juliana Jardim Barboza, nasci no dia 3 de outubro de 1967 e vivi até hoje, dia 25 de maio de 2009, 41 anos, 7 meses e 22 dias. 0 ator deve posicionar-se a uma distância de 5 a 8 metros da cartolina (ou quanto o espaço permitir), olhando-a frontalmente, lendo o que está ali escrito durante todo o seu percurso ou, ao menos, mantendo-se conectado ao que está ali. A caminhada deve ser muito lenta, ele desliza os pés inteiros no chão, puxados pelo dedão do pé. Depois de chegar à cartolina, ele fecha os olhos e, sem muita demora, é aqui que o texto deve chegar, em continuidade, sem quebras, para ser dito. 


\section{Caminhadas experienciadas, como algo próximo disto, com Tadashi Endo ${ }^{54}$.}

Após uma intensa e rigorosa preparação da musculatura profunda e especialmente do abdômen, o ator percorre uma caminhada em que são exigidas expansões e contrações do corpo todo, com enorme comprometimento de tensão muscular. Tudo deve ser executado sem nenhum relaxamento, sempre em hiper-tensão. Normalmente trabalho com música nessa trajetória, pois a alta exigência de força muscular pode ser aliviada se o ator dedica-se a dançar o que ouve, não se ocupando demasiadamente da dor. 0 ator dança no detalhe, no pequeno, no menor do menor de seu comprometimento muscular, aquilo que vive ali em seus músculos, pelo que eles exigem. Ele deve alternar-se entre engrandecer (expansão) e diminuir (contrair) seu corpo, sempre em direção ao centro de seu corpo, o ponto entre o umbigo e o sexo. Seu destino é ir para frente de onde começou, também, se possível, percorrendo uma trajetória de 5 a 8 metros. Ao chegar ao endereço de destino, o texto deve ser recebido, em continuidade, sem quebras, para ser dito.

O ator caminha com seus pés totalmente colados ao solo, deslizando, a passos lentos, sem paradas. Sempre em continuidade. Seus olhos estão conectados com o 'atrás de si', mas ele nunca deve perder-se do endereço, do lugar para o qual caminha, sempre seguindo para frente. Ao começarmos, cada um deve colocar uma foto sua, quando criança, sobre a cabeça. Mas esta foto não está ali. Ela é um papel em branco que todos colocam sobre suas cabeças. A folha pode cair no percurso, ele não deve se ocupar em mantê-la imóvel. Lembro-o, ao começar: que seus olhos olham para trás, estão nas costas, na nuca, atrás da cabeça, nos

${ }^{54}$ Ver página 72. 
calcanhares, onde ele quiser, mas para trás; e que a caminhada é sobre mortos, ‘abaixo de seus pés, há mortos'. Ao chegar no final de seu trajeto, o texto deve começar a ser lido e dito em continuidade, sem quebras.

“Fazer uma experiência com algo, seja com uma coisa, com um ser humano, com um deus, significa que esse algo nos atropela, nos vem ao encontro, chega até nós, nos avassala e transforma. 'Fazer' não diz aqui de maneira alguma que nós mesmos produzimos e operacionalizamos a experiência. Fazer tem aqui o sentido de atravessar, sofrer, receber o que nos vem ao encontro, harmonizando-nos e sintonizando-nos com ele. É esse algo que se faz, que se envia, que se articula. (...)

Fazer uma experiência significa literalmente eundo assequi: no andar, estando a caminho, alcançar uma coisa, andando, chegar num caminho. (...) Fazer uma experiência com alguma coisa significa que, para alcançarmos o que conseguimos alcançar quando estamos a caminho, é preciso que isso nos alcance e comova, que nos venha ao encontro e nos tome, transformando-nos em sua direção."

(HEIDEGGER, 2003, p. 130) 
As palavras - imagino isso freqüentemente - são casinhas com porão e sótão. 0 sentido comum reside no rés-do-chão, sempre pronto para o 'comércio exterior', no mesmo nível de outrem, desse transeunte que nunca é um sonhador. Subir a escada na casa da palavra é, de degrau em degrau, abstrair. Descer ao porão é sonhar, é perder-se nos distantes corredores de uma etimologia incerta, é procurar nas palavras tesouros inencontráveis. Subir e descer nas próprias palavras é a vida do poeta. Subir muito alto, descer muito baixo é permitido ao poeta que une o terrestre ao aéreo. (BACHELARD, 2005, p. 155)

A prática de escavação da palavra parte de um exercício bastante tradicional e simples: começamos a dizer um texto, uma frase, lendo-a ou não. Se começarmos lendo, devemos sair do lido, tão logo a frase more em nosso dizer, sem esforço. Começo as escavações por trechos muito curtos, mas que tragam, desde sua escolha, algum sentido para quem o diz. Quem diz, escolhe o que dirá. A experiência busca aproximar o dizente daquilo que ele diz, por meio da escuta que se dá entre guia e dizente, ambos receptivos à percepção de onde aquele dizer acontece. As experiências são absolutamente únicas - elas sempre o são -, mas aqui posso trazer algum vestígio do que me acontece, do que espero e do que persigo, ao me colocar nesse lugar de guia para um escavar que começa como o de outro, mas passa a ser nosso.

Em busca das etimologias ${ }^{55}$, localizamos que a palavra mestre é um derivado do latim magister: "O que sabe mais, o melhor". Esse sentido nunca me convidou. Chegamos, então, ao termo guiar:

Tem origem provavelmente no germânico witan. Seu sentido originário implicava 'juntar-se', 'ir com alguém'. No direito feudal era utilizado para referir-se ao fato de escoltar alguém para garantir sua segurança. Em português, implica o labor de mostrar o caminho para chegar a algum lugar e, no plano abstrato, para alcançar um conhecimento. Em latim esse campo semântico está coberto por ducere.

\footnotetext{
${ }^{55}$ Todo este trecho das etimologias citadas está em CASTELLO e MÁRSICO, 2007, pp. 35, 43, 63, 102.
} 
0 ator como um guia sem vontade de domínio, que guia só pelo fato de ir junto com alguém (consigo mesmo, com o texto, com o outro ator, com o público), põe no mundo a palavra que recebe-e-dá, protegendo-a enquanto deixa que ela parta para viver no aberto dos sentidos. 0 guia do ator neste mesmíssimo lugar.

Trata-se de um repouso para pensar este guiar. Expandimos a parada. Supõe-se que educare provenha de "educere, composto de ex e duco, que significa 'fazer sair', 'tirar para fora' e, por extensão, 'pôr no mundo', no sentido de 'tirar do ventre da mãe' e, em alguns contextos, 'criar ou 'educar' uma criança”. Já transmitir "deriva de 'transmittere', um composto do verbo latino mittere, cujo significado original remete à idéia de 'deixar ir', 'lançar' e, a partir daí, ‘enviar’”. A preposição trans indica 'mais além’.

As escavações são repousos, permanências, insistências, subidas e descidas nas palavras, de modo corpóreo, sem aplicar sobre elas nenhuma forma, mas, a partir de todos os lugares experienciados como escutantes, dizê-las até encontrar o fundo, o enraizamento do dizer em si, o vigor escutante do dito. Isso não pode ser traduzido aqui. Mas o que se torna cada dia mais claro é a necessidade da presença do outro para a escavação ser feita, da escuta do que está fora, que pode me libertar para escavar, pois sei que tenho alguém que cuida de mim no escuro em que adentrarei.

Depois que o ator escava um pequeno trecho escolhido por ele, passamos a experienciar as escavações do texto que será posto em cena. 


\section{vestígios do ator cuidador da escuta e do dizer do outro}

O ator, ao começar a dizer um texto (lido ou já memorizado a partir dessa sutil escuta, nosso tema), nos lugares referidos ao longo desta escrita, muitas vezes precisa de uma grande aproximação física de quem guia o trabalho. Esta solicitação está muito além dos crescimentos visíveis do trabalho do ator quando ele se alterna entre estar dentro e fora de cena, nos lugares de ator e público, em tudo que conquistamos quando aprendemos-vendo e aprendemos-fazendo, ao permitirmos o diálogo entre ser-ator e ser-platéia em nossos próprios corpos. Disse 'muito além' pois não se trata disso. Tratase aqui de o ator ser ele também um guia do seu parceiro, ser um cuidador para que, nos campos sutis de passagem entre uma experiência com o corpo, antes da chegada do texto, seja acolhida a proximidade do dizer sem que o ator se perca em seus lugares mais conhecidos, naquilo que o corpo naturalmente já experiencia com mais frequência no dia a dia. O cuidador é um guardador da proximidade, alguém que ali - e todos ficam neste lugar - também cuida de si, ao ter como rigor o manter-se próximo do outro. Aproximando-se do outro, aproxima-se de si. Esta é a espera aqui. Para isso, levo aos atores as etimologias acima transcritas, conversamos sobre esse lugar antes e depois de as experiências começarem.

Trata-se de um zelo.

O ator diante da palavra. Com a possibilidade de aproximar-se e trazer o vigor do que não estava dado a ver antes de seu dizer tornado público: o ator que convoca. Evoca para o próximo de si, para a presença. Evoca (chama) uma presença a partir do seu dizer auscultador. Quando diz, o ator provoca o que vive no que diz (se é que a palavra vive ali!) e invoca a ausência do que está compreendido/incompreendido/pendido no dito. Mas ator e palavra não são o mesmo, um mesmo. Não é isso que se quer aqui. 
Por isso gosto do ator nesse cuidar que é coro para a insistência de uma escuta que preserva o entre, os espaços, sem, com isso, perder a proximidade.

O meio dos dois é a intimidade. 'Entre' é o nome que nossa língua dá ao meio de dois. A língua latina diz inter. Inter corresponde ao alemão unter. A intimidade de mundo e coisa não é mistura. A intimidade prevalece somente onde o íntimo, mundo e coisa, puramente se distingue e permanece distinto. No meio de dois, entre mundo e coisa, em seu inter, nesse unter, prevalece o corte (Schied) que os separa e diferencia ${ }^{56}$. (HEIDEGGER, 1995, p.53)

O espaço permanece, dura. E precisa ser escutado pelo ator. Desde o início do encontro com o texto. Encontrar intimidade no escutar-e-dizer a palavra não suspende o espaço 'entre', e é nele que insistimos: no 'entre’. Pelo corte, a diferença perdura e, assim, podemos correr menos o risco de perdermo-nos do presente. Quem sabe, talvez, possamos fazer menos esforço.

Delinearei um exemplo de ação na direção desse lugar cuidador experienciado pelo ator. As impressões são de cada um; aqui descreverei apenas ações já presenciadas. Após percorrer a primeira caminhada apontada na página 100 , o ator $(A)^{57}$ recebe o texto que será lido. Um ator (B), que não percorreu a caminhada, mas testemunhava toda a experiência de 'fora', dá esse texto ao ator A pouco depois que este pára. $\mathrm{O}$ ator B mantém-se próximo, perto do corpo do ator A, com a orientação de procurar, ali, durante toda a leitura de A, cuidar para que ele, em sua leitura e dizer, não se afaste de si, não retorne bruscamente ao estado anterior à caminhada, e perceba sua trajetória de ler e dizer nascida nesse estado evocado pela caminhada. Ao orientá-los, busco deixar claro que o que cada um (no lugar B) fará, para chamar o outro a si e cuidar para guardar alguma proximidade do outro a ele mesmo, é absolutamente originado em seus impulsos ‘cuidadores’ do momento, sem regras, sem normas. Presencio e executo ações

\footnotetext{
${ }^{56}$ unter (sob, debaixo de, por baixo de); Schied (passado imperfeito do verbo scheiden, separar, partir, despedir-se); Unterschied (diferença), conforme Langenscheidts, 1982.

${ }^{57}$ Nunca usei essas letras para nomear ninguém. Elas servem aqui para facilitar a posição dos atores.
} 
as mais variadas nesse lugar cuidador: tocar partes do corpo do outro (com as mãos, com as costas, com os pés), sussurrar ou falar em voz alta (ou bem alta) orientações e pedidos para o outro ('fale deitando no chão', 'fale diretamente para outra pessoa da sala', 'perceba a palavra saindo como um nascimento de sua boca, as bordas que ela atravessa'). São exemplos.

O norte principal aqui é cuidar, com suas impressões, para que o outro não se distancie de si, que inicie seu dizer a partir de algum recolhimento. Esta percepção pode conter muitos distanciamentos, ela não se quer certa, guia para uma forma específica. Busca abrir espaço para o ator experienciar o lugar cuidador e, com isso, despertar alguma possibilidade de ele mesmo cuidar de si, de sua presença, de sua própria escuta, de recolher a palavra ao doá-la. E contém, claro, todo o imponderável de uma improvisação ao ser, ele mesmo, no gesto cuidador, levado a buscar alguma interioridade durante sua relação com o outro. Ao aproximar-se do dentro do outro, com alguma delicadeza em sua própria trajetória para escutá-lo, ele mesmo escuta-se nela, sem esforço, quase sem notar. Cuida de si quase sem nenhum querer para si, ao cuidar do outro nalguma intimidade solicitada pela proximidade. Pode, ao experimentar-se como ninho para o outro, aprender o ninho para si. Ao fazê-lo, o outro se acalma, sabe que tem alguém ali para que ele possa percorrer seu caminho sem tanto esforço para ocupar-se de si. Os dois lugares (A e B) são adensados na experiência. Retornos a esse lugar cuidador devem acontecer muitas vezes, para que, com as revisitações, um lugar (cuidar e ser cuidado) doe ao outro a consciência serena da escuta aberta neste recolhimento. Um repouso para si (o que está dentro) nascido justamente de um repouso do outro (aquele que cuida), para que este ator possa sempre cuidar da palavra com simplicidade.

"O ninho, como toda imagem de repouso de tranqüilidade, associa-se imediatamente à imagem da casa simples." (BACHELARD, 2005. p. 110) 
"Assim, contemplando o ninho, estamos na origem de uma confiança no mundo, recebemos um aceno de confiança, um apelo à confiança cósmica. 0 pássaro construiria seu ninho se não tivesse seu instinto de confiança no mundo? Se escutarmos esse apelo, se fizermos desse abrigo percário que é o ninho paradoxalmente, sem dúvida, mas sob o próprio impulso da imaginação - um refúgio absoluto, voltaremos às fontes da casa onírica. Nossa casa, captada em seu poder de onirismo, é um ninho no mundo. Nela viveremos com uma confiança nativa se de fato participarmos, em nossos sonhos, da segurança da primeira morada. Para vivermos essa confiança tão profundamente integrada em nosso sono, não temos necessidade de enumerar razões materiais de confiança. Tanto o ninho como a casa onírica e tanto a casa onírica como o ninho - se é que estamos na origem de nossos sonhos - não conhecem a hostilidade do mundo. A vida começa para o homem com um sono tranquiilo e todos os ovos do ninho são bem chocados. A experiência da hostilidade do mundo - e consequientemente nossos sonhos de defesa e de agressividade - são posteriores. Em seu germe, toda vida é bem-estar. 0 ser começa pelo bem-estar." (BACHELARD, 2005, p. 115) 


\section{vestígios de algum repouso, de alguma deriva}

Começo frequentemente essa prática com a leitura do trecho que se segue para

os atores. Sem explicitar a origem do texto ou o tema do trabalho, abro as páginas de

meu livro velho e leio, em voz alta:

- Lá eles tinham um curso obrigatório. Expressão Oral. Nisso fui reprovado.(...)

- É um curso em que cada aluno tem que levantar na aula e fazer um discurso. Sabe como é. Com espontaneidade e tudo. E, se o sujeito sai um pouquinho do assunto, todo mundo tem que gritar: "Digressão!" o mais depressa possível. 0 negócio me deixava meio maluco. Tirei uma nota horrível.

- Por quê?

- Ah, sei lá. Aquela história de digressão me chateava. Sei lá. O problema comigo é que eu gosto quando um sujeito sai do assunto. É mais interessante e tudo.

- Você não gosta que uma pessoa seja objetiva quando conta uma história?

- Claro! Gosto que a pessoa seja objetiva e tudo. Mas não gosto que seja objetiva demais. Não sei. Acho que não gosto quando uma pessoa é objetiva o tempo todo. Os garotos que conseguiam as melhores notas em Expressão Oral eram objetivos o tempo todo, isso eram. Mas tinha um garoto, o Richard Kinsella. Ele não era muito objetivo e a turma vivia gritando "Digressão!" quando ele falava. Era horrível. Primeiro porque ele era um cara muito nervoso. Isso mesmo, nervosíssimo - e, quando chegava a hora de falar, os lábios dele começavam a tremer e, do fundo da sala, a gente mal conseguia ouvir o que ele estava dizendo. Mas, quando os lábios dele paravam um pouco de tremer, eu gostava dos discursos dele mais do que os de qualquer outro sujeito. Ele também quase foi reprovado. Passou raspando, porque a turma vivia gritando "Digressão!" para ele. Por exemplo, ele fez um discurso sobre uma fazenda que o pai dele tinha comprado em Vermont. 0 tempo inteirinho que ele falou a turma ficou gritando "Digressão!" e o professor, um tal de Vinson, deu-lhe uma nota ruim pra diabo porque ele não contou que espécies de animais e legumes e outros troços tinha lá na fazenda e tudo. Sabe o quê que ele fazia? Começava contando essas coisas todas e aí, de repente, começava a falar de uma carta que a mãe dele tinha recebido do tio, e que o tio teve poliomielite e tudo aos quarenta e dois anos de idade, e se recusava a receber visitas no hospital porque não queria que ninguém o visse com a perna na tipóia. Não tinha muita ligação com a fazenda, concordo, mas era simpático. É um troço simpático quando alguém fala de um tio. Principalmente quando começa a falar da fazenda do pai e de repente, fica mais interessado no tio. 0 negócio é que eu acho uma sujeira começarem a gritar "Digressão!" pra um sujeito quando ele está todo embalado num assunto... Não sei. É difícil de explicar.

Eu nem estava com muita vontade de tentar. (...)

- Holden... Uma perguntinha pedagógica e um pouquinho batida. Você não acha que há um tempo e um lugar para tudo na vida? Você não acha que, 
se alguém começa a falar sobre a fazenda do pai, deve agüentar a mão e, depois, arranjar um jeito de falar sobre a tipóia do tio? Ou, então, se a tipóia do tio é um assunto tão fascinante, ele não devia tê-lo escolhido logo como tema da exposição, em vez da fazenda? (...)

- Acho...Sei lá. Acho que sim. Quer dizer, acho que devia ter escolhido o tio como tema, em vez da fazenda, se isso era mais interessante para ele. Mas o caso é que, muitas vezes, a gente só descobre o que interessa mais na hora que começa a falar sobre uma coisa que não interessa muito. Quer dizer, às vezes a gente não consegue evitar isso. O que eu acho é que a gente deve deixar em paz uma pessoa que começa a contar uma história, se a história é pelo menos interessante e o sujeito se anima todo com o assunto. Gosto de ver uma pessoa ficar toda animada com um assunto. É bonito. 0 senhor não conhece esse professor, o tal do Vinson. Ele às vezes deixava a gente maluco, ele e a droga da turma. Vivia dizendo à gente para unificar e simplificar. Há coisas que a gente simplesmente não pode fazer assim. 0 negócio é que a gente quase nunca consegue simplificar e unificar um troço, só porque alguém mandou. (...) (SALINGER, 1965. p. 165)

Fecho esse primeiro livro e, em seguida, abro um outro livro e leio:

0 que eu gostaria de renovar, cada um dos anos em que me será dado aqui ensinar, é a maneira de apresentar a aula ou o seminário, em suma, de 'manter' um discurso sem o impor. (...) E eu me persuado cada vez mais, quer ao escrever, quer ao ensinar, que a operação fundamental desse método de desprendimento é, ao escrever, a fragmentação, e ao expor, a digressão ou, para dizê-lo por uma palavra preciosamente ambígua: a excursão. Gostaria pois que a fala e a escuta que aqui se trançarão fossem semelhantes às idas e vindas de uma criança que brinca em torno da mãe, dela se afasta e depois volta, para trazer-lhe uma pedrinha, um fiozinho de lã, desenhando assim ao redor de um centro calmo toda uma área de jogo, no interior da qual a pedrinha ou a lã importam finalmente menos do que o dom cheio de zelo que deles se faz. Quando a criança age assim, não faz mais do que desenrolar as idas e vindas de um desejo, que ela apresenta e representa sem fim. (BARTHES, s/d, p. 43)

Há um texto para ser lido ou dito, um texto para ser posto em cena. Depois de escutarem os dois trechos acima, a partir dos quais pretendo estabelecer um diálogo entre 'digressão' e 'excursão' para iniciarmos um repouso sobre o texto de trabalho daquele grupo, oriento os atores ao que se segue. Todos lerão o texto (foco do trabalho daquele núcleo de pessoas) aceitando todas as excursões a que ele levar, as digressões, as derivações. Ao ler, por exemplo, posso ser levada por aquilo que me ocorre dizer sobre o texto (já pensado antes ou pensado agora), ou pelo que o texto me diz e quero dizer em voz alta, ou pelo que se oferece no encontro, ou ainda por... muitas outras 
coisas que ainda não se mostraram. Ao ler e dizer o texto em si, tenho os olhos abertos, escuto os parceiros e leio. Ao excursionar ou derivar, fecho os olhos e digo, digo, digo, escutando-me. Os parceiros escutam-me, tendo seus olhos abertos. E assim também farei ao escutá-los em suas derivas. Retomamos a leitura do texto ao final de cada digressão. Quem excursiona é quem diz o momento de retornar, reencontrando o papel à sua frente.

Para começar, trouxe Salinger e Barthes.

Aqui, o ator re-escreve o lido, enquanto deriva em seu pensar, perdendo-se no que lê. Cuidamos, somente, para que possamos, todos, perceber o momento de retornar e repousar novamente nas palavras do texto.

“Todo sonhador solitário sabe que ouve de outra maneira quando fecha os olhos. Para refletir, para escutar a voz interior, para escrever a frase central, condensada, que diz o ‘fundo' do pensamento, quem nunca apertou fortemente as pálpebras com os dedos? Então o ouvido sabe que os olhos estão fechados, sabe que a responsabilidade do ser que pensa, que escreve, está nele. Poderá relaxar quando a pessoa reabrir os olhos."

(BACHELARD, 2005, p.186)

“Se incluí a Visibilidade em minha lista de valores a preservar foi para advertir que estamos correndo o perigo de perder uma faculdade humana fundamental, a capacidade de pôr em foco visões de olhos fechados, de fazer brotar cores e formas de um alinhamento de caracteres alfabéticos negros sobre uma página em branco, de pensar por imagens". Penso numa possível pedagogia da imaginação, que nos habitue a controlar a própria visão interior sem sufocá-la e sem, por outro lado, deixá-la cair num confuso e passageiro fantasiar, mas permitindo que as imagens se expressem numa forma bem definida, memorável, autosuficiente, ‘icástica'." (CALVINO, 1990, p. 108.) 


\section{vestígios da relação boca-orelha da narração}

Para insistir em outro modo de aproximação dos textos que nos abra para um dizer escutante, outra ocupação nossa tem sido pensar algo que chamamos o estado do narrador. Trata-se de lembrarmo-nos e experienciarmo-nos como narradores e, ao mesmo tempo, lembrarmo-nos dos narradores e das narrativas que nos aconteceram (e acontecem) como acontecimentos apropriadores ${ }^{58}$. Para isso, recorremos ao célebre texto "O narrador", de Walter Benjamin. Em 1936, em texto que trata da obra de Nikolai Leskov, Benjamin lamenta, nostalgicamente, o desaparecimento do narrador, em função do baixo valor da experiência: "As ações da experiência estão em baixa (...), como se estivéssemos privados de uma faculdade que nos parecia segura e inalienável: a faculdade de intercambiar experiências." As condições de realização da transmissão de uma experiência em sentido pleno não existem mais, afirma Benjamin. E prossegue: não há mais comunidade, as gerações estão distantes, não há mais interesse pelo velho, nem pelas histórias que ele contava; não se tem mais tempo nem espaço para o gesto de contar, pois o trabalho industrial pede pressa, rapidez. Mas a mais desoladora das razões para o desaparecimento do narrador está no silêncio com que os combatentes "tinham voltado do campo de batalha" após uma das "mais terríveis experiências da história”, a I Guerra Mundial: "Mais pobres em experiências comunicáveis, e não mais ricos." Finda o desejo de narrar o vivido. Por que a "experiência que passa de pessoa a pessoa é a fonte a que recorreram todos os narradores". Não mais se quer transmitir nada a ninguém e, por isso, "são cada vez mais raras as pessoas que sabem narrar devidamente".

Benjamin leva-me a pensar sobre tempo e espaço. Os dois representantes arcaicos da narração que desapareceram são o camponês sedentário e o marinheiro comerciante. "Na realidade, esses dois estilos de vida produziram de certo modo suas respectivas

58 “O acontecimento apropriador é o mais imperceptível no imperceptível, o mais simples no simples, o mais próximo no próximo, o mais distante no distante, onde nós, mortais, sustentamos nossas vidas.” (HEIDEGGER, 2003, p. 207) 
famílias de narradores." O sedentário traz-nos a distância temporal, as histórias que são contadas de pai para filho, de avô para neto. 0 marinheiro oferece-nos suas histórias a partir da narração do que ele viveu em terras distantes, em espaços que desconhecemos. Junto dos tipos arcaicos, Benjamin ainda nos lembra que narrar é também aconselhar: "O senso prático é uma das características de muitos narradores natos." E aconselhar não é dar respostas, informar, explicar.

Aconselhar é menos responder a uma pergunta que fazer uma sugestão sobre a continuação de uma história que está sendo narrada. Para obter essa sugestão, é necessário primeiro saber narrar a história (sem contar que um homem só é receptivo a um conselho na medida em que verbaliza a sua situação). 0 conselho tecido na substância viva da existência tem um nome: sabedoria.

Ao subir nos ombros de Benjamin para parafraseá-lo, o filósofo Fernando Savater evoca: "A narração, para ocorrer, exige uma comunidade" (SAVATER, 2001, p. 33). 0 conselho, a narração de uma experiência e a narrativa lida, todos exigem o outro como elemento fundador de sua origem.

Por duas razões fundamentais a verdadeira narração é sempre ambígua: porque nenhuma lei necessária esgota a inexplicável concreção de seus perfis e porque ela só se completa efetivamente na intimidade do ouvinte que a aceita, tal como a metade do anel e o fragmento do mapa só ganham sentido na presença de quem trouxer a parte que lhes falta. (SAVATER, 2001, p. 32)

"Boca-orelha", dizem os griots, uma só existe pela existência da outra, uma é absolutamente necessária à outra.

Porém, diz Benjamin, esse encontro entre narrador e ouvinte não é mediado de explicações.

Metade da arte narrativa está em evitar explicações. (...) 0 extraordinário e o miraculoso são narrados com a maior exatidão, mas o 
contexto psicológico da ação não é imposto ao leitor. Ele é livre para interpretar a história como quiser, e com isso o episódio narrado atinge uma amplitude que não existe na informação. (BENJAMIN, 1976, p. 203.)

$\mathrm{Na}$ relação boca-orelha da narração, apontada pelo célebre texto que nos visita aqui, mesmo quando esta relação se dá pela palavra escrita - mantemos a nomenclatura do corpo em presença, pois é disso também que o texto trata, da presença do narrador a que a narração remete quando lida -, tem-se ainda, sempre, a presença do repetível daquilo que se escuta: uma história é contada para ser recontada, ouvida para ser recontada, repetida. Nos movimentos de contar e recontar, o que assegura à memória a retenção suave dos relatos e assegura sua repetição é um processo de assimilação que se dá

em camadas muito profundas e exige um estado de distensão que se torna cada vez mais raro. Se o sono é o ponto mais alto da distensão física, o tédio é o ponto mais alto da distensão psíquica. 0 tédio é o pássaro de sonho que choca os ovos da experiência. 0 menor sussurro das folhagens o assusta. Seus ninhos - as atividades intimamente associadas ao tédio já se extinguiram na cidade e estão em vias de extinção no campo. Com isso, desaparece o dom de ouvir, e desaparece a comunidade dos ouvintes. Contar histórias sempre foi a arte de contá-las de novo, e ela se perde quando as histórias não são mais conservadas. Ela se perde porque ninguém mais fia e tece enquanto ouve a história. Quando mais o ouvinte se esquece de si mesmo, mais profundamente se grava nele o que é ouvido. Quando o ritmo do trabalho se apodera dele, ele escuta as histórias de tal maneira que adquire espontaneamente o dom de narrálas. Assim se teceu a rede em que está guardado o dom narrativo. E assim essa rede se desfaz hoje por todos os lados, depois de ter sido tecida, há milênios, em torno das mais antigas formas de trabalho manual. (BENJAMIN, 1976, p. 204)

O autor ainda recorre à descrição de Paul Valéry da imagem espiritual do mundo dos artesãos, do qual

provém o narrador: (...) Iluminuras, marfins profundamente entalhados; pedras duras, perfeitamente polidas e claramente gravadas; lacas e pinturas obtidas pela superposição de uma quantidade de camadas finas e translúcidas... - todas essas produções de uma indústria tenaz e virtuosa cessaram, e já passou o tempo em que o tempo não contava. 0 homem de hoje não cultiva o que não pode ser abreviado. (...) dir-se-ia que o 
Poderíamos prosseguir entrando no tema da morte como fonte para a narrativa, o caráter público dela na sociedade e outros assuntos abertos pelo texto de Benjamin. Valemo-nos de copiar pedaços aqui somente para pensar as relações entre o que vimos dizendo aqui e a abertura para um estado de narrador que pode, também, vir a aproximar o ator da palavra que lê e diz.

"O narrador" costuma ser lido nos espaços onde experienciamos nossas práticas, pois a experiência de permanecer ali, percorrer os temas ali, é sempre melhor do que qualquer convite que algumas citações possam fazer.

As perguntas que o texto tem provocado e as práticas delas nascidas estão em presença constante com meu encontro com a tradição griot. Diálogo inevitável.

\author{
"O ferreiro forja a Palavra, \\ 0 tecelão a tece, \\ O sapateiro a amacia, curtindo-a." ${ }^{59}$
}

As palavras do texto $A$ tradição viva, do etnólogo fula Amadou Hampâté Bâ, do Mali, contam ainda que os gestos de cada um desses ofícios "reproduzem o mistério da criação primeira". Por exemplo, o vaivém dos pés, que sobem e descem para acionar os pedais no trabalho do tecelão, "lembra o ritmo original da Palavra criadora. (...) A tira do tecido que se acumula e se enrola em um bastão que repousa sobre o ventre do tecelão representa o passado, enquanto o rolo do fio a ser tecido simboliza o mistério do amanhã, o desconhecido devir." (BÂ, s/d, p. 197)

${ }^{59} \mathrm{BÂA}, \mathrm{s} / \mathrm{d}$, p. 196. 
A distância dos ofícios tradicionais, a distância da natureza desse ator com o qual trabalhamos, e sobre o qual tratamos nessa escrita, levam-nos, então, a buscar práticas que permitam algum contato com o que acena, para nós, o texto de Benjamin e todas as derivações aí surgidas. Perguntamo-nos: quais os exercícios de ativação da reminiscência? Que práticas podem nos devolver algum prolongamento na relação com o tempo, sem que cultivemos a necessidade (que se impõe) de abreviá-lo? Como percorrer o caminho que nos alcança (a palavra experiência trazida por Heidegger anteriormente aqui) a partir de alguma derrubada de nossas necessidades de 'informação', de ‘explicação', de ‘comunicação'?

As práticas nascidas desse vasto campo aqui delineado tratam de abrir também uma aproximação entre ator e texto, mas a partir, agora, de um trabalho que não repousa diretamente sobre as palavras do texto. Podemos dizer que se trata de um repouso indireto, ainda no campo da intimidade. São elas:

Lembrar-se de si. Este é um laboratório aprendido com Antonio Januzelli que vem junto com seu dizer: 'fazer o caminho de volta para não se perder'. Sotigui Kouyaté diz, em todos os seus estágios: 'se eu não sei pra onde vou, mas sei de onde eu vim, eu não me perco.' Eles não se conhecem. A prática consiste em pedir que o ator se sente, de frente para todos os outros daquele grupo de trabalho, e conte-se, narre-se. Lembre-se de si, porém publicamente, em exposição. Com alunos iniciantes, costumo oferecer alguns 'nortes' para este narrar: falar de sua origem, do que o atrai e o que repudia, e contar três ou quatro acontecimentos marcantes. Os temas para o traço de cada um ali podem variar infinitamente. 
Lembrar-se dos narradores e das narrativas marcantes em sua vida. Percebemos que o ator se esquece de que é também um narrador, e é público que testemunha narrativas e narradores pela sua vida afora. Queremos lembrá-lo de lembrar-se disso. De modo análogo a essa prática, escrevi todo o primeiro capítulo do presente texto. Meu norte, ali, porém, era a rememoração das minhas experiências com a palavra que me pungiu. A seguir, copio a rememoração da atriz Maria, por escrito, feita em 1 de novembro de 2006.

\section{“Narradores e Narrativas, Maria. \\ 1. Infância}

a. A professora de Português lia um capitulo por dia, no final da aula, de um livro em francês que ela traduzia na hora. Era Os desastres da Sofia, da Condessa de Ségur.

b. Minha mãe leu para nós, a cada noite, um dos livros da minha vida: O sofá estampado. 'Cavando fundo, sumindo e sumindo, e morrendo a paz e a vó do Vitor.'

c. Grandes livros mágicos que eu ganhei do meu tio: Mitologia Grega. Um sem fim de histórias secretas e fantásticas que eu lia só. Meu primeiro prazer solitário. 'Geia, Cosmos, Cronos, Zeus. E a virgem Ceres/Diana cavalgando pelas matas. Eu queria ser amazona!'

d. A Tia Nastácia contando a história do monstro Papamel. 'Que lindo! Uma história pode entrar na outra!' As histórias são feitas de camadas. 'Dentro do monstro tem uma pedra e dentro da pedra um ovo, e dentro do ovo uma chave e um cofre, a chave abre o cofre que guarda uma vela. A chama da vela é a vida do monstro.'

e. Quando eu e minha irmã ficávamos doentes, minha mãe tinha de fazer nossas vontades. Então ela fazia o que odiava: ler para nós histórias em quadrinhos! Mas não qualquer uma. Ela lia Tintim para nós! Era o máximo. Ela fazia todas as vozes e nós víamos os desenhos!! 'Rastapoulos, Haddock, Girassol, e um mundo de informações: Aeroporto de Jacarta, Leste Europeu, Índia e Arábia!!!’

\section{Os grandes livros da minha vida:}

a. O idiota, de Dostoievski. A narrativa no momento anterior ao ataque de Mickim, quando ele tem um momento luminoso de lucidez e entende a razão de tudo: 'Rogójin, Rogójin!'

b. A montanha mágica, de Thomas Mann. Quando Castorp vê o céu e se alegra, quando vê o interior de Joachin, quando se perde na neve.

c. No Grande Sertão, quando a narrativa se torna endiabrada e rodopia.

d. Ai! A morte da Baleia, em Vidas secas, de Graciliano Ramos.

\section{Filmes}

a. Quando Antoine Doinel rodopia na centrífuga do parque de diversões em Os Incompreendidos, de Truffaut . E quando ele chega na praia.

b. 0 casamento e o envenenamento em Feios, sujos e malvados (Scola). Aquela orgia de bolonhesa e formicida. 


\section{Narradores}

a. A minha amiga Cris quando descreve imagens caricaturáveis: 'Fulana fumava a $90^{\circ}$ '

b. Com ela, a minha amiga Rose, que faz parte do mesmo time: 'Os professores sendo atravessados pelos conteúdos transversais"

c. O Chiquinho Medeiros: "Minha mãe ouvia no rádio as notícias da ditadura e ia perdendo os pontos do tricô. Aquele cachecol ia crescendo infinitamente sem que ela percebesse'.

d. Minha avó quando conta histórias de pessoas distantes.

\section{No palco}

a. A Denise Stoklos é uma grande contadora de histórias.

b. O livro de história natural, coreografia de Philippe Decouflé.

c. O Habib Dembélé (Peter Brook), evidente - inesquecível.

d. A calma de César Brie (Teatro de los Andes) contando a história de Marcelo Quiroga.

\section{No fone de ouvido}

a. O Jackson do Pandeiro, o Adoniran Barbosa, o Noel e sempre o Chico.

\section{Não pára aqui}

8. Eu

Existe sempre uma sabedoria. Ou a acessamos através das fábulas, ou testemunhamos aqueles que se perdem no percurso. Ou somos privilegiados de tocar este conhecimento ou reconhecemos nossa falência ao estar marginal a ele. Relampejos de completude nos assomam. A hermenêutica de Hans Castorp é a tradução: Haverá sentido neste mundo se já não nos ecoam Dianas e Zeus? Deus está morto... graças a Deus! A narrativa dos perdedores...

Lá vai Castorp, fruto doentio da vida, rumo ao campo de batalha. Só leva a meia e os sapatos, para atravessar o oceano e chegar ao país das mangas. Corre pra onde? 0 mar é o fim ou o começo, Antoine? Vomita à beira d'água o formicida. E avante no comando das tropas, o sertão para trás. Avante, cavando em si o tecido florido... Amarelo bem clarinho salpicado de flor, vez ou outra um jasmim, uma violeta..."

Seguem-se outras práticas, ainda na relação boca-orelha.

Praticar a narração oral de histórias, a partir das três modalidades fundamentais (que me foram assim nomeadas pelos griot, ator e diretor Hassane Kouyaté): história desconhecida do público e conhecida do narrador - aqui normalmente as histórias pessoais são as mais frequentes, relatos de experiências; história conhecida de todos, narrador e público - 
aqui proponho textos que checamos como sendo conhecidos de todos, ou histórias infantis, populares; e história desconhecida de todos - aqui trabalhamos com improvisações a partir de diversas modalidades. Dedicome, nas histórias conhecidas de todos - uma das modalidades mais difíceis para o narrador, pois o que se sobressai é um 'como', já que todos conhecem o desenrolar da história -, a estudar o assunto do 'ponto de vista' junto com os atores. Para isso, proponho que as histórias sejam narradas com múltiplas alterações de pontos de vista: por exemplo, quem conta $O$ chapeuzinho vermelho é uma árvore da floresta, ou são os sapatos da menina, ou é a cesta de doces, ou é a avó. Isso obriga o ator a aproximar-se do texto (futuramente) em espaços surpreendentes de sentido para ele mesmo, pois precisa realmente adentrar na história e ver, dali, daquele lugar, o que aquele novo narrador vê da história. A avó da Chapeuzinho não é o narrador onisciente que domina toda a fábula; ela só pode contar uma parte do que o ator já conhece de antemão, a parte que ela testemunha ali dentro. Ele é obrigado a pensar-se em outro ponto de vista para olhar para a história. Um dos alunos do curso de Interpretação 3 e 4 que coordenei na ECA-USP em 2008 escolheu contar a história do texto Hamlet, de William Shakespeare, do ponto de vista do lago de Elsinore.

O ator deve, em solo ou em grupo, contar para o espectador todo o 'osso' (é esta a palavra que uso) do texto que será encenado, do texto do qual se aproxima para estudo ou montagem. Para isso, fazemos improvisações livres desse contar; escrevemos as histórias antes, para termos esse 'osso' na cabeça, as linhas, a espinha do texto; recorremos a jogos simples em que os atores são postos lado a lado e, para contar a história, cada um 
deve dizer somente uma frase; ou, também lado a lado, devem contar a história em versos rimados e de idênticas sílabas.

O que se acena aqui é a possibilidade de cuidar da palavra em um campo aberto, pela localização precisa desse lugar de narrador em nossos corpos. Essa localização acontece pela lembrança do assunto em nós, por meio de exercícios bastante simples de rememoração escrita, falada, e também pela experimentação das práticas apontadas nas quais somos os próprios narradores.

Aqui todos os lugares podem dialogar. Aprender o quieto é aprender a durar (na chance de chocar ovos de alguma experiência), perdurar. Aprender a duração é aprender-se no percorrer de um caminho, mirar-se enquanto andante (pela calma que ela oferece) e escutante da própria caminhada. Os dois pássaros se encontram, bicando e mirando.

Repousar no todo (a aplicação do studium) e receber o detalhe (a flechada do punctum). Derivar, aqui, é estar presente na presença, aceitando tudo o que em nós olha para trás e, ao mesmo tempo, também para o que virá, a partir da folha em nossas mãos (texto/história), e para o que lemos e dizemos a partir daqui, dali. Boca e orelha (do ator que narra) e boca e orelha (do ator que ouve) a serviço de uma escuta de bicho. O homem presente, em contato com as sutilezas, com os espaços entre as coisas, os outros. Escutando-se por escutar o outro, aproximando-se de si por aproximar-se do outro (da história que conta, do fato que lembra, do osso do texto que será encenado). Ele cuida do todo porque mora na miniatura, com acuidade. Recebe a picada por 
reconhecer o cenário, e talvez re-conhecer-se no cenário. E, como nas caminhadas relatadas, conecta morte e vida, ao narrar (ou narrar-se) sempre em tempo presente.

Olho que olha a palavra inscrita no texto, presença quieta que oferece receptividade, mão que cuida do caminho ao dizer. Benjamin pede para retornar:

A alma, o olho e a mão estão assim inscritos no mesmo campo. Interagindo, eles definem uma prática. (...) Na verdadeira narração, a mão intervém decisivamente com seus gestos, aprendidos na experiência do trabalho, que sustentam de cem maneiras o fluxo do que é dito. (...) Podemos ir mais longe e perguntar se a relação entre o narrador e sua matéria - a vida humana - não seria ela própria uma relação artesanal. Não seria sua tarefa trabalhar a matéria-prima da experiência - a sua e a dos outros - transformando-a num produto sólido, útil e único? (BENJAMIN, 1976, p. 220) 
A dedicação prática ao tema do dizer escutante da palavra lida, a ação acontecida na tradução escrita da prática, a experiência de cuidar do que transmito, as alianças práticas e teóricas que me aconteceram, tudo tem afetado também minha maneira de apreciar o trabalho dos atores, de devolver o que percebo a eles, considerando também as devoluções entre eles, nos núcleos com os quais trabalho. 0 aconselhamento como função prática do narrador, apontada por Walter Benjamin, e em minha convivência há sete anos com Sotigui Kouyaté, além de experiências pessoais nãonomeáveis nesta escrita, geraram a prática que descrevo abaixo.

Presentes-cuidadores em forma de narrativa de ficção: após as experiências dos atores como narradores, ou após algum tempo de trabalho de um mesmo núcleo de pessoas em experiências diversas, proponho que, ao invés de comentarmos uns os trabalhos dos outros, cada um escreva para todos os outros (sendo que cada um escreve também para si) uma narrativa que configure um presente que ele queira dar ao outro. 0 presente deve ser escrito na direção de cuidar do que acha que o outro precisa para seu trabalho. Porém, esse texto é uma ficção, pode ser um presente totalmente inventado e 'impossível' de ser adquirido. Esse texto, geralmente, é escrito fora do espaço de trabalho e trazido por escrito para ser lido publicamente entre todos. No dia em que cada um traz suas narrativas-cuidadoras destinadas a si e a todos os parceiros de trabalho, solicito ainda que criem um 'doador' de cada presente, um ‘quem' que deverá ser o presenteador, mas que só é nomeado depois que o presente já está configurado em narrativa no 
papel. Os presentes são doados, em geral, quando o corpo já está aquecido e todos já estamos em trabalho há algum tempo. Antes que comecemos as doações, todas públicas, oriento-os ainda, a partir de pensamentos já explicitados nesta escrita anteriormente, para que não tentemos encaixar o que escutaremos no lugar de um 'querer-dizer', ou seja, que não interpretemos psicologizando o escutado, que não intelectualizemos as imagens dali derivadas. A busca é por algum silêncio na recepção. Transcrevo a seguir alguns presentes-cuidadores surgidos em espaços de práticas, já com o ‘quem' inserido, pelos atores, em suas narrativas. São textos de atores do grupo Jogando no Quintal, de São Paulo, e dos núcleos de práticas que realizei em diálogo com esta escrita.

\footnotetext{
"Eu sou o maior marceneiro da floresta e te dou uma caixa cheia de coisas para serem começadas com seu impulsos. Mas, saiba que, sempre que você começar, logo imediatamente um grupo de pessoas chegará para continuar o que começou e elas que terminarão tudo, felizes e se divertindo muito. Você inicia, e fica olhando para elas. Só depois disso é que troca de 'objeto'. Eles são:

- um parafuso, com a chave de fenda ao lado, um buraco com a porca.

- $\quad$ um relógio parado para dar corda e fazê-lo funcionar.

- uma caixinha de música para dar corda e fazer a bailarina dançar.

- uma pá para começar a jogar terra num morto.

- um par de luvas cirúrgicas para começar a puxar um bebê nascendo.

NESTA ORDEM!"
}

"Eu sou seu mestre no teatro e te dou um grupo de amigos (tipo banda) bem diferentes uns dos outros, mas todos bem amigos, unidos (você é um deles), pulando amarelinha na praça e rindo, tomando groselha ou um outro 'refresco', e juntos, você dentro, muito dentro de tudo, do grupo, do suco, da amarelinha."

"Eu sou a mulher dos mil bichos e te dou um cesto com três filhotes de gato, de cores diferentes. Nenhum deles vai sobreviver se permanecer contigo. Eles têm que ser entregues a outras pessoas, mas é preciso acompanhar seu desenvolvimento à distância, ou eles sofrerão." 
"Sou um andarilho indiano e te dou de presente uma vaca mascando vagarosamente um punhado de capim, para que, enquanto vocês estiverem na trilha que conduz à casa onde haverá a novena, ela, a vaca, possa observá-los enquanto passam pela trilha."

"Eu sou o vento suave e te dou um ano de experiência cotidiana (12h/dia) com o maior manipulador de bonecos e formas animadas do Japão. Você vai voltar e ser a principal formadora de manipuladores de formas animadas do Brasil nos próximos 30 anos. E o salário, aqui, é de 16.000 reais por mês, com férias e $13^{\circ}$. Lá, nada."

"Sou uma dona de pensão, em qualquer lugar perdido no interior do Brasil. Sou velha, feia e desdentada. Trepei muito na vida, bebi todas, e agora sou uma mulher vivida, acabada, decadente e cheia de histórias pra contar. Te dou uma cachaça! Da mais barata!"

\begin{abstract}
"Sou um jogador de basquete, bem parecido com o Michael Jordan, enorme, bonito. Venho carregando uma coisa pesada e grande que você sabe que é pra você. Quando chegamos perto, me transformo numa mulher de 50 anos, muito bonita e quieta, mas dessas que nem liga pra beleza, mas você a vê, e bem. 0 presente diminui de tamanho nas mãos dela, que te dá, te beija e abraça sem pressa. Você abre, ela desaparece. É um cofre, com sete chaves. Você sabe que ela está lá dentro, agora bem pequenininha, mas nunca vai mostrar pra ninguém. E nunca vai contar sua história de ter vindo de um outro, nem nada disso."
\end{abstract}

"Eu sou sua filha e peço para ficar descalço e entrar num quarto onde tem vários vasos de cristais e um taco de beisebol. Gostaria de entrar neste quarto com você e ver você quebrando todos os vasos e depois me dar um abraço."

A prática dos presentes-cuidadores tem revelado uma textura surpreendentemente funda e expandida (vazada) no espaço de trabalho com as narrativas e dialoga com tudo o que aqui está transmutado em escrita. É uma prática que torna imensa a intimidade, que amplifica o pequeno, e, ao mesmo tempo, insiste na despsicologização desse campo de trabalho para a palavra. Algo que costuma ser feito a partir de uma organização de pensamento (dizer ao outro o que penso de seu trabalho), é dado à vista e à escuta pelo próprio modo do trabalho em si, sem se descolar do que já fazemos no caminho para a palavra escutante. É uma escrita cuidada nascida de uma escuta para cuidar, retornada como pedido de escuta, que cuidará. 


\section{vestígios de uma criação cênica: Peça aos poucos,}

\section{experiências de repouso sobre o texto Timon de Atenas, de William Shakespeare}

Nascido do desejo de colocar teoria e prática em diálogo, em conversa estreita com a pesquisa aqui traduzida, criei junto com alguns parceiros ${ }^{60}$ o projeto artístico acima nomeado, que visava a pôr em cena experiências de repouso sobre o texto Timon de Atenas, sem desejar uma forma espetacular como resultado cênico. Ganhamos, então, o ProAC ${ }^{61}$ para realização desses encontros entre janeiro e setembro de 2009. Enquanto escrevo a conclusão desta tese, a Peça aos poucos acontece em cena. Mas ela já vinha acontecendo como projeto desde junho de 2007. Realizamos, desde abril de 2009, experiências públicas a partir do encontro com o texto de Shakespeare. Este fazer está norteado por:

> Realizar experiências que sejam resultado de estudo nascido da intimidade com o texto.

Cada experiência parte da pessoalidade para chegar à teatralidade.

Partilha constante dos fundamentos de todas as experiências com o público.

> O público como parceiro. A atualidade dos assuntos e das relações.

A escuta como um dos centros fundadores do trabalho.

A não-separação entre teoria e prática dialogando em cena, em presença.

> Ações de trocas com públicos diversos de cinco regiões da cidade de São Paulo (norte, sul, leste, oeste e centro), que realizem, a partir da

\footnotetext{
60 Eram eles: Antônio Januzelli (Janô), Deise Pacheco, Flavia Melman, Renato Theobaldo e Welington Andrade. Os atuais parceiros em desenvolvimento do trabalho são: Deise Pacheco, Flávia Melman, Selma Pellizon, Antônio Januzelli, Caio Paduan, Luiz Pimentel, Otávio Dantas, Claudia Burbulhan, Aldeias Indígenas do Jaraguá e de Parelheiros, Associação Cultural Paidéia, LINCE-Laboratório do Ator, prof. Flávio Desgranges e alunos do $1^{\circ}$ ano (CACECA-USP), Cia. Teatral Ueinzz, Núcleo Vocacional (SMC-São Paulo), Oficina Cultural Oswald de Andrade, Projeto Quixote, Universidade São Judas Tadeu. Até maio de 2009 foram realizadas seis escavações cênicas públicas e uma escavação epistolar.

${ }^{61}$ Prêmio para montagem de peças da Secretaria de Estado da Cultura do Estado de São Paulo.
} 
intimidade, experiências-escavações como alternativas às práticas mais frequentes utilizadas nos programas que tratam da formação de público para arte, tais como: debates, palestras, fóruns etc.

escavar. [do lat. excavare.] 2. Cavar em roda. 3. Tirar terra de; fazer escavação. 5. Fig. Investigar, pesquisar, escarafunchar.

Concebemos essas experiências como questões, ações que se querem realmente instigadoras do fazer teatral e das relações que implicam escavações geradas pelos assuntos do texto. Assuntos também que, esperamos, irão à cena contaminados por todas as experiências realizadas com ele. Normalmente, as criações teatrais - sejam mais longas ou mais curtas em seus tempos de ensaios - entendem que ensaio é uma preparação para uma apresentação, momento no qual algum saber, nascido de qualquer matriz estética, literária ou não, esteja plenamente configurado em cena para se tornar público.

Aqui não há espaço direcionado à constituição de um saber isolado de seu envolvimento público. Pelo contrário, nossa aprendizagem acontece em nome da experiência que nos passa, nos acontece e nos toca justamente nos ENTRE-Nós: nós e o texto, nós e os parceiros, nós e o lugar, nós e a duração, todos (os) nós e o público. Cada encontro acontece para no máximo 50 pessoas.

\section{Escavações cênicas e escavações epistolares}

"Por hora, assinalamos que todo conhecimento da intimidade das coisas é imediatamente um poema." A terra e os devaneios do repouso, Gaston Bachelard

“O público do teatro quer ver a passagem do texto à cena. Ele escava a cena para exumar o texto soterrado (invisível). 0 olhar do espectador é aqui uma estranhíssima abertura para a escuta. Não no sentido de que ele deveria fechar os olhos para ouvir. 0 que o espectador olha é o jogo dos traços imagéticos que atesta a presença aqui, física, corporal, de um texto que 
age na sombra, obscuro, e cuja onipresença é uma espécie de ausência ativa. Por isto as novas encenações de textos clássicos desempenharam várias vezes o papel de manifesto das mudanças de época da teatralidade - porque elas dão a ver, com uma clareza meridiana, o trabalho do texto ausente nos corpos e bocas visíveis." A exibição das palavras: uma idéia (política) do teatro. Denis Guénoun

Realizamos experiências que chamamos gestos aproximadores do texto, ações que consideram sempre o eixo pessoalidade-teatralidade. Entendemos por pessoalidade a revelação pública, por meio do texto, das posições de todos os envolvidos no projeto criadores iniciais e parceiros de todas as experiências, convidados e públicos diversos. A pesquisa em torno da teatralidade quer investigar e traçar, com a parceria do público, o percurso que leva o homem ao 'teatro', aos lugares de exposição e intensidade conscientes característicos do que se chama 'cena'. O ponto de partida do que nomeamos gestos aproximadores é o conhecimento da intimidade para, quem sabe, nossas escavações tornarem-se poema. As escavações cênicas são realizações acontecidas a partir de propostas concretas de ações nossas (equipe, parceiros e público) na relação com o texto.

epístola. 3. Composição poética em forma de carta.

Simultaneamente às escavações cênicas - que totalizarão 26, até setembro de 2009 -, acontecem oito escavações epistolares - em oito das 26 cênicas há leitores das cartas -, gestos aproximadores do texto, realizados por convidados que escreverão cartas cuja propulsão é um exercício a partir da intimidade. Sua fala-escritura da carta partirá de uma leitura de Timon de Atenas e deverá ser endereçada a um destinatário íntimo qualquer (seu filho, sua avó, seu travesseiro, um escritor, algum personagem de ficção, seu cachorro...), ficcional ou não. Aqui queremos brincar com a fala da 
autoridade - os convidados - em determinado assunto (sociologia, literatura, teoria crítica, educação, crítica teatral, economia, dança, teologia, saúde física e mental etc.) aproximada dos "desautorizados", isto é, a fala que se desfaz da especialidade e se refaz em aproximação, desejo de comunicação e encontro. A autoridade lê o texto com o único comprometimento de levar ao público de que fará parte uma carta escrita a um destinatário íntimo que seja tradução de suas questões, impressões, ecos e reverberações na relação com o texto. Não há nenhum pedido de comprometimento teórico em relação ao texto ou ao autor, nem a necessidade de procurar elogiar o texto.

Os vestígios da Peça aos poucos foram trazidos para cá, pois trata-se de um projeto artístico em acontecimento, criado em diálogo muito próximo com o que vem sendo dito nesta escrita, e que vem indicando caminhos do que nasce como prática de formação e preparação, postos em cena como procedimentos aproximadores públicos: para o público e com o público. Ele pode ser parceiro tanto para contemplar como para fazer junto. Sou atriz e co-diretora geral do projeto Peça aos poucos. 


\section{vestígios da escuta de um dizer, que pede para ser mantido em seu elemento}

"A escrita é uma coisa, e o saber, outra. A escrita é a fotografia do saber, mas não o saber em si. O saber é uma luz que existe no homem. A herança de tudo aquilo que nossos ancestrais vieram a conhecer e que se encontra latente em tudo o que nos transmitiram, assim como o baobá já existe em potencial em sua semente." (BÂ, s/d, p.181)

O etnólogo malinês Amadou Hampâté Bâ abre o texto "A tradição viva", em A história geral da África, assim:

Quando falamos de tradição em relação à história africana, referimo-nos à tradição oral, e nenhuma tentativa de penetrar a história e o espírito dos povos africanos terá validade a menos que se apóie nessa herança de conhecimentos de toda espécie, pacientemente transmitidos de boca a ouvido, de mestre a discípulo, ao longo dos séculos. Essa herança ainda não se perdeu e reside na memória da última geração de grandes depositários, de quem se pode dizer que são a memória viva da África. (BÂ, s/d, p.181)

Não sou africana, nem este trabalho jamais pretendeu penetrar a história africana, nem Sotigui Kouyaté é meu mestre, nem tampouco sou grande depositária de nada. Mas tenho memória; afinal, nosso corpo é memória.

O movimento para transformar meus interesses, minha prática e parte do que tem me ocupado em um doutorado nasceu da experiência relatada na página 47, a partir de um solo de escuta vivenciado com uma profundidade que me era nova, por sua simplicidade, pela ausência de esforço, pela força-calma do encontro entre corpo e dizer, pela não separação entre as coisas acontecidas ali. Este é o caminho que o encontro com Sotigui vem abrindo. E ele tem se dado sempre no terreno da oralidade e da experiência viva. Comecei este doutorado com o desejo de me dedicar a traduzir todas as práticas vivenciadas com ou a partir de alguma mediação de Sotigui Kouyaté ${ }^{62}$,

\footnotetext{
${ }^{62}$ Ver BERNAT, 2008.
} 
em diálogo com as minhas experiências, mas somente as que fossem dedicadas ao ator como narrador, em um projeto de pesquisa que se chamava A palavra viva. Muita coisa mudou desde então. Houve mais três estágios com ele, mais uma viagem para o Burkina Faso, parte dela com Sotigui e parte dela sem ele, muitos outros trabalhos realizados dentro e fora de cena -, encontros com outras pessoas, aprofundamentos das práticas em diálogos com meus parceiros.

Nando Bolognesi, amigo, ator e palhaço, durante o estágio coordenado por Sotigui no SESC Consolação (SP), em 2006, disse-me ao final:

\footnotetext{
"Saí daqui muito bravo depois do primeiro dia. Esse homem fala de escuta, de escuta, mas ele só fala, ele fala pra caramba. E só ele fala, ele não me escuta! Depois do segundo dia percebi o que ele trabalha. Eu comecei a me escutar mais porque eu estava quieto. Escutando-o eu me escutava e me voltava para mim."
}

Talvez o movimento que tenha acontecido nestes 4 anos e meio de experiência 'formalizada' como doutorado - falo de um nome, de um espaço interno ocupado por este nome 'doutorado', e de todos os diálogos daí derivados - seja o de retornar a mim. E entender tanto essa aproximação de mim mesma como as pessoas de minha pessoa como visitantes desse receptáculo que venho sendo, como abridores dos caminhos para que outras minhas pessoas se apresentem a mim e vice-versa: que o encontro comigo também apresente às pessoas dos outros as suas outras pessoas até então desconhecidas. 
“O outro não existe: está é a fé racional, a crença incurável da razão humana. Identidade $=$ realidade, como se, afinal de contas, tudo tivesse de ser, absoluta e necessariamente um e o mesmo. Mas o outro não se deixa eliminar; subsiste, persiste; é o osso duro de roer onde a razão perde os dentes. Abel Martín, com fé poética, não menos humana que a fé racional, acreditava no outro, na "essencial heterogeneidade do ser", como se disséssemos na incurável outridade que o um padece." (MACHADO, Antonio. Apud PAZ, 1984, p. 7)

Em todos os estágios Sotigui fala para os participantes sobre a noção de pessoa em sua tradição. Na tradição bambara, dois termos servem para designar a pessoa: Maa e Maaya (pronuncia-se algo como 'mogó’ e mogoiá’). As primeiras palavras significam “a Pessoa” e, as segundas, "as pessoas da pessoa”. A tradição ensina que existe antes Maa, a "Pessoa receptáculo", e depois Maaya, ou seja, os diversos aspectos de Maa contidos no Maa-receptáculo. Como diz a expressão bambara Maa ka Maaya ka ca a yere kono: “As pessoas da pessoa são múltiplas na pessoa." A mesma noção acontece entre os fulas. É uma noção complexa que implica

uma multiplicidade interior de planos de existência concêntricos e superpostos (físicos, psíquicos e espirituais, em diferentes níveis), bem como uma dinâmica constante. (BÂ, 1972, p. 5)

Sotigui revela em trabalho uma imensa disponibilidade para o outro. Para qualquer outro, incluindo o outro que se mostra inoportuno, inadequado, inconveniente. "Só conhecemos as pessoas de nossa pessoa", diz ele, "no encontro com o outro. É o encontro com o outro que nos apresenta quem somos. E nunca o saberemos se não estivermos em real contato com o outro." Estar em contato com o outro, em sua tradição, é dispor-se a partir do aberto. Segundo revelou repetidas vezes, o povo malinquê considera a mulher mais inteligente que o homem, pois ela tem mais buracos 
em seu corpo e a potência natural para a amamentação ainda dá mais dois buracos (seios) de relação entre dentro e fora de si. Mais buracos, maior inteligência, pois maior possibilidade de relacionar-se. A lembrança quer registrar a curiosa relação espaços abertos = maior inteligência

Mas nós não estamos no campo da oralidade. Ela ocupa parte deste campo, mas aqui o ator vê a palavra, parte de textos lidos. "Mirar significa adentrar o silêncio", lembra Heidegger ${ }^{63}$. 0 que meu 'mirar a oralidade' tem me ensinado? Tudo o que aqui se traduz. Se é que alguma lealdade ao campo da prática pode ser traduzida. Não sei. Quem me dirá é o outro. Aquele que (me) lê.

Mas vejo, com Sotigui, que o ator que se dispõe a partir de uma escuta, ao ver a palavra enquanto lê, adentra o silêncio. E mantém suavidade em seu transitar para o dito, para o dizer, pois já experiencia dizer sempre desde esta escuta. "A palavra suave significa reunir pacificamente." O ator reúne perto de si o que vê, o que lê. Presente na presença, perto de si, sua escuta escuta o quieto. Ao co-responder o texto, ao dizê-lo, ele escuta. “Corresponder é escutar. Ele escuta à medida que pertence ao chamado da quietude."

Em meu percurso, tenho procurado escutar o que se escuta em mim a partir do encontro com Sotigui. E passei a não desejar mais traduzir nada, informar nada, explicar nada sobre o que vem dali, do lugar-Sotigui aberto em mim. Mas continuo a contar alguns fragmentos desse encontro para que você possa escutar as conexões que permanecerão segredadas.

\footnotetext{
${ }^{63}$ Os dois parágrafos citam entre aspas trechos de HEIDEGGER, 2003.
} 
Numa tarde de 2004, assistíamos a um vídeo para ser escolhido para o estágio que ele daria em São Paulo naquela semana no Teatro Fábrica. As imagens eram registros de um ritual acontecido em um campo de iniciação, diferente do seu, segundo ele me disse naquele momento. Um homem vestido de mulher mantém seus braços levantados, com as axilas à mostra. Outro homem se aproxima e bate em suas axilas com uma vara fina. O homem que apanha sorri exatamente no momento em que apanha. Ri de sua dor. Sotigui então me diz algo próximo disto: “Em todos os campos há rituais assim; sempre temos que rir no sofrimento, do sofrimento, nos divertindo com ele, ao mesmo tempo. As coisas não estão separadas."

Durante a conferência que realizou no Teatro da Aliança Francesa, em São Paulo, em 2003, uma atriz perguntou da platéia a Sotigui:

"Na peça Hamlet, dirigida por Peter Brook, que veio para São Paulo em 2002, você é muito diferente de todos os outros atores em cena. 0 que é isso? O que você acha que é diferente?"

Ele respondeu:

“É você quem poderia dizer o que eu tenho de diferente, mas eu vou te contar uma história. ${ }^{64}$ Minha mãe cantava uma canção para mim desde os meus 5 anos. A canção diz: ' $O$ sério não está separado da brincadeira e a brincadeira não está separada do sério.' É assim que é entre nós. Eu me lembro dessa canção todos os dias da minha vida. Todos os dias, quando acordo, me lembro de quando eu tinha 5 anos."

$\mathrm{E}$, todavia, para o homem é a proximidade o que lhe está mais distante." (HEIDEGGER, 1995, p.51)

${ }^{64}$ Ele é um tagarela. 
Os griots (dieli em bambara ${ }^{65}$ )

gozam de grande liberdade de falar. Podem manifestar-se à vontade, até mesmo impudentemente e, às vezes, chegam a troçar das coisas sagradas sem que isso acarrete graves conseqüências. Não têm compromisso algum que os obrigue as ser discretos ou a guardar respeito absoluto para com a verdade. Podem às vezes contar mentiras descaradas e ninguém os tomará no sentido próprio. (...) têm a boca rasgada. 0 nome dieli em bambara significa sangue. (BÂ, s/d, p.204)

Ao ser visitada por Sotigui - um homem que visita constantemente seu próprio sangue, sua origem - e por todas as infindáveis histórias que ele conta e todas as que repete sem cessar - algumas já ouvi mais de dez vezes, e ele as reconta sempre de um mesmo modo, sem medo algum da repetição -, fui chamada a visitar o meu sangue, a minha carne e alguma corporeidade de meus encontros com as pessoas, intermediados por isto que vem sendo chamado teatro. Junto a este repouso sobre o meu traço, percebi que gostaria de manter o que vem de nossa aliança guardado (preservado) em seu elemento, o elemento da transmissão oral. Não sei o que veio antes. Mas preferi escutar o aceno.

$\mathrm{Na}$ tradição de Sotigui a palavra teatro não existe. A origem da palavra para nomear teatro na África Ocidental é outra. A palavra grega, nascida do verbo ver e fixada como 'lugar de onde se vê', para nomear o que chamamos teatro não existe. Quando, na Itália, Sotigui Kouyaté escutou um diretor teatral afirmar que na África não existia teatro, respondeu:

\footnotetext{
"Entre nós realmente não existe essa palavra de origem grega que vocês usam em diversas línguas: teatro. Nos países da África Ocidental Guiné, Mali e Burkina Faso -, de onde venho, temos três palavras diferentes para nomear isso. Uma delas quer dizer 'conhecermo-nos'. A
}

\footnotetext{
${ }^{65}$ Língua mais falada pelo povo malinquê.
} 
outra quer dizer 'caracol', que se refere à disposição em que as pessoas ficam para participar como público, um círculo de crianças, outro de mulheres e outro de homens. Lá, fazemos sempre para todos, ao mesmo tempo. A terceira palavra usamos para dizer 'vamos ao teatro'. Dizemos: 'vou clarear minha visão'. É isso que temos na África. Não se pode dizer que entre nós não há teatro."

O nome Kouyaté significa: existe um segredo entre mim e você.

Mas esta escrita ainda quer dar-a-ler a você algum segredo.

Alguma oralidade fez nascer esta escrita. Algumas leituras fizeram nascer esta escrita. Algumas experiências fizeram nascer esta escrita. Alguns encontros fizeram nascer esta escrita. Ainda não sei que pessoa acordará aqui amanhã, ao ter colocado aqui um ponto final. Mas algo sabe em mim muito diferente do que vinha sabendo até chegar aqui. Muito diferente. Não sei se isso tem este nome: saber. Sei que conheci um novo sentido para a palavra dor e para a palavra graça. Escavando-as, usando essas quase 40 mil palavras como pá, adentrando em muitos escuros com algumas luzes, lanternas, holofotes, com os cuidados de todos os que disso cuidaram comigo (e o sabem), vi que não tem tanto mistério assim a existência na dor e na graça. $O$ único problema é que as palavras simples são as mais difíceis de escutar, como li um dia no livro de um amigo distante. E a criança é muito concreta em sua simplicidade, naquilo que ela dá a ser visto porque, simplesmente, nasce. Se minha linguagem aqui ainda é criança, se ela não consegue crescer, tornar-se ciência, é porque ela não conseguiu ser outra coisa. Não se destinou a isso. A insistência da primeira e mais próxima leitora deste texto sempre foi para que eu me mantivesse presente, próxima daqui. Algo em mim sempre perguntava se poderia fazê-lo num espaço destinado ao saber científico, a academia. Mas essa pergunta era engano, disfarce. Pois do outro modo, o que eu ensaiava escrever não era nada, era palavra anestesiada, distante. Assumir as 
alianças, minha falta de filiação, de pensamento causal, tudo nasceu de rigor vindo de fora. Eu poderia fingir. Como o ator. Fingir ser outro. Mas aqui não é cena, não é teatro. Mais: aqui não é jogo. Aqui é repouso o que se pede. Ele ainda não mora aqui, o repouso. Mas é norte para o meu mapa a partir daqui.

Eu espero. E agradeço.

A pureza do leitor (mesmo se ele não lê nenhum livro): ninguém é mais puro a meus olhos Peter Handke, À ma fenêtre le matin 


\section{Referências bibliográficas}

ABREU, Luís Alberto de. "A restauração da narrativa”. In: O percevejo, Rio de Janeiro, ano 8, n. 9, 2000.

ARTAUD, Antonin. Linguagem e vida. São Paulo: Perspectiva, 1995. . O teatro e seu duplo. São Paulo: Max Limonad, 1984.

ASLAN, Odette. Les Corps en Jeu. Paris: CNRS, 2003. . O ator no século XX - Evolução da técnica/Problema da ética.

São Paulo: Perspectiva, 1994.

BÂ, Amadou Hampatê. Amkoullel, o menino fula. São Paulo: Palas Athena: Casa das Áfricas, 2003.

"A noção de pessoa entre os fula e os bambara". In: Aspects de la Civilization Africaine, Paris: Présence Africaine, 1972.

Unesco/Ática, s/d.

. “A tradição viva”. In: História Geral da África.

. Vie et Enseignement de Tierno Bokar, le Sage de

Bandiagara. Paris: Éditions du Seuil, 1980.

BACHELARD, Gaston. A poética do espaço. São Paulo: Martins Fontes, 1993. A terra e os devaneios do repouso. São Paulo: Martins

Fontes, 1995.

BAJARD, Elie. Ler e dizer, compreensão e comunicação do texto escrito. São

Paulo: Cortez, 2005.

BANU, Georges. L'Homme de Dos. Peinture, Théâtre. Paris: Adam Biro, 2001.

BARTHES, Roland. Aula. São Paulo: Cultrix, s/d.

. A câmara clara. Rio de Janeiro: Nova Fronteira, 1984.

BASHÔ, Matsuo. Sendas de Ôku, São Paulo: Roswitha Kempf, 1986.

BENE, Carmelo e DELEUZE, Gilles. Superpositions: Richard III suivi de Un Manifeste de Moins. Paris: Minuit, 1979.

BENJAMIN, Walter. "Experiência e pobreza”. In: Magia e técnica, arte e política. São Paulo: Brasiliense, 1976.

- “O narrador”. In: Magia e técnica, arte e política. São Paulo:

Brasiliense, 1976.

BRETON, David Le. Do silêncio. Lisboa: Instituto Piaget, s/d.

BROOK, Peter. A porta aberta. Reflexões sobre a interpretação e o teatro.

Rio de Janeiro: Civilização Brasileira, 1994a

. Entre Deux Silences. Paris: Actes-Sud, 2006.

"Grotowski, arte como veículo." Tradução por Marcelo Gonzales.

Conferência proferida em Florença, março de 1987.

- O diabo é o aborrecimento. Conversas sobre teatro. Porto: Edições Asa,

1993.

O ponto de mudança: quarenta anos de experiências teatrais:

1946-1987. Rio de Janeiro: Civilização Brasileira, 1994b.

. O teatro e seu espaço. Petrópolis: Vozes, 1970.

. Threads of Time. A Memoir. London: Methuen, 1998.

CAGE, John. De segunda a um ano. São Paulo: Hucitec, 1985.

Silence. Conferénce et Écrits. Genève: Éditions Héros-Limite, 2003.

CALVINO, Italo. Seis propostas para o próximo milênio: lições americanas.

São Paulo: Cia. das Letras, 1990.

CAMARA, Sory. Gens de la Parole, Essai sur la Condition et le Role des Griots dans la

Société Malinké. Paris: ACCT, Karthala, SAEC, 1992.

. Paroles Très Anciennes. Grenoble: La Pensée Sauvage, 1982.

CARVALHO, Enio. História e formação do ator. São Paulo: Ática, 1989. 
CASTELLO, Luis A. e MÁRSICO, Claudia T. Oculto nas palavras: dicionário etimológico para ensinar e aprender. Belo Horizonte: Autêntica, 2007.

CLARK, Lygia. “O vazio-pleno”. Jornal do Brasil, Rio de Janeiro, 2 abril de 1960. Suplemento Dominical, p. 5.

DERRIDA, Jacques. A escritura e a diferença. São Paulo: Perspectiva, 2005. A voz e o fenômeno: introdução ao problema do signo na fenomenologia de Husserl. Rio de Janeiro: Jorge Zahar, 1994. Margens da filosofia. Campinas: Papirus, 1991.

DIABATÉ, Massa Makan. Le Boucher de Kouta. Paris: Éditions Hatier, International, 2002.

2002. Le Coiffeur de Kouta. Paris: Éditions Hatier, International, 2002.

DORT, Bernard. Théâtre en Jeu: 1970-1978. Paris: Éditions du Seuil, 1979.

FERREIRA, Aurélio Buarque de Holanda e J.E.M.M. Editores Ltda. Novo dicionário da língua portuguesa. Rio de Janeiro: Nova Fronteira, 1986.

GARCIA, Hamilcar de. Dicionário de português-espanhol, espanhol-português. São Paulo: Globo, 1998.

GREINER, Christine. O corpo: pistas para estudos indisciplinares. São Paulo: Annablume, 2005.

GROTOWSKI, Jerzy. Em busca de um teatro pobre. Rio de Janeiro: Civilização Brasileira, 1987.

- El Performer. Máscara: Cuaderno Iberoamericano de Reflexión sobre Escenologia. Ano 3, $\mathrm{n}^{\text {os }}$ 11-12, outubro de 1992. Almagesto, 1992. ¿Qué Significa la Palabra "Teatro"?. Buenos Aires:

GUÉNOUN, Denis. A exibição das palavras. Uma idéia (política) do teatro. Rio de Janeiro: Teatro do Pequeno Gesto, 2003. - O teatro é necessário? São Paulo: Perspectiva, 2004.

HANDKE, Peter. Poème à la Durée. Paris: Gallimard, 1987.

HEIDEGGER, Martin. A caminho da linguagem. São Paulo: Vozes, 2003. . Carta sobre o humanismo. Rio de Janeiro: Tempo Brasileiro, 1995. . Ensaios e conferências. Petrópolis: Vozes, 2006.

HERRIGEL, Eugen. A arte cavalheiresca do arqueiro zen. São Paulo: Pensamento, s/d.

HOUAISS, Antônio e VILLAR, Mauro de Salles. Dicionário Houaiss da língua portuguesa. Rio de Janeiro: Objetiva, 2001.

I Ching. O livro das mutações. São Paulo: Pensamento, s/d.

JODOROWSKI, Alejandro e MOEBIUS. Os olhos do gato. São Paulo: Martins Fontes, 1987.

Langenscheidt, Dicionário de bolso das Línguas Portuguesa e Alemã. Berlim: Langenscheidt, 1982.

LAOZI. Dao De Jing. São Paulo: Hedra, 2002.

LARROSA, Jorge. "Dar a ler... talvez". In: Linguagem e educação depois de Babel. Belo Horizonte: Autêntica, 2004.

. "Sobre a lição ou do ensinar e do aprender na amizade e na liberdade". In: Pedagogia profana. Lisboa: Autêntica, 2003.

MORIN, Edgar. A cabeça bem-feita: repensar a reforma, reformar o pensamento. Rio de Janeiro: Bertrand Brasil, 2000.

A inteligência da complexidade. São Paulo: Peirópolis, 2000. 
. Amor, poesia, sabedoria. Rio de Janeiro: Bertrand Brasil, s/d.

Ciência com consciência. Rio de Janeiro: Bertrand Brasil, 1996.

N'DA K, P. Le Conte Africain et l'Éducation. Paris: L'Harmattan, 1984.

NOVALIS. Pólen: fragmentos, diálogos, monólogo. Tradução, apresentação e notas de Rubens Rodrigues Torres Filho. São Paulo: lluminuras, 1988.

OHNO, Kazuo e OHNO, Yoshito. Kazuo Ohno's World. From Without and Within. Connecticut: Wesleyan, 1997.

OIDA, Yoshi. An Actor's Tricks. London: Methuen, 2007.

. O ator invisível. São Paulo: Beca, 2000.

Um ator errante. São Paulo: Beca, 2001.

PAVIS, Patrice. Dicionário de teatro. São Paulo: Perspectiva, 1999.

PAZ, Octavio. "A tradição do haiku”. In: BASHÔ, Matsuo. Sendas de Ôku. São

Paulo: Roswitha Kempf, 1986.

. "A poesia de Matsuo Bashô". In: BASHÔ, Matsuo. Sendas de Ôku. São Paulo: Roswitha Kempf, 1986.

PELBART, Peter Pál. Vida capital, ensaios de biopolítica. São Paulo, Iluminuras, 2003.

PESSANHA, Juliano Garcia. "Natalidade e crise no tempo antropológico". In: Certeza do agora. São Paulo: Ateliê, 2002.

"Província da escritura". In: Certeza do agora. São Paulo: Ateliê, 2002. 0 trem, o entre e o Paradiso terrestre (texto fotocopiado).

PEREIRA, Isidro. Dicionário grego-português e português-grego. Braga: Livraria Apostolado da Imprensa, 1998.

QUILICI, Cassiano Sydow. Antonin Artaud. Teatro e ritual. São Paulo: Annablume/Fapesp, 2004.

ECA-USP, 2005.

ROSA, João Guimarães. Grande sertão: veredas. Rio de Janeiro: José Olympio, 1963.

ROSENFELD, Anatol. O teatro épico. São Paulo: Perspectiva, 1985.

SALINGER, Jerome David. "Um dia ideal para os peixes-banana". In: Nove histórias. Rio de Janeiro: Editora do Autor, 1969.

Autor, 1965.

SARAIVA, F. R. dos Santos. Novíssimo dicionário latino-português. Rio de Janeiro: Livraria Garnier, 1993.

SARRAZAC, Jean-Pierre. Critique du Théâtre. Belfort: Circé, 2000. O futuro do drama. Porto: Campo das Letras, 2000. La Parabole ou l'Enfance du Théâtre. Colin, Paris, 2001.

SAVATER, Fernando. A infância recuperada. São Paulo: Martins Fontes, 2001.

SCHECHNER, Richard. Performance Studies: an Introduction. London: Routledge, 2003.

SOMÉ, Sobonfu. O espírito da intimidade. São Paulo: Odysseus, 2003.

STAMM, Anne. La Parole Est un Monde. Paris: Éditions du Seuil, 1999.

STANISLAVSKI, Constantin. A construção da personagem. Rio de Janeiro: Civilização Brasileira, 1989.

A preparação do ator. Rio de Janeiro: Civilização Brasileira, 1986.

ZUMTHOR, Paul. Escritura e nomadismo: entrevistas e ensaios. São Paulo: Ateliê, 2005. . Performance, recepção, leitura. São Paulo: EDUC, 2000.

\section{Pesquisas}

BARBOZA, Juliana Jardim e JANUZELLI, Antonio. Procedimentos metodológicos do trabalho do ator de teatro: primeiras investigações. 
São Paulo: LINCE-ECA-USP, 1999-2000.

BARBOZA, Juliana Jardim. $O$ ator transparente: o treinamento contemporâneo com as Máscaras do Palhaço e do Bufão e a experiência de uma peça: Madrugada. São Paulo, CAC-ECA-USP, 2001.

BERNAT, Isaac. $O$ olhar do griot sobre o ofício do ator. Reflexões a partir dos encontros com Sotigui Kouyaté. Tese de doutorado, UniRio, Rio de Janeiro, 2008.

PUPO, Maria Lúcia. Palavras em jogo. Tese de livre-docência, CAC-ECA, USP, São Paulo, 1997.

Filmes, vídeos

Peter Brook, au tour de L'Espace Vide. Trois films de Jean-Gabriel Carasso e Mohamed Charbaoi. Paris: ANRAT, Association Nationale de Recherche el d'Action Théâtrale.

Sotigui Kouyaté, un griot moderne. Direção de Mahamat Saleh Haroun, France: Le Production de La Lantherne, 1997.

Afrique, compilação de documentários amadores doada por Sotigui Kouyaté.

Keyta, l'Héritage du griot. Direção de Dany Kouyaté.

Amadou Hampâté Bâ, entrevista para a televisão francesa.

Sotigui Kouyaté, um griot no Brasil. São Paulo: SESC TV, 2007. 
“A verdadeira forma surge apenas no último momento, às vezes mesmo para além do último momento. É um nascimento. A verdadeira forma não é como a construção de um edifício, a sequiência de uma série de ações construtivas e lógicas. Pelo contrário, o verdadeiro processo de construção é ao mesmo tempo uma espécie de destruição. Isso quer dizer que nos encaminhamos cada vez mais para o medo, como qualquer destruição. Criamos um vazio, temos menos muletas, menos apoios, estamos cada vez mais em perigo." (BROOK, 1993, p. 32) 